Otimizando o teste estrutural de programas concorrentes: uma abordagem determinística e paralela 



\title{
Otimizando o teste estrutural de programas concorrentes: uma abordagem determinística e paralela
}

\author{
Raphael Negrisoli Batista
}

Orientador: Prof. Dr. Paulo Sérgio Lopes de Souza

Dissertação apresentada ao Instituto de Ciências Matemáticas e de Computação - ICMC-USP, como parte dos requisitos para obtenção do título de Mestre em Ciências - Ciências de Computação e Matemática Computacional. VERSÃO REVISADA 
Ficha catalográfica elaborada pela Biblioteca Prof. Achille Bassi e Seção Técnica de Informática, ICMC/USP, com os dados fornecidos pelo(a) autor(a)

Batista, Raphael Negrisoli

Otimizando o teste estrutural de programas concorrentes: uma abordagem deterministica e paralela / Raphael Negrisoli Batista; orientador Paulo Sérgio Lopes de Souza. -- São Carlos, 2015. $92 \mathrm{p}$.

Dissertação (Mestrado - Programa de Pós-Graduação em Ciências de Computação e Matemática Computacional) -- Instituto de Ciências Matemáticas e de Computação, Universidade de São Paulo, 2015.

1. teste estrutural. 2. programas concorrentes. 3. execução determinística. 4. geração de variantes de disputa. 5. execução paralela. I. Souza, Paulo Sérgio Lopes de, orient. II. Título. 
Defeitos não fazem mal, quando há vontade e poder de os corrigir.

Machado de Assis 

À Mairis, Maria Inez, José Sérgio e Daniel. 



\section{Agradecimentos}

Agradeço primeiramente a Deus por permitir que esse trabalho fosse possível, dando-me saúde e todas as condições necessárias para concluir este projeto.

Gostaria de agradecer ao meu orientador, Prof. Dr. Paulo Sérgio Lopes de Souza. Sem suas orientações e paciência, este projeto não seria possível. Agradeço por toda sua contribuição, no que cabe a este projeto e na minha formação pessoal. Também agradeço à Profa. Dra. Simone do Rocio Senger de Souza por todo seu apoio durante este projeto.

Gostaria de agradecer aos meus pais Maria Inês e José Sergio. Palavras não podem expressar o amor e respeito que sinto por vocês. Tudo que é bom em mim devo a vocês. Também agradeço ao meu irmão Daniel pelo apoio e incentivo.

À minha noiva Mairis, que suportou toda a distância e me apoiou incondicionalmente durante estes três anos. Obrigado por compreender minha ausência e por todas as palavras e gestos que me incentivaram a concluir este projeto.

Aos amigos Denis e Luis pela amizade, companheirismo e por todas as discussões durante o projeto. O caminho teria sido ainda mais árduo sem a presença de vocês.

A todos os amigos do grupo TestPar, em especial ao Rafael, George, Murilo e Alexandre. Obrigado pelas discussões e por toda a ajuda. Também gostaria de agradecer o George por toda a hospitalidade, pela companhia durante os finais de semana no LaSDPC e por toda a ajuda com os benchmarks.

A todos aos amigos do LaSDPC e LABES que contribuíram durantes os seminários e discussões para tornar este projeto ainda melhor.

Aos amigos Nowaki, Rodolfo e Polido pelo apoio e incentivo.

Por fim, agradeço o apoio financeiro da Fundação de Amparo à Pesquisa do Estado de São Paulo (FAPESP) sob processo $n^{o}$ 2012/14285-4 e também pelo apoio financeiro da CAPES. 

teste de programas concorrentes é uma atividade custosa devido principalmente à quantidade de sequências de sincronização que devem ser testadas para validar tais programas. Uma das técnicas mais utilizadas para testar a comunicação e sincronização de programas concorrentes é a geração automática de diferentes pares de sincronização ou, em outras palavras, a geração de variantes de disputa (race variant). Nesta técnica as variantes de disputa são geradas a partir de arquivos de rastro de uma execução não-determinística e algoritmos de execução determinística são utilizados para forçar que diferentes sincronizações sejam cobertas. Este trabalho aborda de maneira abrangente este problema, cujo objetivo principal é reduzir o tempo de resposta da atividade de teste estrutural de programas concorrentes quando diferentes variantes de disputa são executadas. Há três principais contribuições neste trabalho: (1) geração de arquivos de rastro e execução determinística total/parcial, (2) geração automática de variantes e (3) paralelização da execução das variantes. Diferentemente de outros trabalhos disponíveis na literatura, os algoritmos propostos consideram programas concorrentes que interagem simultaneamente com passagem de mensagens e memória compartilhada. Foram consideradas seis primitivas com semânticas distintas: ponto-a-ponto bloqueante/não bloqueante, coletivas um-para-todos/todos-para-um/todos-para-todos e semáforos. Os algoritmos foram desenvolvidos no nível de aplicação em Java, são ortogonais à linguagem de programação utilizada e não requerem privilégios de sistema para serem executados. Estas três contribuições são descritas, detalhando seus algoritmos. Também são apresentados os resultados obtidos com os experimentos feitos durante as fases de validação e avaliação de cada contribuição. Os resultados demonstram que os objetivos propostos foram atingidos com sucesso para cada contribuição e, do ponto de vista do testador, o tempo de resposta da atividade de teste estrutural de programas concorrentes foi reduzido enquanto a cobertura de programas concorrentes com ambos os paradigmas aumentou com procedimentos automatizados e transparentes. Os experimentos mostram speedups próximos ao linear, quando comparadas as versões sequencial e paralela dos algoritmos. 

HE testing of concurrent programs is an expensive task, mainly because it needs to test a high number of synchronization sequences, in order to validate such programs. One of the most used techniques to test communication and synchronization of concurrent programs is the automatic generation of different synchronizations pairs (or generation of race variants). Race variants are generated from the trace files of a nondeterministic execution, and the deterministic executions force the coverage of different synchronizations. This work approaches this problem in a more general way. It reduces the response time of the structural testing of concurrent programs when different variants are required. There are three main contributions in this work: the generation of trace files and the total or partial deterministic execution, the automatic generation of race variants and the parallelization of execution of race variants. The proposed algorithms take into account concurrent programs that interact simultaneously with message passing and shared memory, including six primitives with distinct semantics: blocking and non-blocking point-to-point, all-to-all/one-to-all/all-toone collectives and shared memory. The algorithms have been implemented in Java in the application level, they are language independent and do not need system privileges to execute. Results obtained during the validation and evaluation phase are also presented and they show that the proposed objectives are reached with success. From the tester viewpoint, the response time of structural testing of concurrent programs was reduced, while the coverage of the concurrent programs with both paradigms increased with automatic and transparent procedures. The experiments showed speedups close to linear, when comparing the sequential and parallel versions. 

Resumo

$\begin{array}{lll}\text { Abstract } & \text { iii }\end{array}$

1 Introdução $\quad 1$

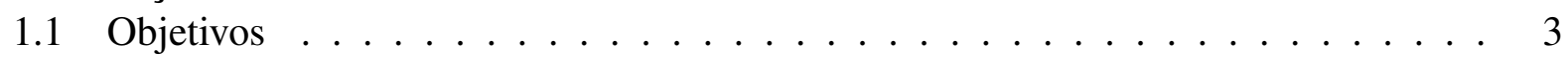

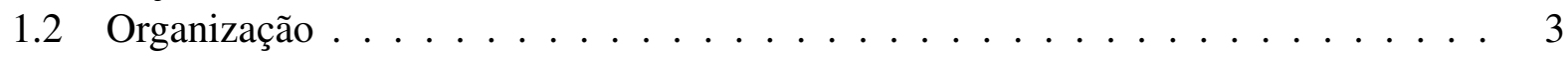

2 Programação Concorrente $\quad 5$

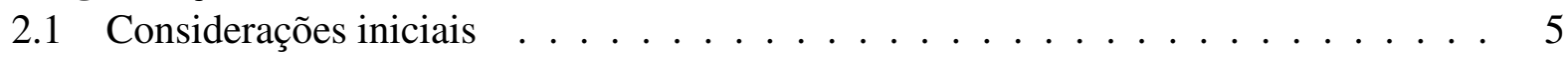

2.2 Conceitos básicos e terminologia . . . . . . . . . . . . . . . 5

2.3 Arquitetura de computadores paralelos . . . . . . . . . . . . . . 8

2.4 Software Paralelo . . . . . . . . . . . . . . . . . . . . . . . . . . . . . . . . . .

2.5 Considerações finais . . . . . . . . . . . . . . . . 13

3 Teste de Software $\quad 15$

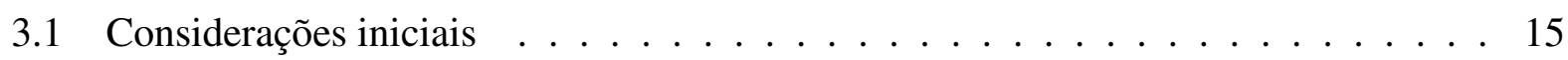

3.2 Conceitos básicos e terminologia . . . . . . . . . . . . . . 15

3.2 .1 Teste estrutural . . . . . . . . . . . . . . . . . . . 18

3.3 Teste estrutural de programas concorrentes . . . . . . . . . . . . . . . 21

3.4 Trabalhos relacionados a teste de programas concorrentes . . . . . . . . . . 25

3.5 Considerações finais . . . . . . . . . . . . . . . . 27

4 Geração de Arquivos de Rastro e Execução Determinística para Programas Concorrentes $\quad 29$

4.1 Considerações iniciais . . . . . . . . . . . . . . . . . . . . . . 29

4.2 A re-execução de um programa concorrente . . . . . . . . . . . . . . . . 30

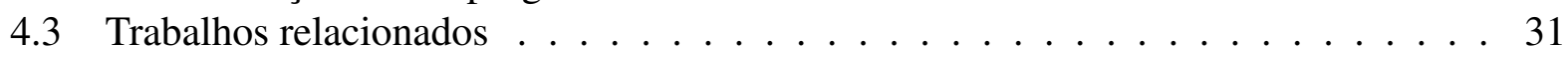

4.4 Algoritmos para geração de rastro e execução determinística . . . . . . . . . . . . . 33

4.4 .1 Geração de arquivos de rastro . . . . . . . . . . . . . . . . . . 34

4.4.2 Execução determinística . . . . . . . . . . . . . . . . . 41

4.5 Avaliação e análise dos resultados . . . . . . . . . . . . . . . . . . . 44

4.6 Considerações finais . . . . . . . . . . . . . . . . . . . 49 
5 Geração Automática de Pares de Sincronização 51

5.1 Considerações iniciais . . . . . . . . . . . . . . . . . 51

5.2 A geração automática de pares de sincronização . . . . . . . . . . . . . . . . 51

5.3 Algoritmos para a geração de variantes . . . . . . . . . . . . . . . . . . . . . . . . . . . . . . 65

5.4 Avaliação e análise dos resultados . . . . . . . . . . . . . . . . 61

5.5 Considerações finais . . . . . . . . . . . . . . . . . . . 64

6 Execução Paralela da Geração Automática de Pares de Sincronização 67

6.1 Consideracões iniciais . . . . . . . . . . . . . . . . . 67

6.2 O custo do teste de programas concorrentes . . . . . . . . . . . . . . . 67

6.3 Darch - uma arquitetura distribuída para o teste de programas concorrentes . . . . . 69

6.4 Paralelização da geração de pares de sincronização . . . . . . . . . . . . . . 71

6.5 Experimentos e resultados . . . . . . . . . . . . . . . . . . 74

6.6 Considerações finais . . . . . . . . . . . . . . . . . 80

7 Conclusões $\quad \mathbf{8 1}$

7.1 Considerações iniciais . . . . . . . . . . . . . . . . . 81

7.2 Discussão dos resultados . . . . . . . . . . . . . . . . . 81

7.3 Contribuições e limitações . . . . . . . . . . . . . . . . 83

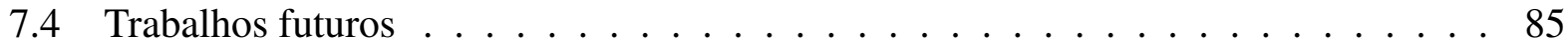




\section{Lista de Figuras}

2.1 Organização de computadores paralelos. . . . . . . . . . . . . . . . . . . 9

3.1 Exemplo de um grafo Def-Uso. . . . . . . . . . . . . . . . . . . . 20

3.2 Exemplo de uma situação onde pode ocorrer um deadlock. . . . . . . . . . . . . . . 22

3.3 Exemplo de um PCFG. . . . . . . . . . . . . . . . . . . . . . . . 23

3.4 Arquitetura da ValiMPI. . . . . . . . . . . . . . . . . . . . . . . . 24

3.5 Arquitetura da ValiPar. . . . . . . . . . . . . . . 26

4.1 As duas fases da execução determinística. . . . . . . . . . . . . . . . . 31

4.2 Diagrama espaço-tempo de um programa de passagem de mensagem bloqueante. . 37

4.3 Tempo médio de resposta das execuções livre e determinística para os benchmarks. 48

4.4 Tamanho do rastro em relação a quantidade de primitivas e quantidade de linhas de código. . . . . . . . . . . . . . . . . . . . . . . . 4 49

5.1 Diagrama espaço-tempo de um programa concorrente com passagem de mensagem e suas possíveis sincronizações. . . . . . . . . . . . . . . . 52

5.2 Exemplo da limitação da política de escolha de novos transmissores, considerando apenas pares ainda não cobertos. . . . . . . . . . . . . 58

5.3 Processo de geração de variantes e organização das variantes. . . . . . . . . . . . . . 61

5.4 Gráfico comparativo do número de variantes geradas em relação à política de seleção de transmissores. . . . . . . . . . . . . . . . . . . . . . 63

6.1 Fluxo da arquitetura durante a transmissão de uma mensagem considerando dois

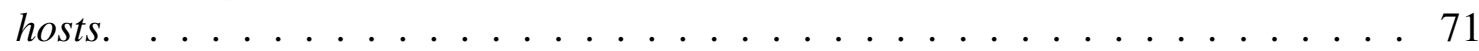

6.2 Tempo de resposta médio da sessão de teste em relação à quantidade de nós para os três benchmarks. . . . . . . . . . . . . . . . . . . . . 77

6.3 Speedup e eficiência da sessão de teste e da execução das variantes. . . . . . . . . . . 79

7.1 Exemplo de situações no qual ocorre dependência cíclica, causando deadlock na execução determinística. . . . . . . . . . . . . . . . . . . . 85 



\section{Lista de Tabelas}

4.1 Informações registradas para os eventos de sincronização. . . . . . . . . . . . . . . 35

4.2 Exemplo de rastro gerado para o programa representado na figura 4.2. . . . . . . . 36

4.3 Microbenchmarks utilizados durante a implementação e validação dos algoritmos. . 45

4.4 Características dos quatro benchmarks utilizados para avaliar a geração de rastro e execução determinística. São apresentadas as quantidades de: processos, threads, nós transmissores, nós receptores, nós transmissores/receptores (Transm/Recpt), linhas de código (LOC) e complexidade ciclomática (CC) . . . . . . . . . . . . . . 47

4.5 Overhead da execução determinística e tamanho dos rastros para os benchmarks utilizados. . . . . . . . . . . . . . . . . . . . . 48

5.1 Número de elementos requeridos do critério all-sync-edges para os benchmarks utilizados. . . . . . . . . . . . . . . . . . . . 62

5.2 Taxa média de cobertura e de variantes executadas com sucesso considerando a política de novos transmissores apenas para pares ainda não cobertos. . . . . . . . 63

5.3 Taxa média de cobertura e de variantes executadas com sucesso considerando a política de novos transmissores independente de cobertura. . . . . . . . . . . . 64

6.1 Características dos benchmarks selecionados . . . . . . . . . . . 76

6.2 Taxa de cobertura dos elementos requeridos de aresta de sincronização. . . . . . . 76

6.3 Características de hardware e software básico do cluster com treze nós utilizado nos experimentos. . . . . . . . . . . . . . . . . 77

6.4 Tempo médio, speedup e eficiência da sessão de teste para os três benchmarks utilizados. . . . . . . . . . . . . . . . . . . . . . 79

6.5 Tempo médio, speedup e eficiência da execução das variantes para os três benchmarks utilizados. . . . . . . . . . . . . . . . . . . 80 


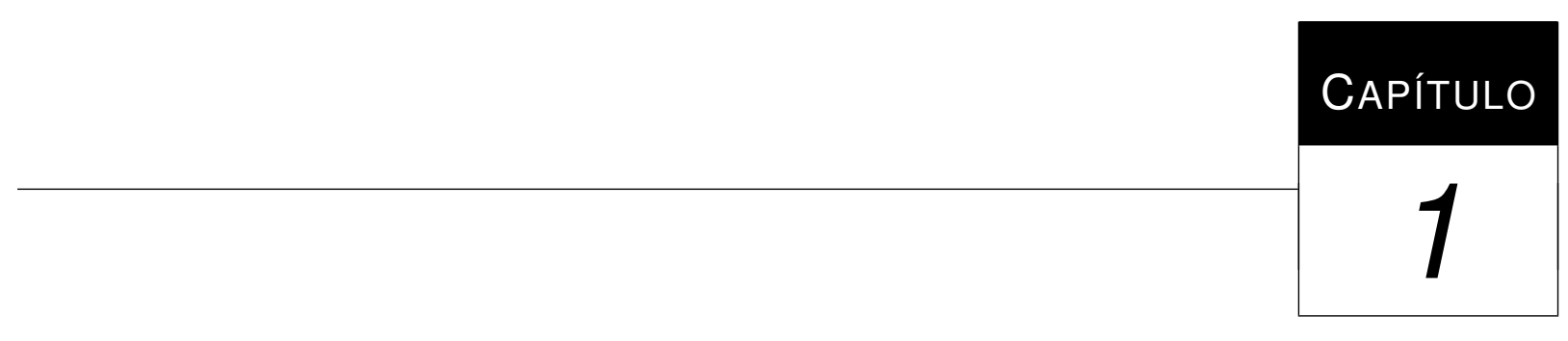

Introdução

A programação concorrente é utilizada em diferentes contextos, como em Sistemas Operacionais, Sistemas Distribuídos e em aplicações de alto desempenho executadas em computadores paralelos (Almasi e Gottlieb, 1994). Estes programas utilizam primitivas de comunicação e/ou sincronização ${ }^{1}$ para que diferentes tarefas executadas concorrentemente colaborem para obter o resultado final da aplicação de forma mais eficiente.

Existem diversas áreas nas quais a programação concorrente está inserida, tais como: motores de busca na web, bioinformática, mineração massiva de dados, simulações em engenharia e previsão do tempo (Grama, 2003; Pacheco, 2011).

Além disto, os computadores de propósito geral multicores tornam-se cada vez mais comuns. A evolução dos processadores altera o processo de desenvolvimento de programas que desejem obter melhorias de desempenho oferecidas pelo mesmo. O uso explícito de primitivas de sincronização é necessário para controlar o acesso a recursos compartilhados entre os processadores.

O uso de primitivas de sincronização traz novos comportamentos e alguns desafios que devem ser considerados durante o desenvolvimento e a validação dos programas concorrentes. Um dos comportamentos apresentados nos programas concorrentes é o não-determinismo, no qual múltiplas execuções de um dado programa com os mesmos dados de entrada podem executar diferentes sequências de sincronização e assim podem produzir diferentes resultados (certos e/ou errados). Este comportamento pode ocultar defeitos como dados compartilhados desprotegidos, deadlocks, starvation, entre outros (Farchi et al., 2003).

Técnicas de execução determinística são amplamente utilizadas para garantir que uma dada sequência de sincronização possa ser re-executada durante a atividade de teste de programas con-

\footnotetext{
${ }^{1}$ No restante do trabalho utilizaremos apenas sincronização para referenciar estes dois termos.
} 
correntes (Carver e Tai, 1991; Alpern et al., 2000; Konuru et al., 2000). Este processo é importante para realizar a validação e a depuração de tais programas.

De maneira geral, as propostas de algoritmos de execução determinística não consideram múltiplos paradigmas de comunicação e sincronização, como passagem de mensagem e memória compartilhada e quando as contemplam não são tão abrangentes quanto a diferentes semânticas e alteram mecanismos do sistema operacional ou ainda da máquina virtual/compilador utilizado.

Este trabalho contribui para a execução determinística considerando diferentes semânticas para programas concorrentes de passagem de mensagem e memória compartilhada. Além disto, a proposta é realizada no nível de linguagem de programação, não sendo necessárias alterações no sistema operacional, na máquina virtual ou compilador.

Diversas propostas para testar aspectos envolvendo as sincronizações de programas concorrentes são apresentadas (Konuru et al., 2000; Edelstein et al., 2001; Stoller, 2002; Lei e Carver, 2006; Musuvathi et al., 2008). De maneira geral, o objetivo destas propostas é explorar diferentes variantes de disputa (race variants) a fim de aumentar a probabilidade de se revelar defeitos difíceis de serem identificados sem o auxílio de ferramentas especializadas.

As principais técnicas para explorar diferentes pares de sincronização são divididas em: teste não-determinístico, teste determinístico e a combinação de ambas as técnicas. No teste nãodeterminístico, um programa é re-executado diversas vezes e espera-se que defeitos sejam expostos. Esta técnica é simples, porém pode ser pouco efetiva. O teste determinístico seleciona pares de sincronização específicos que devem ser executados para aumentar a cobertura de novos pares. Um grande desafio desta técnica é a seleção dos pares a serem testados. A combinação das duas técnicas pode ser utilizada para gerar execuções determinísticas a partir de uma execução não-deterministica, facilitando o processo de seleção de novos pares.

As abordagens encontradas na literatura não contemplam a geração de pares de sincronização para programas concorrentes de passagem de mensagem e memória compartilhada. Este trabalho apresenta como uma de suas contribuições a proposta de um algoritmo que gere pares de sincronização considerando programas concorrentes com ambos paradigmas de sincronização.

As técnicas para explorar diferentes sequências de sincronização geram uma grande quantidade de variantes que devem ser testadas. Programas concorrentes com muitas sincronizações podem necessitar de várias horas para serem validados, o que torna o teste custoso e muitas vezes impraticável.

Reduzir o custo de execução da atividade de teste destes programas é importante para garantir a sua viabilidade. Segundo Delgado (2008) existem duas formas de minimizar o tempo de resposta das ferramentas de teste: reduzir a cobertura dos testes ou paralelizar a sua execução. A primeira abordagem pode comprometer a qualidade da atividade de teste. Com a execução dos testes em paralelo é possível reduzir o tempo do teste sem sacrificar sua cobertura ou qualidade, embora sejam necessários mais recursos computacionais para que a execução paralela seja realizada. 
Algumas propostas de otimização encontradas na literatura em relação à redução do custo da atividade de teste consideram os critérios de cobertura (Taylor et al., 1992; Chung et al., 1996; Yang e Pollock, 2003), a derivação de sincronizações em tempo de execução (Hwang et al., 1995; Lei e Carver, 2006) ou a combinação de técnicas estáticas e dinâmicas (Chen et al., 2009; Souza et al., 2015).

Este trabalho contribui para a redução do custo da atividade de teste de programas concorrentes através da paralelização da execução de pares de sincronização, também apresentada neste trabalho.

\subsection{Objetivos}

O objetivo principal deste trabalho é contribuir para a diminuição do tempo de resposta da atividade de teste estrutural para programas concorrentes, enquanto se aumenta automaticamente a cobertura do código fonte com geração automática de diferentes variantes. Esta redução foi alcançada por meio da paralelização da execução dos algoritmos de geração de pares de sincronização propostos neste trabalho. Como prova de conceito, os algoritmos aqui propostos são aplicados na ValiPar (Souza et al., 2013), uma ferramenta de teste estrutural para programas concorrentes multiparadigma.

\subsection{Organização}

Esta seção descreve a organização desta dissertação. Os Capítulos 2 e 3 tratam da revisão bibliográfica realizada sobre os temas deste trabalho. O Capítulo 2 aborda conceitos de programas concorrentes estabelecendo os limites deste projeto em termos de arquitetura de computadores paralelos e dando uma visão sobre as técnicas e modelos de paralelização de algoritmos.

O Capítulo 3 introduz conceitos básicos de teste de software focando principalmente no teste estrutural de programas concorrentes; além disto, o modelo proposto por Souza et al. (2008, 2013) para teste estrutural de programas concorrentes e a ferramenta ValiPar são apresentados.

Os Capítulos 4, 5 e 6 apresentam a metodologia utilizada para alcançar o objetivo deste projeto e validar os algoritmos propostos.

O Capítulo 4 apresenta novos algoritmos para geração de arquivos de rastro e re-execução determinística de programas concorrentes com passagem de mensagem ponto-a-ponto bloqueante/não bloqueante, passagem de mensagem coletiva e memória compartilhada. Estes algoritmos permitem a execução determinística por meio de primitivas de sincronização da própria linguagem, i.e., estão no nível da aplicação e não requerem privilégios de sistema para serem executados. Eles são baseados na semântica das operações, de acordo com o modelo proposto por Souza et al. (2008). Desta forma são independentes da linguagem de programação que os implementa. Um protótipo dos algoritmos foi desenvolvido na linguagem Java para validar a proposta. 
A execução determinística foi utilizada como base para a proposta de novos algoritmos para explorar diferentes pares de sincronização para programas concorrentes multiparadigma. Os algoritmos utilizam teste de prefixo combinando teste determinístico e não-determinístico guiado por informações extraídas a partir de um modelo estático gerado pela ValiInst (Prado et al., submetido, 2015), o módulo de instrumentação e análise estática da ValiPar. Os algoritmos são discutidos com maiores detalhes no Capítulo 5.

Uma proposta para reduzir o tempo de resposta necessário para validar os programas concorrentes é apresentada no Capítulo 6. Os algoritmos apresentados focam principalmente na distribuição da execução das variantes de disputa geradas pelos algoritmos propostos no Capítulo 5, uma vez que a execução apresenta um grande impacto na atividade de teste estrutural. A validação dos algoritmos paralelos e a análise de desempenho dos mesmos foram realizadas identificando o speedup e a eficiência alcançados em experimentos com benchmarks que representam as sincronizações encontradas em programas concorrentes reais.

O Capítulo 7 apresenta as conclusões obtidas neste projeto. 


\section{Programação Concorrente}

\subsection{Considerações iniciais}

Este capítulo apresenta uma visão geral de programas concorrentes, abordando seus principais conceitos (Seção 2.2). Na Seção 2.3 é apresentada uma classificação de arquiteturas de computadores paralelos e na Seção 2.4 aspectos de softwares concorrentes para máquinas MIMD (Múltiplos fluxos de instruções e múltiplos fluxos de dados) são apresentados.

\subsection{Conceitos básicos e terminologia}

A computação paralela é amplamente utilizada em aplicações que necessitam de alto poder computacional. Seu uso ocorre desde simulações computacionais para aplicações científicas e de engenharia até em aplicações comerciais envolvendo mineração de dados e processamento de transações (Grama, 2003). O paralelismo é o caminho para otimizar computações que demandem, principalmente, longos períodos de tempo e uma grande quantidade de memória (Trobec et al., 2009).

A ideia de computadores com processadores com um único núcleo torna-se cada vez mais ultrapassada e incomum (Gebali, 2011). Desde 2005, ao invés de continuar o desenvolvimento de processadores monolíticos cada vez mais rápidos a maioria dos fabricantes de microprocessadores decidiu caminhar em direção ao paralelismo integrando múltiplos processadores completos em um único circuito integrado (Pacheco, 2011). 
Esta mudança teve consequências significativas no processo de desenvolvimento de software. Diferentemente de melhorar o desempenho dos núcleos monolíticos, o uso de processadores com múltiplos núcleos não melhora implicitamente o desempenho de aplicações seriais, desenvolvidas para executar em um único elemento de processamento. Tais aplicações desconhecem totalmente a existência de múltiplos processadores (Pacheco, 2011), e para que as aplicações se beneficiem dos múltiplos núcleos, é necessário utilizar linguagens de programação ou bibliotecas que forneçam suporte à programação paralela.

Um algoritmo sequencial é essencialmente composto de uma sequência de instruções para resolver um dado problema utilizando uma única unidade de processamento. De forma semelhante, um algoritmo paralelo apresenta a resolução de um dado problema de modo que tarefas independentes possam ser executadas no mesmo instante de tempo (Grama, 2003). Contudo, o desenvolvimento de algoritmos paralelos vai muito além de especificar os passos para atingir a resolução do problema. Além disto, o desenvolvedor deve distribuir as entradas, saídas e dados intermediários associados à resolução do problema, gerenciar o acesso aos dados compartilhados entre múltiplos processadores e sincronizar os processadores em vários estágios da execução do programa paralelo (Grama, 2003).

Os programas concorrentes são uma abstração da programação paralela, podendo ser executados em computadores que possuam processadores com apenas um núcleo, desde que o sistema operacional que esteja executando neste computador dê suporte à multiprogramação (Almasi e Gottlieb, 1994; Grama, 2003). Nestes casos, não existe um paralelismo real entre as atividades, mas um pseudo-paralelismo. Segundo Almasi e Gottlieb (1994), a concorrência ocorre quando, em um determinado instante, duas ou mais tarefas começaram sua execução, mas não terminaram. Dessa forma, duas tarefas são consideradas paralelas quando elas são executadas em núcleos distintos de uma arquitetura multicore no mesmo instante de tempo (Pacheco, 2011). Sendo assim, o paralelismo pode ser classificado como um tipo de concorrência.

No restante deste trabalho, os termos paralelismo e concorrência são tratados como sinônimos dado o contexto do trabalho.

A programação concorrente consiste basicamente no princípio de decompor a resolução de problemas em atividades menores e independentes que possam ser executadas em múltiplos processadores (Pacheco, 2011; Grama, 2003). Estas atividades, quando executadas concorrentemente, tendem a reduzir a ociosidade nos núcleos de processamento diminuindo o tempo de resposta para atingir a resolução do problema (Grama, 2003; Rauber et al., 2010). Em alguns casos, sistemas de alto desempenho também podem melhorar a precisão dos resultados obtidos (Rauber et al., 2010).

Existem duas abordagens amplamente utilizadas para realizar a decomposição de um dado problema em tarefas independentes que possam ser executadas concorrentemente: paralelismo de tarefas e o paralelismo de dados (Pacheco, 2011). No paralelismo de tarefas (ou função) são identificadas tarefas independentes que apliquem diferentes operações no mesmo conjunto de dados. No paralelismo de dados, a decomposição tem por objetivo identificar tarefas independentes que apliquem a mesma operação para conjuntos de dados tipicamente diferentes (Almasi e Gottlieb, 1994). 
O tipo de decomposição a ser utilizado depende muito da aplicação que está sendo paralelizada, sendo necessário que o desenvolvedor tenha um bom conhecimento do domínio da aplicação.

A quantidade de tarefas obtidas e o número de operações realizadas em cada uma destas tarefas determina a granularidade da decomposição. Uma decomposição com uma grande quantidade de pequenas tarefas é chamada de granularidade fina e a decomposição que utiliza uma pequena quantidade de grandes tarefas é chamada de granularidade grossa. A granularidade definirá o nível de concorrência da aplicação, sendo que o nível máximo de concorrência é dado pelo número máximo de tarefas que podem ser executadas em paralelo (Grama, 2003). A escolha da granularidade está altamente ligada ao problema tratado e à plataforma de execução.

As tarefas obtidas por meio da decomposição são executadas por agentes computacionais denominados processos (Grama, 2003). Processos são instâncias de um programa em execução (Pacheco, 2011). Um processo pode conter mais de uma linha de execução que podem compartilhar os mesmos endereços de memória e dispositivos de entrada e saída. Estas linhas de execução são chamadas threads, ou processos leves (Pacheco, 2011).

Os programas concorrentes podem ser classificados em relação ao paradigma de sincronização de duas formas: programas que compartilham memória e programas que realizam passagem de mensagem.

Nos programas concorrentes com memória compartilhada, as threads de um processo compartilham os mesmos endereços de memória, realizando a comunicação de forma implícita por meio de leituras e escritas em variáveis compartilhadas. Porém, são necessários mecanismos de sincronização explícitos, como semáfaros, monitores e variáveis de condição, para garantir a consistência dos dados armazenados em tais variáveis.

Nos programas concorrentes com paradigma de passagem de mensagem, um processo não tem acesso à região de memória de outros processos, sendo necessário o uso de primitivas de transmissão (e.g. send) e de recepção (e.g.receive) que permitam a passagem de mensagem por meio da rede para realizar o compartilhamento dos dados (Pacheco, 2011; Grama, 2003; Dongarra e Lastovetsky, 2009).

Programas híbridos que utilizam ambos os paradigmas de sincronização são cada vez mais comuns para maximizar o paralelismo fornecido pelas arquiteturas de computadores paralelos, a fim de obter melhores resultados.

Para que os programas concorrentes obtenham um melhor desempenho em relação às suas versões sequencias é fundamental que eles sejam executados em uma arquitetura paralela apropriada. A Seção 2.3 descreve uma classificação das principais arquiteturas de computadores paralelos baseada na taxonomia proposta por Flynn (1966). 


\subsection{Arquitetura de computadores paralelos}

Para desenvolver programas concorrentes eficientes é necessário que o programador possua um conhecimento básico sobre a plataforma de hardware que será utilizada no desenvolvimento do programa (Grama, 2003; Pacheco, 2011). A taxonomia proposta por Flynn (1966) é frequentemente utilizada para classificar arquitetura de computadores paralelos (Grama, 2003; Stallings, 2010; Pacheco, 2011; Gebali, 2011).

A taxonomia de Flynn (1966) classifica um sistema de acordo com o número de fluxos de instruções e fluxo de dados que podem ser gerenciados simultaneamente (Pacheco, 2011). O fluxo de instruções é a sequência de operações executadas por uma unidade de processamento (UP). O fluxo de dados é o conjunto de dados manipulados durantes as operações do fluxo de instruções, inclusive, entradas e resultados parciais ou temporários.

Baseado nestes dois conceitos Flynn (1966) organiza os computadores paralelos em quatro categorias:

- SISD (Single Instruction Stream, Single Data Stream - Fluxo único de instruções, fluxo único de dados): possui uma única UP que executa uma única instrução por vez e busca ou armazena um item de dados por vez. A arquitetura clássica de von Neumann é classificada como um sistema SISD (Pacheco, 2011; Flynn, 1966). Nesta categoria não existe paralelismo em nível de instruções ou dados. Um exemplo de uma organização SISD pode ser visualizada na Figura 2.1 (a).

- SIMD (Single Instruction Stream - Multiple Data Stream - Fluxo único de instruções, fluxo múltiplo de dados): esta arquitetura possui múltiplas UP, na qual cada uma delas possui seu próprio caminho conectado à uma memória local. Esta arquitetura permite a execução de uma mesma instrução sobre um conjunto de dados simultaneamente. Processadores vetoriais e matriciais se enquadram nesta categoria (Stallings, 2010; Flynn, 1966). Um exemplo destes tipo de arquitetura são as unidades de processamento gráfico (GPUs - Graphics Processing Units). A Figura 2.1 (b) mostra uma organização do tipo SIMD.

- MISD (Multiple Instruction Stream, Single Data Stream - Fluxo múltiplo de instruções, fluxo único de dados): nesta arquitetura, uma mesma sequência de dados é transmitida sobre um conjunto de UP, na qual cada uma delas executa uma instrução diferente na forma de um pipeline. (Rauber et al., 2010; Flynn, 1966). Arquiteturas do tipo MISD são raras, seu uso tem se limitado à identificação de padrões, criptografia e computação tolerante a falhas (McCormick et al., 2011). Um dos casos mais conhecidos de sua aplicação foi no sistema de controle de vôo fly-by-wire implantado em ônibus espaciais da NASA (National Aeronautics and Space Administration) para identificar processadores com falha no sistema de vôo (Knoll, 1993). 
- MIMD (Multiple Instruction Stream, Multiple Data Stream - Fluxo múltiplo de instruções, fluxo múltiplo de dados): nesta categoria existem múltiplas UP, cada uma delas possui sua própria unidade de controle. Cada UP decodifica sua própria instrução (potencialmente diferente) e acessa o fluxo de dados de maneira compartilhada ou distribuída. Neste tipo de arquitetura as UP geralmente trabalham de forma assíncrona (Rauber et al., 2010; Flynn, 1966). Atualmente, a organização MIMD é amplamente utilizada por ser mais flexível (em termos dos fluxos de instruções e dados) e também por ser uma arquitetura mais próxima aos computadores de propósito geral (Stallings, 2010).

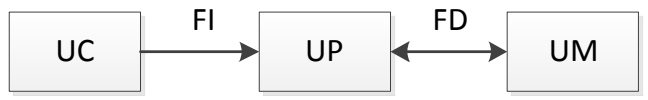

(a) SISD

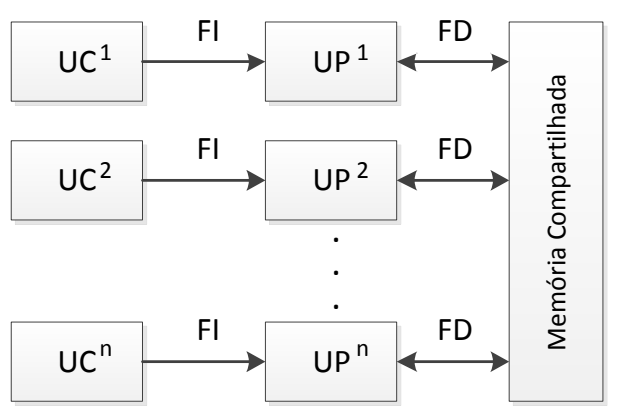

(c) MIMD (com memória compartilhada)

UC - Unidade de Controle

$\mathrm{FI}$ - Fluxo de instrução

UP - Unidade de Processamento

FD - Fluxo de Dados

UM - Unidade de Memória

$\mathrm{ML}$ - Memória Local

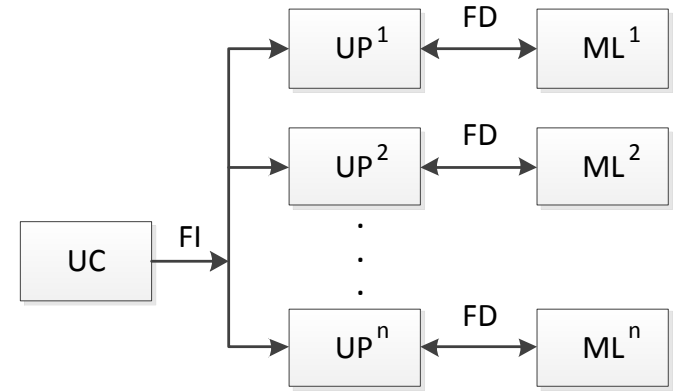

(b) SIMD

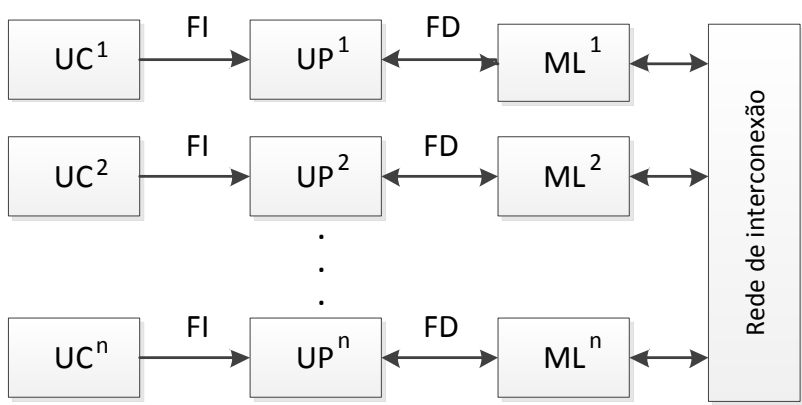

(d) MIMD (com memória distribuída)

Figura 2.1: Organização de computadores paralelos. Adaptado de Stallings (2010).

Existem dois principais tipos de arquiteturas MIMD: memória compartilhada e memória distribuída (Pacheco, 2011).

Nas arquiteturas MIMD com memória compartilhada os processadores acessam programas e dados armazenados em uma memória compartilhada e os processos geralmente se comunicam implicitamente acessando estruturas de dados compartilhadas. Este tipo de arquitetura também é chamada de multiprocessada (multi-core) ou arquitetura MIMD fortemente acoplada (Stallings, 2010; Pacheco, 2011). Uma possível organização de memória compartilhada pode ser vista na Figura 2.1 (c). 
Uma arquitetura MIMD com memória distribuída consiste de elementos de processamento (também chamados de nós) e uma rede de interconexão que conecta os nós e suporta a transferência de dados entre eles. Um nó é uma unidade independente contendo um processador, memória local e, em alguns casos, periféricos (Rauber et al., 2010). Dessa forma, processadores em arquiteturas com memória distribuída geralmente se comunicam explicitamente pelo envio de mensagens ou por meio de instruções que permitam o acesso à memória do outro processador. Exemplos desta arquitetura são os clusters e os MPPs (Massively Parallel Processor) (Pacheco, 2011). Uma possível organização dessas arquiteturas é ilustrada na Figura 2.1 (d).

Os nós das arquiteturas MIMD com memória distribuída podem ter múltiplos processadores que compartilham a memória local (arquiteturas multicores). Para distinguir tais arquiteturas das puramente com memória distribuída, elas podem ser chamadas de arquiteturas híbridas (Pacheco, 2011).

Arquiteturas MIMD com memória distribuída podem ser formadas a partir de uma grande infraestrutura de computadores distribuídos geograficamente por meio de grandes redes de interconexão. Tal infraestrutura é geralmente chamada de grade computacional ( $g$ rid) ou clusters (Pacheco, 2011).

Ao desenvolver programas utilizando recursos de plataformas com memória compartilhada, os programadores contam com o auxílio do sistema operacional e de primitivas de sincronização para distribuir as tarefas entre os processadores. As plataformas com memória distribuída utilizam o envio explícito de mensagens para realizar a sincronização entre os processos (Pacheco, 2011). Um dos problemas dos sistemas de memória compartilhada é a limitação do uso de uma grande quantidade de UP por processador. Adicionar processadores à rede de conexão aumenta significativamente o custo e a chance de conflitos sobre os acessos ao barramento. Por outro lado, a interconexão de sistemas com memória distribuída possui relativamente um baixo custo devido ao fraco acoplamento, mas também é limitado em relação a um grande número de computadores trafegando mensagens na mesma rede (Pacheco, 2011).

Como apresentado anteriormente, não basta que o hardware seja paralelo para obter ganhos de desempenho. O software deve explicitamente fazer uso de primitivas de sincronização para beneficiar-se das arquiteturas paralelas. A Seção 2.4 apresenta uma visão geral sobre software paralelo aplicado a arquiteturas MIMD.

\subsection{Software Paralelo}

Apesar dos hardwares paralelos serem uma realidade, muitos softwares ainda não exploram o potencial das arquiteturas multicores. Com exceções de sistemas operacionais, sistemas de banco de dados e servidores Web, existem poucos softwares comerciais que fazem uso extensivo dos hardwares paralelos (Pacheco, 2011). 
Os softwares que anteriormente dependiam da evolução dos compiladores e do clock dos processadores para obter um melhor desempenho se estagnaram devido à revolução dos processadores multiprocessados. Para melhores desempenhos, desenvolvedores devem aprender a programar aplicações que exploram as arquiteturas de memória distribuída e compartilhada (Pacheco, 2011). Esta seção aborda os conceitos para o desenvolvimento de programas para arquiteturas MIMD (fluxo múltiplo de instruções, fluxo múltiplo de dados), devido ao contexto deste projeto.

Segundo Grama (2003), existem dois passos chaves para a paralelização de um algoritmo. O primeiro deles é dividir a computação em pequenas porções. Esta divisão é chamada de decomposição de tarefas. As tarefas são unidades de computação definidas pelo desenvolvedor em que a computação principal é subdividida por meio da decomposição. Tarefas podem ter tamanhos diferentes, mas são consideradas unidades indivisíveis de computação (Grama, 2003; Rauber et al., 2010).

Ao realizar a decomposição as dependências entre as tarefas devem ser analisadas. Geralmente, para definir tais dependências, utiliza-se um grafo orientado acíclico denominado grafo de dependência de tarefas. Este grafo permite identificar tarefas que podem ser executadas em paralelo. A execução de múltiplas tarefas em paralelo é crucial para reduzir o tempo de reposta das aplicações (Grama, 2003).

O segundo passo chave para a paralelização é atribuir as tarefas a diferentes processos ou threads (Grama, 2003; Rauber et al., 2010). Esta atividade é denominada mapeamento de processos. Um processo ou thread representa um fluxo de controle executado por um processador físico ou core. Um processo ou thread pode executar diferentes tarefas uma após a outra (Rauber et al., 2010). O número de processos ou threads não precisa ser o mesmo número de processadores físicos, mas frequentemente o mesmo número é utilizado (Rauber et al., 2010).

O principal objetivo do mapeamento é realizar a atribuição das tarefas garantindo um bom balanceamento de carga (Rauber et al., 2010). O mapeamento deve buscar maximizar a concorrência, mapeando tarefas independentes em diferentes processos (Grama, 2003). Outro ponto que deve ser considerado no mapeamento é o número de acessos à memória (para memória compartilhada) ou às operações de transmissão de dados (para passagem de mensagem) minimizando a interação entre os processos ou threads (Grama, 2003; Rauber et al., 2010). Mesmo para os algoritmos paralelos mais simples, estes objetivos tendem a ser conflitantes (Grama, 2003).

Existem várias técnicas para realizar a decomposição e o mapeamento. Um modelo de algoritmo paralelo é um padrão adotado pela comunidade para estruturar o algoritmo paralelo, selecionando uma técnica de decomposição e mapeamento e aplicando uma estratégia apropriada para minimizar a sincronização (Grama, 2003). A seguir serão apresentados alguns dos principais modelos de algoritmos paralelos.

- Modelo de paralelismo de dados: neste modelo as tarefas são estaticamente ou semi-estaticamente mapeadas em processos e cada tarefa realiza operações similares em dados diferentes. As tarefas podem ser realizadas em etapas e as operações sobre os dados podem ser distintas. 
Neste modelo, geralmente as etapas de computação são intercaladas com etapas de sincronização para manter a semântica correta dos dados. Este modelo pode ser implementado para ambos os paradigmas (memória compartilhada e passagem de mensagem) (Grama, 2003).

- Modelo de paralelismo de tarefas: para este modelo decompõe-se o algoritmo paralelo na forma de um grafo de dependência de tarefas, o qual é utilizado para realizar o mapeamento das tarefas em processos. Os relacionamentos entre as tarefas são utilizados para promover a localidade e reduzir os custos de interação entre elas. Este modelo é geralmente utilizado para resolver problemas nos quais existam grandes quantidades de dados em relação à computação que deve ser realizada em cada tarefa. Geralmente utiliza-se um mapeamento estático, mas nada impede que um mapeamento dinâmico pode ser utilizado. Este paradigma é mais simples de ser implementado com memória compartilhada (Grama, 2003).

- Modelo Work Pool de tarefas: este modelo caracteriza o mapeamento dinâmico das tarefas para os processos ou threads para balancear a carga. Dessa forma, qualquer tarefa pode ser executada por qualquer processo ou thread. O mapeamento pode ser centralizado ou descentralizado. A carga de trabalho pode ser gerada estaticamente no início da execução ou pode ser gerada dinamicamente. Neste modelo a granularidade das tarefas pode ser ajustada para obter o nível desejado de balanceamento e de acesso ao work pool para adicionar e extrair tarefas (Grama, 2003).

- Modelo mestre-escravo: neste modelo um ou mais processos mestres alocam tarefas para os processos escravos. Este modelo pode ser implementado em memória compartilhada ou passagem de mensagem. A escolha da granularidade das tarefas deve levar em consideração o custo da atribuição das tarefas e das sincronizações. O tempo gasto com as sincronizações deve ser menor que o tempo de execução das tarefas para que o processo mestre não se torne um gargalo (Grama, 2003).

- Modelo Pipeline: neste modelo um fluxo de dados é passado por uma cadeia de processos, cada qual executando uma tarefa diferente sobre os dados resultantes do processo anterior. $\mathrm{O}$ pipeline é uma cadeia de produtores e consumidores, onde cada processo pode ser visto como um consumidor de uma sequência de dados do processo que o precede e como um produtor de dados para o processo que o sucede no pipeline. Os processos podem ser organizados de diferentes formas: linearmente, em estrutura de árvore ou ainda grafos direcionados (Grama, 2003).

- Modelos híbridos: em alguns casos, mais de um modelo pode ser aplicado à resolução do problema em questão. A estas combinações dá-se o nome de modelo de híbrido. Em um modelo híbrido os modelos que o compõe podem ser aplicados hierarquicamente ou sequencialmente em diferentes etapas do algoritmo paralelo (Grama, 2003). Como por exemplo, um servidor de páginas web que recebe requisições dos navegadores pelo modelo cliente- 
servidor e utiliza um modelo work poll de tarefas para distribuir as requisições entre um conjunto de threads.

\subsection{Considerações finais}

Este capítulo abordou de maneira geral os conceitos e definições da área de programação concorrente que são importantes para este projeto. Também foram apresentadas características de arquiteturas paralelas e os paradigmas e modelos de desenvolvimento de software em máquinas MIMD. O projeto insere-se principalmente em arquiteturas paralelas MIMD e em programas multiparadigmas (memória compartilhada e passagem de mensagem).

A criação de programas concorrentes não é uma tarefa trivial e o processo de validação e verificação destes programas inclui uma série de dificuldades inexistentes em programas sequenciais, tais como: não-determinismo, deadlock, starvation, violação de atomicidade, entre outras. O Capítulo 3 apresenta alguns conceitos e técnicas de teste estrutural para testar e validar programas concorrente de modo a aumentar a probabilidade de revelar defeitos relacionados às primitivas de sincronização. 



\section{3}

\section{Teste de Software}

\subsection{Considerações iniciais}

Este capítulo apresenta alguns conceitos básicos sobre teste de software com ênfase em programas concorrentes. A Seção 3.2 apresenta os principais conceitos do teste de software para programas sequenciais. Na Seção 3.3 são apresentados os principais critérios do teste estrutural para programas concorrentes destacando o modelo proposto por (Souza et al., 2008). A Seção 3.4 apresenta alguns trabalhos relacionados ao teste de programas concorrentes. Finalizando, a Seção 3.5 apresenta as considerações finais deste capítulo.

\subsection{Conceitos básicos e terminologia}

O teste de software é uma atividade fundamental para garantir a qualidade de software. Seu objetivo é revelar defeitos por meio da execução de um programa analisando desvios no seu comportamento (Delamaro et al., 2007). Segundo Delamaro et al. (2007) os desvios comportamentais de um programa são classificados da seguinte forma:

- Defeito (fault): uma instrução ou definição de dados incorreta que, se ativada durante a execução do software, pode levar a uma falha; diz-se que o defeito é inerente ao programa e é geralmente inserido por um engano (mistake) do programador ou do analista;

- Erro (error): é um item ou estado inconsistente do programa; considerado como um item dinâmico que geralmente surge após a ativação de um defeito; 
- Falha (failure): é o evento notável no qual o programa viola suas especificações; uma condição indispensável para a ocorrência de uma falha é que pelo menos um defeito seja ativado.

Para avaliar o comportamento de um programa, dados de teste são escolhidos a partir do domínio das entradas do programa. Os dados selecionados são utilizados para executar o programa em teste e a saída obtida é comparada ao resultado esperado. A esta combinação de < dado de teste, resultado esperado $\rangle$ é dado o nome de caso de teste.

Para garantir que um programa está livre de defeitos, ele deveria ser submetido a todas as entradas do domínio. Porém, realizar um teste exaustivo submetendo um sistema a todos os dados do domínio de entrada é em geral impraticável. Por exemplo, um programa que receba duas variáveis do tipo inteiro em um computador com registradores de 32 bits, teria $2 * 2^{32}$ pares de entradas, tornando inviável o teste de todo o conjunto possível de entradas (Huang, 1975).

Para reduzir o conjunto de entradas ao qual o programa deve ser testado, critérios de teste são utilizados. Os critérios de teste auxiliam na seleção dos dados de teste que devem ser utilizados para testar um programa. Os dados de teste indicados pelos critérios devem maximizar a chance de revelar um defeito (Delamaro et al., 2007).

Existem várias técnicas de teste que dividem o domínio de entradas em subdomínios, reduzindo a quantidade de casos de teste necessários para validar o programa, mantendo uma boa probabilidade de revelar defeitos. As principais técnicas são listadas abaixo:

- Técnica funcional: é baseada na especificação do software, com o objetivo de averiguar se o programa satisfaz aos requisitos funcionais e não-funcionais que foram especificados. Exemplos de critérios deste tipo de técnica são (Delamaro et al., 2007):

1. Particionamento em classes de equivalência: identifica condições de entrada relevantes, classificando-as em classes válidas e inválidas, posteriormente, casos de teste que cubram estas classes são selecionados;

2. Análise de valor limite: explora os limites das classes de equivalência, ao invés de selecionar um caso de teste qualquer, um ou mais casos de teste são escolhidos de modo que os valores limites das classes sejam testados;

3. Grafo de causa efeito: explora a combinação dos dados de entrada, identificando causas e efeitos na especificação. As causas correspondem às condições de entrada, ou qualquer coisa que provoque uma resposta do sistema em teste e os efeitos correspondem às saídas, mudanças de estado ou qualquer resposta observável.

- Técnica estrutural: utiliza as estruturas contidas no código fonte de um software para derivar os requisitos de teste de forma significativa e sistemática, cobrindo, por exemplo, comandos, desvios condicionais, definições e uso de variáveis. Seu objetivo é detectar qualquer desvio no comportamento esperado de um determinado software (Cunha et al., 2001). Mais detalhes são apresentados na Seção 3.2.1; 
- Técnica baseada em defeitos: utiliza informações sobre os defeitos mais frequentes ou específicos no processo de desenvolvimento de software para dividir o domínio de entrada. Dois exemplos desta técnica são:

1. Semeadura de erros: uma quantidade conhecida de erros artificiais é introduzida no programa e através de probabilidade a quantidade de erros reais ainda existentes é estimada (DeMillo et al., 1978);

2. Análise de mutantes: um defeito é inserido no código fonte do programa original, e espera-se que ao executar ambos os programas (o original e com o defeito inserido) saídas diferentes sejam geradas. Caso as saídas dos dois programas sejam iguais, pode-se dizer que o conjunto de teste não possui sensibilidade para distinguir o defeito inserido, ou os programas são equivalentes e não existe dado de teste que possa distingui-los. A ideia é mostrar que o programa original não possui determinados tipos de defeito. (DeMillo et al., 1978).

- Técnica baseada em modelo: é uma estratégia que deriva os casos de teste totalmente ou parcialmente do modelo do programa em teste. Para isto, é fundamental que os modelos gerados sejam uma representação fiel do programa. Geralmente, os modelos são representados por meio de máquinas de estados finitos (MEF), e a partir delas são gerados casos de teste. Alguns métodos de geração de casos de teste baseados em MEFs são (Delamaro et al., 2007):

1. Método TT (Transiton tour): a partir do estado inicial, todas as transições são percorridas no mínimo uma vez e retorna-se ao estado inicial. Garante a detecção de defeitos de saída, mas não garante defeitos de transição;

2. Método UIO (Única de entrada e saída): produz uma sequência de identificação de estado. Não garante a cobertura total dos defeitos, pois a sequência de entrada leva a uma única saída na especificação correta, mas isso não é garantido em implementações com defeitos;

3. Método DS (Sequência de distinção): uma sequência de entrada é considerada uma sequencia de distinção (DS) se a sequência de entrada é aplicável a cada estado diferente, mas nem sempre é possível encontrar uma DS para uma MEF;

4. Método W: é um conjunto de sequências que permite distinguir todos os estados e garante detectar os erros estruturais, sempre que a MEF for completa, mínima e fortemente conexa (Chow, 1978).

É importante ressaltar que estas técnicas de teste são complementares e, ao se explorar a melhor forma de uso de cada uma delas, torna-se o teste mais eficaz (Maldonado, 1991).

A atividade de teste é dividida em fases com o objetivo de reduzir e facilitar a execução dos testes, utilizando o princípio de dividir para conquistar. Dessa forma, o teste começa da menor 
unidade executável até atingir o programa como um todo. A seguir são listadas as principais fases da atividade de teste (Delamaro et al., 2007):

- Unidade: concentra os esforços na menor parte executável do programa. Visa a identificação de defeitos de lógica e de implementação;

- Integração: é uma técnica sistemática utilizada para integrar as unidades que compõem o programa. Visa detectar defeitos de integração entre elas;

- Sistema: o teste de sistema é conduzido após a integração do sistema, com o objetivo de identificar defeitos de funcionalidade e características de desempenho.

Considerando o escopo deste trabalho, o teste estrutural será descrito em maiores detalhes a seguir.

\subsubsection{Teste estrutural}

A técnica de teste estrutural considera aspectos da implementação do programa em teste como base para a seleção dos casos de teste. Em geral, o programa em teste é abstraído em um grafo direcionado que represente suas estruturas, tais como desvios condicionais e laços de repetição. Estas estruturas, quando relacionadas a variáveis, dividem o domínio de entradas e estabelecem diferentes porções de códigos que devem ser consideradas durante o teste (Ammann e Offutt, 2008; Lei e Carver, 2006; Delamaro et al., 2007).

Com base neste grafo, os dados de teste são sistematicamente selecionados a fim de maximizar a cobertura de um determinado critério de teste. Quanto mais abrangente for o conjunto de dados de teste maior será a probabilidade de revelar os defeitos existentes no programa (Ammann e Offutt, 2008).

Os critérios definem elementos específicos do programa que pelo menos um caso de teste deve satisfazer ou cobrir. Estes elementos são chamados de elementos requeridos. No teste estrutural estes elementos se referem ao fluxo de controle e ao fluxo de dados do programa em teste. O fluxo de controle são as estruturas do programa, tais como instruções e desvios condicionais e o fluxo de dados são as definições e os usos de variáveis (Maldonado, 1991; Rapps e Weyuker, 1985).

Por exemplo, se o objetivo de um critério é cobrir todos os desvios condicionais do programa (cobertura de arestas), então para cada decisão (e.g. if) existente no programa serão gerados dois elementos requeridos, um para quando a condição for verdadeira (true) e outra para quando for falsa (false).

O teste estrutural define a cobertura como sendo uma métrica pela qual é possível avaliar o quão bom é o conjunto de casos de testes. Dado um conjunto de elementos requeridos para um determinado critério de teste, um conjunto de teste satisfaz este critério somente se para cada elemento requerido existe ao menos um dado de teste que o satisfaça (Ammann e Offutt, 2008). 
A cobertura é importante por duas razões, a primeira delas é que a cobertura total de alguns critérios pode ser muito custosa, e nestes casos pode-se estabelecer um nível de cobertura aceitável a ser atingido. A segunda razão é que podem existir elementos requeridos para os quais não exista um dado de teste capaz de satisfazê-los. Nestes casos, estes elementos devem ser descartados. A este tipo de elemento requerido dá-se o nome de infactível (infeasible) ou não-executável. A detecção de elementos não-executáveis é formalmente indecidível para a maioria dos critérios de cobertura e por isso esta é uma tarefa que cabe ao testador (Goldberg et al., 1994).

Os elementos requeridos de fluxo de controle do programa em teste $P$ são obtidos a partir de seu grafo de direcionado, denominado grafo de fluxo de controle (CFG - Control Flow Graph). Neste grafo, os vértices $(N)$ representam um comando ou um conjunto de comandos sequenciais que podem ser executados como um bloco, sendo que a execução do primeiro comando acarreta na execução de todos os outros comandos deste bloco. As arestas $(E)$ representam o fluxo de controle que interligam os blocos de comandos. Um vértice com múltiplas arestas representa um desvio predicativo (por exemplo, um if) ou um segmento de código com um desvio no último comando do vértice (por exemplo, um laço de repetição) (Taylor et al., 1992).

Um CFG possui apenas um nó de entrada, $s$ onde $s \in N$. O CFG de um programa $P$ é formalmente representado por $C F G(P)=(N, E, s)$ (Delamaro et al., 2007). Uma aresta que liga dois vértices $n$ e $n+1$ é representada pelo par $(n, n+1)$.

Uma extensão do GFC, denominada Grafo def-uso, é utilizada para extraír elementos requeridos relacionados ao fluxo de dados. O grafo de Def-Uso acrescenta informações ao GFC em relação a definição e ao uso de variáveis.

A Figura 3.1(a) representa o grafo de Def-Uso do algoritmo apresentado na Figura 3.1(b). Os números comentados a direita do código na Figura 3.1(b) representa o respectivo nó no grafo (Figura 3.1(a)) no qual a instrução está localizada. O grafo apresentado na Figura 3.1(a) destaca o fluxo de controle e as definições (def) e os usos (uso) de variáveis ao lado dos nós e arestas onde são definidas ou utilizadas.

Existem vários critérios de teste que podem ser definidos em relação ao fluxo de controle e ao fluxo de dados. Três critérios de fluxo de controle bem consolidados são: o teste de caminhos, teste de desvios predicativos (arestas) e teste de comandos (vértices ou nós). No critério todos os caminhos, deve haver casos de teste capazes de exercitar todos os caminhos do programa. Considerando o CFG da Figura 3.1(a), um exemplo dos elementos requeridos de todos os caminhos seria: $\{1,2,7\},\{1,2,3,4,5,7\},\{1,2,3,4,6,2,7\}$ e $\{1,2,3,4,6,2,3,4,5,7\}$. Considerando o mesmo exemplo, seriam necessários no mínimo três casos de teste para cobrir o critério todas as arestas e no mínimo dois casos de teste para o critério todos os nós. Dentre estes três, o teste de caminho (todos-os-caminhos) possui os resultados mais conclusivos, contudo é o mais custoso. Este critério é um dos mais impraticáveis, em vista que, gera uma quantidade exponencial de caminhos a ser testada (Taylor et al., 1992).

Os critérios baseados em fluxo de dados derivam os requisitos de teste baseados nas associações entre definição e uso de variáveis do programa. Tais associações visam exercitar a definição de 


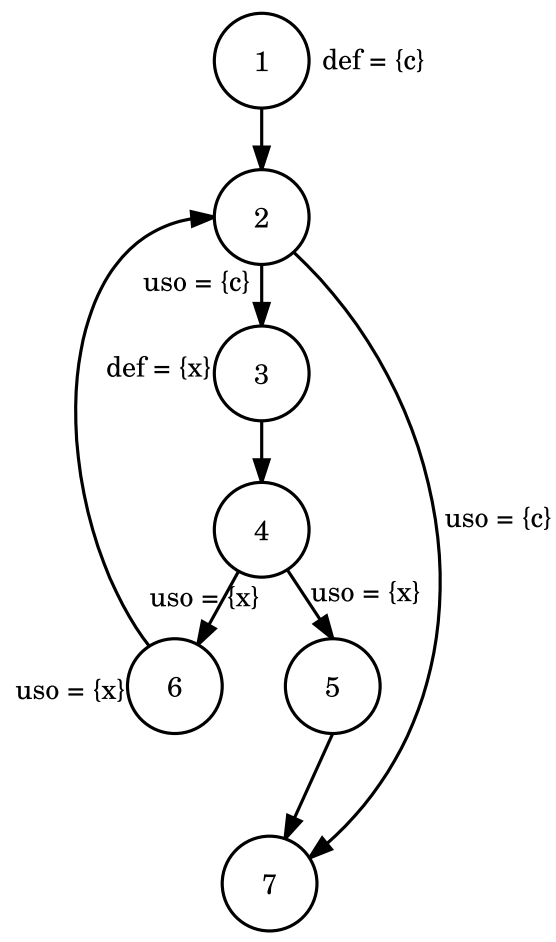

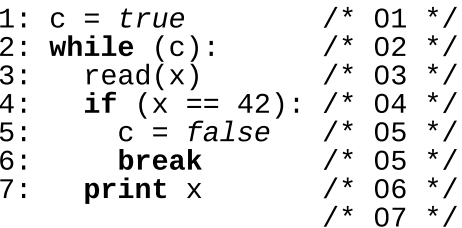

(b)

(a)

Figura 3.1: Exemplo de um grado de Def-Uso fluxo de dados. (a) Grafo Def-Uso, (b) algoritmo exemplo.

variáveis e as referências subsequentes a elas (Weyuker, 1990). A definição de uma variável ocorre quando um novo valor é atribuído a ela. Um uso é uma ocorrência de uma variável que não recebe um novo valor. O uso de variáveis é dividido em uso predicativo (p-uso) e uso computacional (c-uso). P-usos são utilizados em declarações de decisão como while ...do, if . . then ...else ou repeat ... until. Os c-usos são ocorrências de variáveis que não têm seu valor alterado, geralmente, as variáveis do lado direito das atribuições. Os c-usos são associados aos vértices e os p-usos são associados às arestas nos quais ocorrem os usos.

Considerando a Figura 3.1, um exemplo de definição de variável ocorre na linha 3 (vértice 3), p-usos da variável $x$ definida na linha 3 ocorrem nas arestas $(4,6)$ e $(4,5)$ e um c-uso pode ser encontrado na linha 7 (vértice 6) durante a chamada da função $\operatorname{print}(x)$.

Os principais critérios de teste em relação ao fluxo de dados são: todos os usos predicativos (todos-p-usos), todos os usos computacionais (todos-c-usos), todos os usos (todos-usos) e todas as definições e usos (todos-du-caminhos). O critério todos-p-usos gera elementos requeridos para cada aresta onde exista um p-uso associado. O critério todos os usos gera elementos requeridos para cada vértice onde exista um uso computacional. Todos os usos é a combinação dos critérios todos-p-usos e todos-c-usos. O critério todas as definições gera elementos requeridos para cada vértice onde haja uma definição de variável. E o critério todos-du-caminhos é uma associação 
entre os critérios de definição e uso que gera elementos requeridos para todo caminho livre de definição entre os pares de definição e uso de variáveis.

Um caminho livre de definição em relação a uma variável $x$ do vértice $i$ ao vértice $j$ ou à aresta $(j, k)$ é um caminho que não possui nenhuma definição de $x$, exceto possivelmente, no vértice inicial $i$ ou no vértice $k$. Uma associação definição/uso de uma variável $x$ é uma tripla $\langle x, i, j\rangle$ ou $\langle x, i,(j, k)\rangle$, tal que $x$ é definida no vértice $i$ e possui um uso no nó $j$ ou na aresta $(j, k)$. Além disto deve existir um caminho livre de definição com relação a variável $x$ do vértice de definição (i) até o nó $(j)$ ou vértice $((j, k))$ no qual ocorre o uso.

A complexidade destes critérios foi analisada por Weyuker (1990), demonstrando que os quatro primeiros critérios apresentados são de ordem quadrática e o quarto de ordem exponencial.

Uma visão geral de teste estrutural para programas concorrentes é apresentada na próxima seção, destacando o modelo de teste estrutural proposto por Souza et al. (2008) e a ferramenta ValiPar também é apresentada.

\subsection{Teste estrutural de programas concorrentes}

O teste de programas concorrentes tende a ser mais difícil do que o teste para programas sequenciais, pois geralmente, os defeitos encontrados nos programas sequenciais são mais fáceis de serem reproduzidos, sendo necessário apenas fornecer os mesmos dados de teste, enquanto que nos programas concorrentes isto pode não ser o suficiente para a reprodução do defeito. Isto ocorre devido a um comportamento intrínseco deste tipo de programa, o não-determinísmo. Este comportamento é proveniente das primitivas de sincronização, que a cada execução podem formar diferentes pares de sincronização, ainda que os dados de teste não tenham sido alterados (Al-Iadan, 2001).

Além do não-determinismo, os programas concorrentes introduzem novos tipos de defeitos inexistentes nos programas sequenciais, tais como: deadlocks, operações não-atômicas assumidas como atômicas, perda de notificação, entre outros (Farchi et al., 2003).

Um deadlock ocorre quando há uma dependência cíclica no grafo de aquisição de recursos. Um exemplo desta situação é apresentado da Figura 3.2, onde a thread 1 está mantendo o lock L1 e esperando por um segundo (L2); contudo, a thread 2 que mantém o lock L2 e está esperando que L1 seja liberado, formando assim a dependência cíclica. Observa-se que uma execução deste programa de exemplo não leva necessariamente a um deadlock, é necessário que as sincronizações ocorram de tal maneira a formar uma dependência cíclica entre as threads para este defeito ser revelado (Arpaci-Dusseau e Arpaci-Dusseau, 2014).

Além do não-determinismo dificultar a reprodução de defeitos, ele também pode ocultá-los, podendo levar a uma falsa impressão de que o programa está livre de defeitos.

O teste estrutural de programas concorrentes tem como objetivo maximizar as chances de revelar os defeitos ocultados pelo não-determinismo. Para isto, informações do fluxo de sincronização, 


\section{Thread 1: $\quad$ Thread 2: \\ $\operatorname{lock}(\mathrm{L} 1) ; \quad \operatorname{lock}(\mathrm{L} 2)$; \\ lock(L2); $\quad \operatorname{lock}($ L1);}

Figura 3.2: Exemplo de uma situação onde pode ocorrer um deadlock (Arpaci-Dusseau e Arpaci-Dusseau, 2014).

tais como vértices que contenham primitivas de sincronização e arestas que representem os possíveis pares de sincronização são utilizadas para derivar requisitos de teste.

Os critérios de teste propostos por Souza et al. (2008) focam em programas concorrentes com passagem de mensagem, envolvendo primitivas ponto-a-ponto, coletivas, persistentes, bloqueantes e não bloqueantes. Para dar suporte aos critérios, um modelo de teste estrutural extrai informações do programa em teste e o representa em um Parallel Control Flow Graph (PCFG). Exemplo das informações extraídas pelo modelo são: os vértices e arestas intra-processos (fluxo de controle); arestas inter-processos (representando o fluxo de sincronização); e definição e uso de variáveis. As arestas inter-processos consideram arestas de sincronização (s-edges) existentes entre vértices de transmissão (send) e recepção (receive).

Um PCFG de exemplo pode ser visualizado na Figura 3.3, no qual dois processos se comunicam por meio do envio de uma mensagem. As setas sólidas representam o fluxo de controle (intra-processo) e a aresta tracejada representa o fluxo de sincronização (inter-processo).

Alguns dos critérios de teste propostos por Souza et al. (2008) focados na sincronização foram: todos os vértices de transmissão (all-nodes-s), todos os vértices de recepção (all-nodes-r), todas as arestas de sincronização (all-edges-s), todos os usos computacionais de mensagem (s-c-use), todos os usos predicativos de mensagem ( $s$-p-use) e todos usos de mensagem ( $s$-use). Os usos de mensagem estão relacionados a quando uma variável é enviada entre dois processos por passagem de mensagem e esta variável definida no evento de recepção (modifica o valor da variável) tem um uso posterior no processo de destino, que pode ser computacional (s-c-use) ou predicativo (s-p-use).

Considerando a Figura 3.3, uma associação $s$-c-use ocorre na definição da variável $x$ no vértice 0 do processo $p 0 t 0$, o envio de $x$ por meio de um send no vértice 3 do mesmo processo, o recebimento da mensagem no vértice 2 do processo $p 0 t 1$ e seu uso posterior no vértice 4 do mesmo processo. Ressalta-se que deve haver um caminho livre de definição entre a definição da variável e o envio, e entre a definição da variável no vértice de recepção e o uso no processo receptor. Este tipo de critério é utilizado para identificar possíveis defeitos relacionados ao fluxo de dados durante as sincronizações.

Os critérios baseados no fluxo de sincronização geram elementos requeridos utilizando uma abordagem conservadora, na qual cada primitiva de transmissão pode sincronizar com todas as 


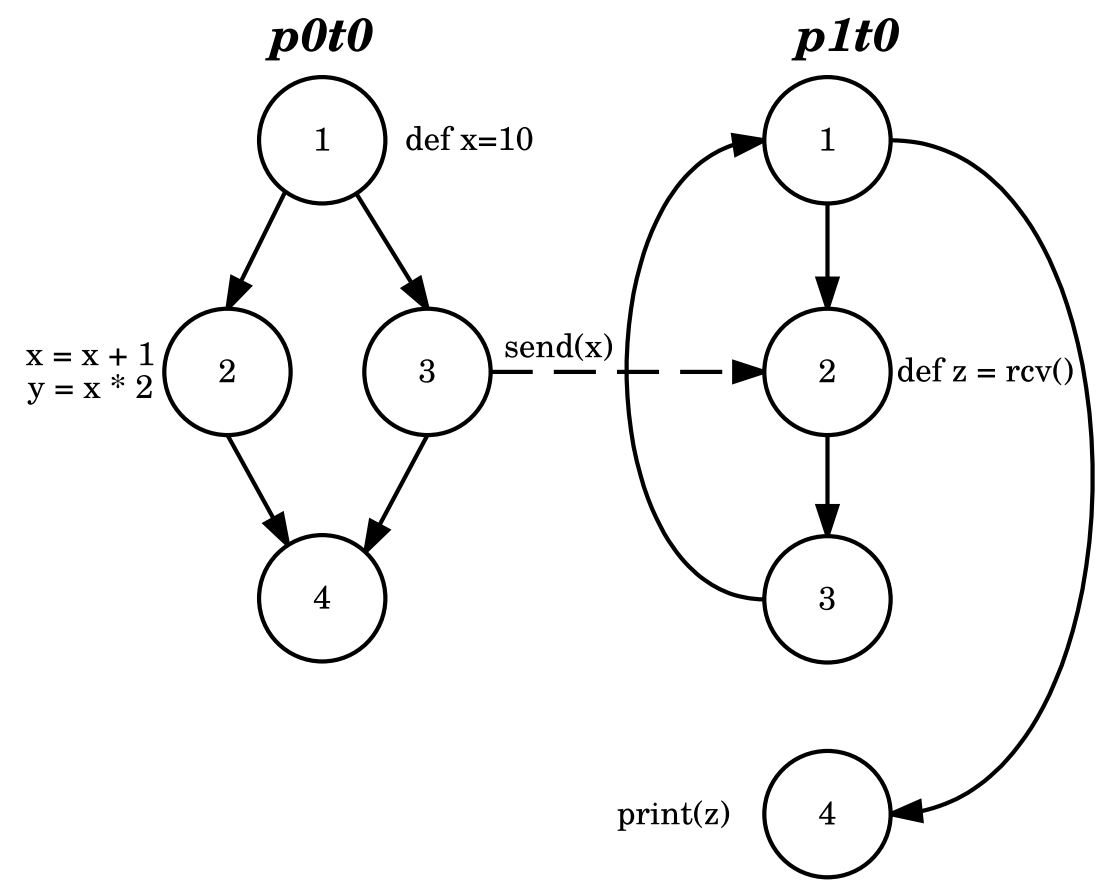

Figura 3.3: Exemplo de um PCFG.

primitivas de recepção de outros processos, obedecendo algumas restrições em relação ao grupo de sincronização ao qual ela pertence (Souza et al., 2008). Por exemplo, uma primitiva de passagem de mensagem ponto-a-ponto não pode estabelecer um par de sincronização com uma primitiva de passagem de mensagem coletiva. Estas primitivas coletivas permitem que um processo sincronize ou envie/receba mensagens de vários processos, ao contrário da comunicação ponto-a-ponto onde apenas dois processos participam desta sincronização.

Neste trabalho, a ferramenta ValiMPI (Hausen, 2005) é apresentada. A arquitetura da ferramenta pode ser visualizada na Figura 3.4.

A ValiMPI é uma ferramenta de teste estrutural para programas concorrentes que implementa o modelo e os critérios propostos para programas concorrentes implementados na linguagem $\mathrm{C}$ com MPI (Souza et al., 2007. cap.9). A ValiMPI é composta de quatro módulos descritos a seguir (Hausen, 2005).

O módulo ValiInst é responsável pela análise estática e instrumentação de programas concorrentes. Por meio da análise, extrai informações do fluxo de controle, do fluxo de dados e do fluxo de sincronização. O módulo também é responsavel pela instrumentação do código fonte inserindo chamadas de funções no código fonte do programa para permitir a geração de arquivos de rastro e execução determinística para programas C/MPI.

A ValiElem é responsável pela geração dos elementos requeridos para os critérios de cobertura citados anteriormente. Esta geração ocorre baseada nas informações extraídas pela análise estática (ValiInst). Neste módulo também é realizada uma redução no número de arestas requeridas iden- 


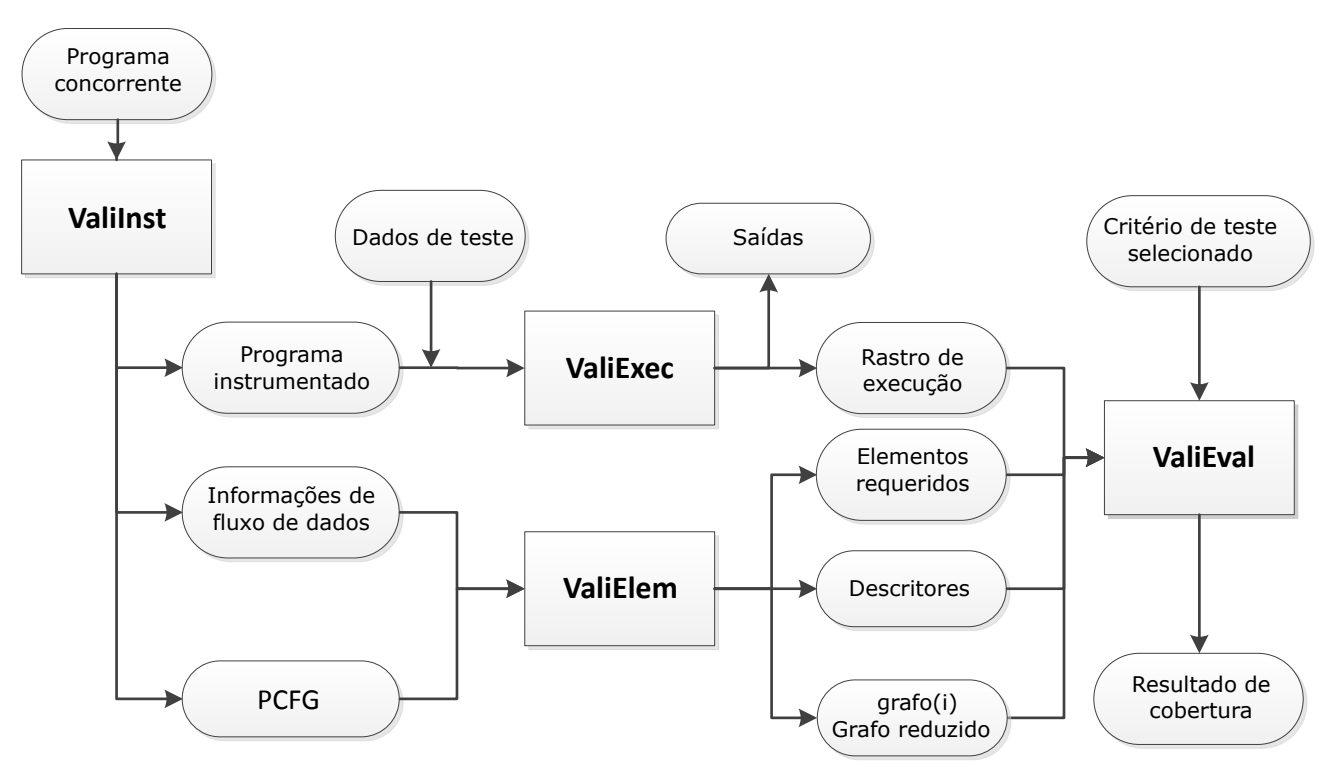

Figura 3.4: Arquitetura da ValiMPI (Souza et al., 2008).

tificadas como não executáveis e estabelece as associações para gerar os elementos requeridos de fluxo de controle, fluxo de dados e fluxo de sincronização, tais como: associações de definição e uso de variáveis e todas as arestas de sincronização.

O módulo ValiExec realiza a execução do programa instrumentado utilizando os casos de teste fornecidos pelo testador. Durante as execuções são armazenadas informações sobre as entradas e saídas do programa, os arquivos de rastro que definem todos os elementos do programa que foram executados (como vértices, arestas, definições e usos) e as informações sobre a sequências de sincronização (pares de sincronização e ordenação dos eventos). A ValiExec também possui um modo de execução controlada que permite que programas em C/MPI possam ser re-executados deterministicamente, auxiliando na depuração de defeitos.

A ValiEval é responsável por avaliar a cobertura obtida nas execuções para cada elemento requerido gerado pelos critérios de teste. Cada elemento requerido é representado por uma máquina de estados finitos (FSM - Finite State Machine) que define os estados e as regras de transições que devem ser satisfeitas no rastro do programa para que o elemento requerido seja coberto. Por exemplo, considerando a Figura 3.3, para cobrir o elemento requerido $\langle x, 0,2\rangle$ de associação de definição e uso da variável $x$, deve haver uma definição de $x$ no vértice 0 , um caminho livre de definição com relação a $x$ do vértice 0 ao vértice 2 e um uso computacional de $x$ no vértice 2 .

Um novo conjunto de critérios para programas de memória compartilhada foi proposto por Sarmanho et al. (2008), estendendo o trabalho de Souza et al. (2008). Neste novo cenário, a comunicação ocorre de forma implícita e desacoplada da sincronização. As sincronizações são explícitas por meio de primitivas de sincronização, como semáforos, e a comunicação ocorre implicitamente por meio da definição de variáveis compartilhadas e o uso por threads distintas do mesmo processo. Sarmanho et al. (2008) considera a linguagem C com PThreads, e uma versão da ValiMPI foi adaptada para este novo paradigma, originando uma nova ferramenta, a ValiPThreads. 
Neste novo modelo, as primitivas são mapeadas como transmissoras (posts) e receptoras (waits) e o fluxo de dados existente entre threads distintas é recuperado dinamicamente por meio do arquivo de rastro. Todas as definições e usos de variáveis globais compartilhadas são extraídas estaticamente do código fonte e as definições dos caminhos livres de definição entre threads distintas são verificadas por meio de uma abordagem dinâmica e post-mortem. Assim uma abordagem híbrida é utilizada, na qual os elementos requeridos são extraídos por métodos estáticos e a avaliação da cobertura dos elementos requeridos inter-threads é realizada por métodos dinâmicos.

A unificação entre estes dois modelos foi proposta por Souza et al. (2013), permitindo que programas concorrentes com ambos os paradigmas de sincronização pudessem ser validados sistematicamente por meio da cobertura de critérios de teste estrutural. Uma segunda contribuição deste trabalho foi a adição da análise de ponteiros (Orso et al., 2001), permitindo a alocação dinâmica de ponteiros, antes não considerada. Este trabalho considerou a linguagem Java como caso de estudo para a aplicação dos critérios (Prado et al., submetido, 2015). A partir deste caso de estudos uma nova ferramenta foi gerada, a ValiPar.

As provas de conceito implementadas neste projeto foram realizadas com base no modelo proposto por Souza et al. (2013) utilizando a ValiPar, uma ferramenta de teste estrutural para programas concorrentes multiparadigmas em Java (Prado et al., submetido, 2015).

A figura 3.5 apresenta a composição atual da ferramenta ValiPar. As principais contribuições deste trabalho encontram-se nos módulos ValiExec, ValiSync e ValiEval. Este trabalho contribuiu com algoritmos de execução determinística e geração de rastro para o módulo ValiExec (Capítulo 4), algoritmos para a geração de novos pares de sincronização foram projetados e implementados no modulo ValiSync (Capítulo 5) e também houveram contribuições em relação a execução paralela destes três módulos (Capítulo 6).

A próxima seção apresenta alguns trabalhos relacionados à área de teste para programas concorrentes.

\subsection{Trabalhos relacionados a teste de programas con- correntes}

Vários outros trabalhos foram propostos na área de teste de programas concorrentes, conforme apresentado na revisão sistemática realizada por Souza et al. (2011). As publicações são distribuídas ao longo de um número discreto de tópicos, tais como: injeção de falhas, verificação formal, análise estática, desenvolvimento orientado a teste, execução controlada, teste de mutação, teste baseado em modelo, teste estrutural, análise simbólica, teste baseado em busca, teste de alcançabilidade, geração de casos de teste, entre outros.

Um dos pontos importantes do teste estrutural de programas concorrentes é avaliar as possíveis sequências de sincronização ( $S Y N$-sequences) de tais programas. O trabalho de Wong et al. (2005) propõe um abordagem para reduzir o custo e os esforços na geração de $S Y N$-sequences. 


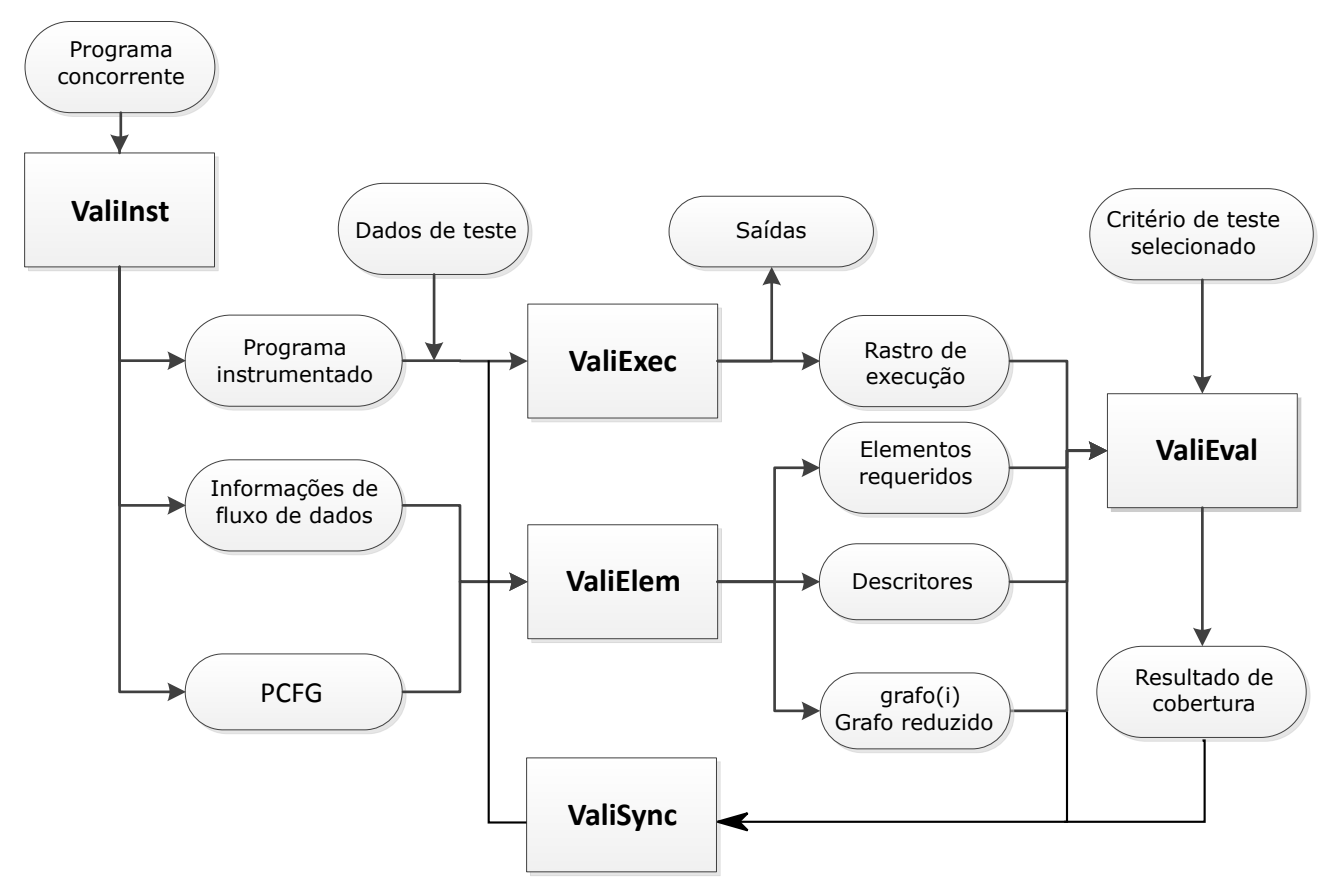

Figura 3.5: Arquitetura da ValiPar.

As sequências de sincronização são geralmente obtidas a partir de um grafo de alcançabilidade (Hwang et al., 1995), extraído durante o tempo de execução do programa. Wong et al. (2005) propõe quatro algoritmos para gerar um conjunto menor de sequências de sincronização, porém que sejam mais eficientes. O termo eficiência neste caso é estabelecido em relação à cobertura de todos os vértices do grafo de alcançabilidade com um conjunto reduzido de sequências de sincronização a serem testadas.

A abordagem envolve a comparação dos algoritmos, sendo dois deles baseados em priorização hot spot e os outros dois baseados em ordenação topológica. Um hot spot é um nó ainda não coberto que possui um grande peso, que se coberto pode aumentar a cobertura de forma eficaz.

Um experimento foi realizado utilizando cinco benchmarks, no qual foram avaliados o total de sequências executadas e a cobertura atingida para os critérios todas-as-arestes e todos-os-nós. Os resultados do experimento mostraram que o método apresentado foi eficiente na cobertura do critério todas-arestas e os algoritmos com base em ordenação topológica obtiveram os melhores resultados, apresentando $100 \%$ de cobertura para o grafo de alcançabilidade e para o critério todasarestas.

Kojima et al. (2009) propõem um modelo de teste estrutural para programas concorrentes com memória compartilhada. O código fonte do programa é classificado em blocos em relação ao uso de recursos compartilhados, no qual um bloco é um conjunto sequencial de código fonte.

A partir dos blocos de código fonte um CMFG (Concurrent Module Flow Graph) é criado. Os blocos que fazem acesso a recursos compartilhados $(E O B)$ são divididos em blocos protegidos, e.g. por um semáforo (MEOB - (MaskableEOB)), e não protegidos (NMEOB - NonMaskableEOB). Os 
blocos concorrentes são ordenados por um vetor de relógios lógicos (happens-before) (Lamport, 1978).

Dois critérios de cobertura são definidos: ACP (All Concurrent Paths) e ACBP (All Concurrent Binomial Path). O primeiro critério visa a cobertura de todas as sincronizações do bloco inicial até o bloco final. O segundo critério verifica somente dois caminhos únicos entre os blocos.

As falhas concorrentes tratadas neste modelo consideram: erros de sincronização de regiões criticas (Wrong Lock or No Lock), operações não atômicas assumidas como atômicas e acesso em dois estágios (variável compartilhada em locks diferentes).

O trabalho porposto por Carver e Lei (2010b) apresenta uma biblioteca para testar programas multithreading. Esta biblioteca consiste de classes para criação de threads e para sincronização de objetos, tais como: semáforos, monitores e passagem de mensagem síncrona e assíncrona.

Esta biblioteca provê suporte para teste e depuração de programas com múltiplas threads e pode ser utiliza em Java e C++ com PThreads para Windows (Win32 API). Também são fornecidos mecanismos para a geração de arquivos de rastros a partir da execução do programa em testes para re-executá-lo posteriormente (record/replay).

Técnicas de teste baseadas em implementação e em especificação também são suportadas na biblioteca, incluindo teste determinístico, teste não-determinístico e também teste de alcançabilidade (Hwang et al., 1995).

Uma das desvantagens da abordagem apresentada por Carver e Lei (2010b) é que o desenvolvedor precisa alterar o código fonte do programa para utilizar as bibliotecas de teste ao invés de utilizar as bibliotecas fornecidas pela própria linguagem.

Christakis e Sagonas (2011) apresentam uma análise estática para detectar defeitos de passagem de mensagem em Erlang, considerando a criação dinâmica de processos e comunicação baseada em passagem de mensagem assíncrona. A proposta analisada é realizada com dialyzer, uma ferramenta que visa um balanceamento sólido e completo utilizando CFGs reduzidos e removendo arestas de sincronização dadas por características de programação Erlang.

O estudo apresentado por Souza et al. (2011) demonstra que a pesquisa na área de teste de programas concorrentes é muito ativa e com publicações relevantes.

\subsection{Considerações finais}

Neste capítulo foram apresentados conceitos e técnicas de teste de software, principalmente de teste estrutural. Também foram apresentados os modelo de teste estrutural para programas concorrentes propostos por Souza et al. (2008), Sarmanho et al. (2008) e Souza et al. (2013). A ferramenta ValiMPI (Hausen, 2005) foi apresentada, bem como uma visão geral dos temas de pesquisa na área de teste de programas concorrentes.

Este capítulo também apresentou alguns dos principais desafios encontrados na atividade de teste estrutural de programas concorrentes, tais como o não-determinismo. O não-determinismo 
dificulta o processo de reprodução e depuração de defeitos e também pode ocultá-los, dando a falsa impressão de que o programa está livre de defeitos. Mecanismos para garantir as mesmas sincronizações são importantes para que seja possível reproduzir e explorar defeitos relacionados à sincronização.

No Capítulo 4 são apresentadas propostas de novos algoritmos para realizar a re-execução determinística para programas concorrentes multiparadigmas, que possibilitam a execução da mesma sequência de sincronização da execução original considerando o mesmo caso de teste. 
CAPÍTULO

4

\section{Geração de Arquivos de Rastro e Execução Determinística para Programas Concorrentes}

\subsection{Considerações iniciais}

Este capítulo aborda o não-determinismo, um dos principais problemas do teste de programas concorrentes, propondo novos algoritmos para a geração de arquivos de rastro e para a execução determinística de tais programas. O texto apresenta uma revisão dos trabalhos relacionados mais relevantes neste contexto, explicando as lacunas existentes nesse domínio. Na sequência são detalhados novos algoritmos para programas com múltiplos paradigmas de sincronização (passagem de mensagem ponto-a-ponto bloqueante e não bloqueante, passagem de mensagens coletivas e memória compartilhada). A validação e a avaliação de desempenho dos algoritmos são feitas com experimentos baseados em nove diferentes benchmarks que exercitam aspectos não triviais de sincronização, encontrados em aplicações concorrentes reais. Os resultados obtidos mostram que os algoritmos apresentam um comportamento robusto e que atingem os objetivos propostos, destacando as sobrecargas geradas durante as suas execuções. Os algoritmos propostos são essenciais para automatizar o teste estrutural de programas concorrentes e formam a base para que novas sincronizações sejam exercitadas automaticamente, aumentando a cobertura do código fonte com foco nas arestas de sincronização. 


\subsection{A re-execução de um programa concorrente}

Uma das questões mais desafiadoras durante o teste de programas concorrentes é lidar com o não-determinismo decorrente do uso de primitivas de sincronização e pelo progresso imprevisível dos processos e threads (Carver e Tai, 1991). Isto significa que múltiplas execuções de um programa com os mesmos dados de teste podem exercitar diferentes pares de sincronização podendo gerar até mesmo saídas diferentes, corretas ou não (Carver e Tai, 1991). Este tipo de comportamento pode ocultar defeitos como dados compartilhados desprotegidos, perda de mensagem ou notificação, deadlocks, starvation, entre outros (Farchi et al., 2003).

As tarefas de depuração e teste de programas concorrentes são extremamente desafiadoras e propensas a erros (Bocchino et al., 2009), pois defeitos revelados em uma execução podem desaparecer em uma próxima, fato que dificulta e encarece a atividade de teste.

A execução determinística garante a execução da mesma sequência de eventos de sincronização para um mesmo caso de teste. Para possibilitar a execução determinística é necessário extrair informações suficientes das sincronizações durante a execução do programa e criar mecanismos que permitam a re-execução da mesma sequência de sincronização da execução original (Carver e Tai, 1991). Os arquivos que armazenam tais informações são chamados de arquivos de rastro (trace files).

Os arquivos de rastro possuem informações sobre a ordem em que os eventos de sincronização foram executados e sobre os pares de sincronização que foram exercitados em uma determinada execução. Tais informações, além de permitirem a re-execução de forma determinística, podem ser utilizadas para avaliar a cobertura de primitivas de sincronização (Souza et al., 2014). Também podem ser utilizadas como base para a geração de novos pares de sincronização, a fim de aumentar a taxa de cobertura (Lei e Carver, 2006) e para determinar a definição e o uso de dados compartilhados (Sarmanho et al., 2008).

A Figura 4.1 ilustra as duas etapas de uma execução determinística: geração de trace e execução determinística. Durante a etapa de geração de arquivos de rastro, o programa em teste é monitorado para obter informações sobre as sincronizações da execução e salvá-las em um arquivo. Quando um programa concorrente é executado deterministicamente, os dados do arquivo de rastro são utilizados para controlar o progresso das primitivas de sincronização de modo que o comportamento da execução seja equivalente ao observado durante a fase de geração de trace.

Este capítulo apresenta novos algoritmos que permitem a geração de arquivos de rastro e a execução determinística considerando programas concorrentes com múltiplos paradigmas de sincronização (passagem de mensagem ponto-a-ponto bloqueante e não bloqueante, passagem de mensagens coletivas e memória compartilhada). As primitivas coletivas consideradas são: umpara-todos, todos-para-um e todos-para-todos. Outro diferencial dos algoritmos propostos é que os mesmos foram desenvolvidos no nível de aplicação, i.e., não requerem alterações nas linguagens de programação ou em bibliotecas de sincronização. 
Os algoritmos propostos estão implementados e validados em um protótipo na linguagem Java. Este protótipo foi submetido a nove benchmarks com diversos padrões de sincronização. Os resultados dos experimentos demostram um comportamento estável de tais algoritmos, sendo que os arquivos de rastro e as execuções determinísticas foram ambos realizados com sucesso.
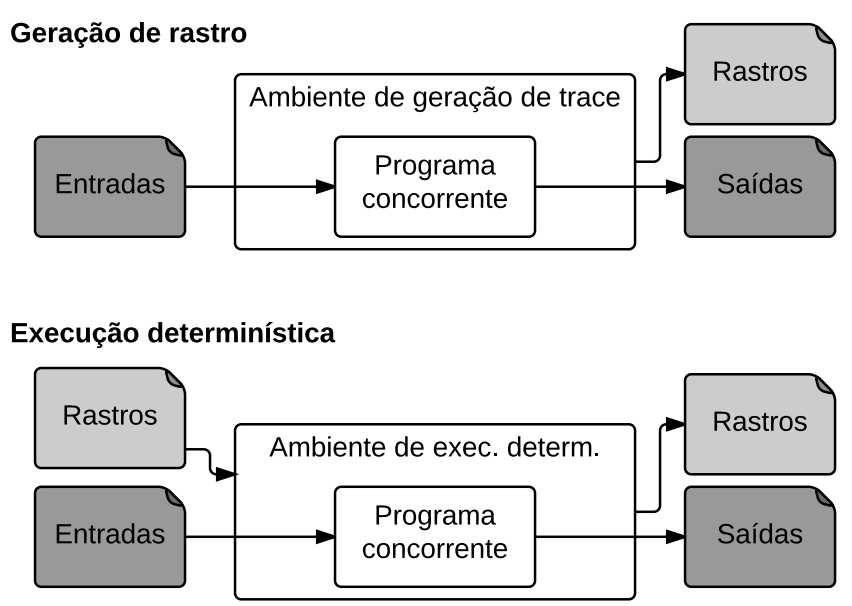

Figura 4.1: As duas fases da execução determinística. Adaptado de Elwakil e Yang (2012).

\subsection{Trabalhos relacionados}

A geração de rastro e a re-execução determinística de programas concorrentes é um tema bem abordado na literatura. A seguir são apresentados alguns dos principais trabalhos encontrados.

Carver e Tai (1991) propuseram uma execução determinística para semáforos e monitores. Sua abordagem utiliza recursos da própria linguagem para manter a mesma ordenação da execução anterior. Durante a geração do rastro é registrada apenas a ordem em que as threads ganham acesso a uma região crítica (usando monitor_enter, semaphore_down). Durante a re-execução determinística, as threads verificam se podem acessar a região crítica com base no rastro da execução original, caso um evento futuro tente acessar a região crítica, a thread aguarda em um semáforo até que o evento corrente notifique as threads que estão aguardando para tentar novamente.

DejaVu (Deterministic Java Replay Utility) (Alpern et al., 2000) é uma ferramenta de reexecução determinística para facilitar a depuração de programas multithread executados na Jalapeño, uma máquina virtual Java (JVM - do Inglês Java Virtual Machine) desenvolvida no IBM T. J. Watson Research Center. Os autores utilizam o conceito de escalonamento lógico de threads, no qual os eventos de sincronização da JVM são globalmente ordenados. Também são estabelecidos intervalos lógicos de escalonamento, minimizando a quantidade de informações necessárias 
para realizar a re-execução determinística. DejaVu Distribuída (Konuru et al., 2000) provê a geração de arquivos de rastro e re-execução determinística para programas que rodam em múltiplas JVMs. Para isto, a ferramenta utiliza uma versão modificada da máquina virtual Java para obter informações sobre as operações TCP e UDP realizadas na API Java de sockets. Estas informações permitem a re-execução de programas de passagem de mensagem. O problema desta abordagem é que a execução determinística é específica para a linguagem Java e depende da maquina virtual modificada Jalapeño.

A ferramenta Microsoft CHESS (Musuvathi et al., 2008) possibilita a re-execução determinística para programas Win32, .NET e Singularity. Ela utiliza um escalonador que observa todas as chamadas realizadas na API do sistema operacional para obter informações sobre a execução e permitir a sua re-execução. As informações de sincronizações são abstraídas utilizando um grafo happens-before proposto por Lamport (1978). Este grafo captura a ordem de execução relativa das threads durante a execução do programa, realizando uma ordenação parcial dos eventos. Porém é necessário um processamento após a execução do programa (post-mortem) para determinar a ordenação dos eventos. A CHESS redireciona todas as chamadas de operações de sincronização para uma biblioteca de wrappers, a qual captura as informações suficientes sobre a semântica das operações e determina a ordem em que os eventos devem acontecer.

Carver e Lei (2010a) criaram uma biblioteca para desenvolvimento, teste e depuração de programas concorrentes em C++ com Pthreads e Java. Esta biblioteca, denominada Modern Multithreading (MM), fornece classes para a criação de threads, permite sincronização de objetos por meio de semáforos e monitores e fornece passagem de mensagem síncrona e assíncrona por meio de channels. Estas classes possuem mecanismos para obter informações sobre as sincronizações e possibilitar a execução determinística de tais programas. Além disto, a biblioteca permite teste não-determinístico por meio da inserção de atrasos entre as sincronizações, teste determinístico no qual é possível forçar a execução de uma sequência de sincronização escolhida pelo testador e teste de alcançabilidade para explorar sincronizações podendo ser realizado em paralelo com múltiplos computadores.

Chaim e de Araujo (2013) propõem uma técnica para reduzir o custo da geração de rastro para fluxo de dados. A proposta utiliza operações binárias e estrutura de dados mais simples para identificar os pares de definição e uso. Os resultados desses autores mostram que os algoritmos apresentam um custo menor para a execução dos testes (em relação ao tempo de execução) e também geram arquivos de rastro com tamanhos reduzidos. Outros trabalhos nessa mesma linha são os desenvolvidos por Lifflander et al. (2014) e Olszewski et al. (2009).

Estes trabalhos relacionados têm como foco principal as primitivas de memória compartilhada, embora alguns abordem a passagem de mensagem síncrona e assíncrona. Outro fator é que as propostas não consideram o uso simultâneo de passagem de mensagens ponto-a-ponto, coletivas e de memória compartilhada no mesmo programa concorrente. Os trabalhos que abordam ambos os paradigmas de sincronização, necessitam que o programador altere o código fonte para utilizar os recursos fornecidos (Carver e Lei, 2010a) ou necessitam de uma JVM específica para funci- 
onar (Konuru et al., 2000). De fato, há várias propostas que são específicas a uma linguagem, por depender da API do sistema operacional ou modificar a JVM. Os algoritmos propostos neste capítulo para a geração de arquivo de rastro e execução determinística diferenciam-se dos demais, por serem mais abrangentes, oferecendo soluções no nível da aplicação e para várias primitivas de sincronização em ambos os paradigmas.

\subsection{Algoritmos para geração de rastro e execução deter- minística}

Os algoritmos desenvolvidos atuam no nível de usuário utilizando recursos de sincronização fornecidos pela própria linguagem de programação. Para isto, é realizada uma análise estática do programa concorrente para identificar suas primitivas de sincronização e em seguida o programa é instrumentado com chamadas de métodos invocados antes e depois de cada primitiva. A instrumentação transforma o programa concorrente em um programa levemente modificado equivalente ao original, exceto pela coleta de informações e mecanismos para controlar a execução do programa. A análise estática e a instrumentação são feitas pelo módulo ValiInst da ValiPar (Prado et al., submetido, 2015) e suas particularidades não serão detalhadas neste texto.

O Algoritmo 1 representa a modificação realizada para cada primitiva do programa instrumentado. O algoritmo pode ser executado no modo livre, no qual a execução do programa concorrente ocorre de forma não-determinística e também no modo determinístico. Para ambos os modos de execução são gerados arquivos de rastro identificando a sequência de sincronização e os pares de sincronização que ocorreram durante a execução do programa concorrente.

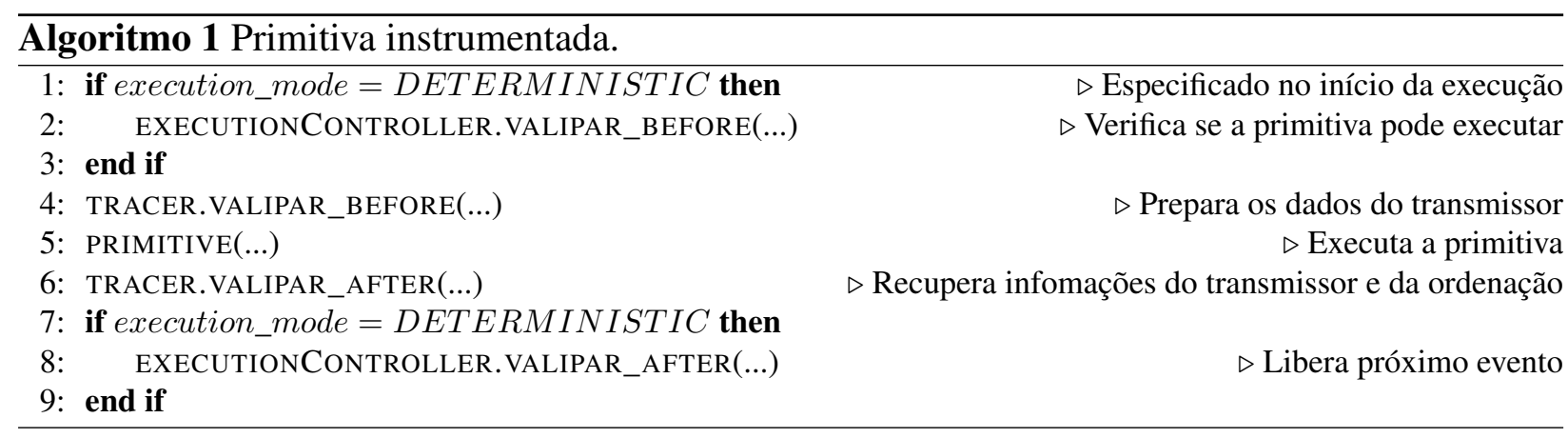

As duas modalidades de execução são divididas em antes (before) e depois (after) da execução da primitiva. De maneira geral, durante a geração do rastro o método tracer.valipar_before() coleta informações do transmissor e o método tracer.valipar_after() recupera a informação do par de sincronização e a ordem global em que o evento foi executado.

Na execução determinística, o método executionController.valipar_before() verifica se a primitiva pode ser executada, baseando-se nos arquivos de rastro da execução original. Caso não seja o momento correto para a sua execução a primitiva bloqueará até receber uma notificação de que ou- 
tra primitiva foi executada e que então ela pode verificar novamente se pode prosseguir. O método executionController.valipar_after() notifica os eventos que estão aguardando para executar.

Os algoritmos desenvolvidos baseiam-se no modelo de análise estática para programas concorrentes (Souza et al., 2014) e (Souza et al., 2013). O modelo organiza as primitivas de acordo com sua semântica permitindo que os algoritmos possam ser aplicados independentemente da linguagem utilizada, como por exemplo para Java ou C com MPI/PThreads.

O modelo extrai informações sobre o fluxo de controle, de dados e de sincronização e as representa em um grafo de fluxo de controle paralelo (PCFG - Parallel Control Flow Graph). Cada nó deste grafo corresponde a um conjunto de instruções executadas sequencialmente (sem um desvio condicional) ou a uma primitiva de sincronização (Souza et al., 2014) (Souza et al., 2013).

As primitivas de sincronização são classificadas em função do tipo de evento (transmissor, receptor ou transmissor-receptor) e da semântica da operação (bloqueante e não-bloqueante). Assim, uma primitiva pode ser classificada como: transmissor bloqueante (BS - Blocking Send), receptor bloqueante (BR - Blocking Receive), transmissor não-bloqueante (NS - Non-Blocking Send), receptor não-bloqueante (NR - Non-Blocking Receive), transmissor-receptor bloqueante (BSR - Blocking Send-Receive) e transmissor-receptor não-bloqueante (NSR - Non-Blocking Send-Receive).

Souza et al. em (Souza et al., 2014) também definem clusters de sincronização para evitar que pares de sincronização sejam estabelecidos entre primitivas com semânticas diferentes durante o processamento das informações coletadas estaticamente. Por exemplo, um receptor de passagem de mensagem coletiva não pode receber uma mensagem de um transmissor de passagem de mensagem ponto-a-ponto ou sincronizar com um semáforo. Semáforos distintos também não interagem e, portanto, utilizam clusters distintos.

As primitivas de sincronização foram agrupadas em: passagem de mensagem, semáforos (sendo cada semáforo um cluster distinto) e passagem de mensagem coletiva. As primitivas de comunicação coletiva ainda podem ser subdivididas em: um-para-todos (one-to-all), todos-paraum (all-to-one) e todos-para-todos (all-to-all). Tais agrupamentos são utilizados para identificar os pares de sincronização durante a geração do rastro e para a tomada de decisões durante a execução determinística.

As principais características dos algoritmos de geração de arquivo de rastro e execução determinística são descritos nas Sessões 4.4.1 e 4.4.2.

\subsubsection{Geração de arquivos de rastro}

A geração de arquivo de rastro considera que cada thread do programa concorrente mantém uma lista dos eventos de sincronização que ocorrem nela durante uma execução. Cada evento inserido nesta fila possui uma identificação única, de modo que evento de sincronização do nó $n$, da thread $t$ e do processo $p$ é unicamente identificado pela tupla $\left\langle n^{p, t}, e\right\rangle$, onde $e$ é o número do evento sequencialmente enumerado por thread. O número do evento é importante para distinguir 
um nó que é executado dentro de um laço de repetição, i.e. um novo evento marca uma nova execução de um nó, mesmo que repetidamente.

Cada evento na fila registra o tipo do evento (Transmissor, Receptor ou Transmissor-Receptor) e o cluster ao qual o evento pertence. Os receptores, além disso, também possuem informações sobre os eventos transmissores que sincronizaram com este receptor e também recebem um relógio lógico global (um timestamp representado por $t s \_g l o b a l$ ) para a aplicação concorrente. Cada evento possui um estado, que representa se o evento estabeleceu de fato um par de sincronização no momento do retorno da primitiva. A Tabela 4.1 representa os campos salvos para os eventos nos arquivos de rastro.

Tabela 4.1: Informações registradas para os eventos de sincronização.

\begin{tabular}{|c|c|c|c|c|c|}
\hline $\begin{array}{l}\text { Identificador } \\
\text { do evento }\end{array}$ & $\begin{array}{l}\text { Cluster de } \\
\text { sincronização }\end{array}$ & $\begin{array}{l}\text { Semântica da } \\
\text { operação }\end{array}$ & $\begin{array}{l}\text { Identificador } \\
\text { do transmis- } \\
\text { sor }\end{array}$ & $\begin{array}{l}\text { Relógio } \\
\text { lógico }\end{array}$ & $\begin{array}{l}\text { Estado } \\
\text { evento }\end{array}$ \\
\hline $\begin{array}{l}\text { Identificador } \\
\text { único do } \\
\text { evento. }\end{array}$ & $\begin{array}{l}\text { Identifica o } \\
\text { cluster do } \\
\text { evento de } \\
\text { sincronização. }\end{array}$ & $\begin{array}{l}\text { Determina a } \\
\text { semântica das } \\
\text { operações de } \\
\text { sincronização } \\
(\mathrm{BS}, \quad \mathrm{BR}, \\
\mathrm{BSR}, \ldots) .\end{array}$ & $\begin{array}{l}\text { Caso evento } \\
\text { receptor, iden- } \\
\text { tifica evento } \\
\text { transmissor } \\
\text { que estabele- } \\
\text { ceu um par de } \\
\text { sincronização. }\end{array}$ & $\begin{array}{l}\text { Determina a } \\
\text { ordem em que } \\
\text { o receptor foi } \\
\text { executado. }\end{array}$ & $\begin{array}{l}\text { Determina se } \\
\text { a operação } \\
\text { foi concluída } \\
\text { no momento } \\
\text { do retorno da } \\
\text { primitiva. }\end{array}$ \\
\hline
\end{tabular}

Para estabelecer os pares de sincronização considera-se o critério FIFO (First-In-First-Out), assumindo que as mensagens são recebidas na ordem em que são enviadas e que as filas dos semáforos acordam as threads na ordem em que as threads solicitaram acesso à região crítica.

O $t s \_g l o b a l$ atribuído aos eventos receptores representa a ordem cronológica em que os eventos foram executados. Ele é atribuído por meio de um processo externo denominado Processo de Controle (PC - ou, do Inglês, Control Process CP). Este PC é iniciado junto com o programa instrumentado e gerencia a atribuição de valores para o $t s \_g l o b a l$. As atribuições ocorrem por meio de passagem de mensagem. O ts_global determina a ordem em que os receptores serão executados durante a execução determinística. Ele começa em zero e é incrementado a cada solicitação feita ao PC.

No Algoritmo 2 são representados os passos necessários para geração do arquivo de rastro considerando primitivas de passagem de mensagem bloqueante. Antes de uma primitiva de passagem de mensagem bloqueante ser executada a função valipar_before será invocada tanto para o transmissor quanto para o receptor. Se o evento for um transmissor, a identificação do evento será adicionada na própria mensagem a ser enviada; caso seja o receptor nenhum passo adicional será realizado e a primitiva será executada.

Após a execução das primitivas de transmissão e de recebimento, a função valipar_after será invocada. Para o evento transmissor a função irá apenas salvar o evento na fila da thread que será 
armazenada no arquivo de rastro. Caso o evento seja um receptor bloqueante, a thread receptora ganha o semáforo tsPairSem para garantir que ela irá recuperar também o $t s \_g l o b a l$ sem interferência de outra thread receptora. Ao ganhar o semáforo, a thread receptora envia uma mensagem ao PC, solicitando um $t s \_g l o b a l$. Caso seja o primeiro evento receptor a executar, ela receberá uma mensagem com o valor zero. A thread receptora retira a informação do transmissor da mensagem e libera a região crítica. Neste momento o evento receptor é adicionado à fila da thread.

A Figura 4.2 apresenta um diagrama espaço-tempo para um programa com passagem de mensagem bloqueante. Nesta figura há três processos ( $p 0 t 0, p 1 t 0$ e $p 2 t 0)$, dois eventos transmissores (s0 e s1) que competem pelos eventos receptores ( $\mathrm{r} 0$ e r1) do processo $p 1 t 0$. As arestas de sincronização $\alpha$ e $\beta$ (linhas tracejadas) representam os pares de sincronização formados em uma dada execução: $s 0 \rightarrow r 0$ e $s 1 \rightarrow r 1$. As letras (a) e (b) representam as chamadas ao método valipar_before dos transmissores, onde a identificação do transmissor é adicionada na mensagem e as letras (c) e (d) representam as chamadas ao método valipar_after dos receptores, onde são atribuídos o $t s \_g l o b a l$ e o par de sincronização.

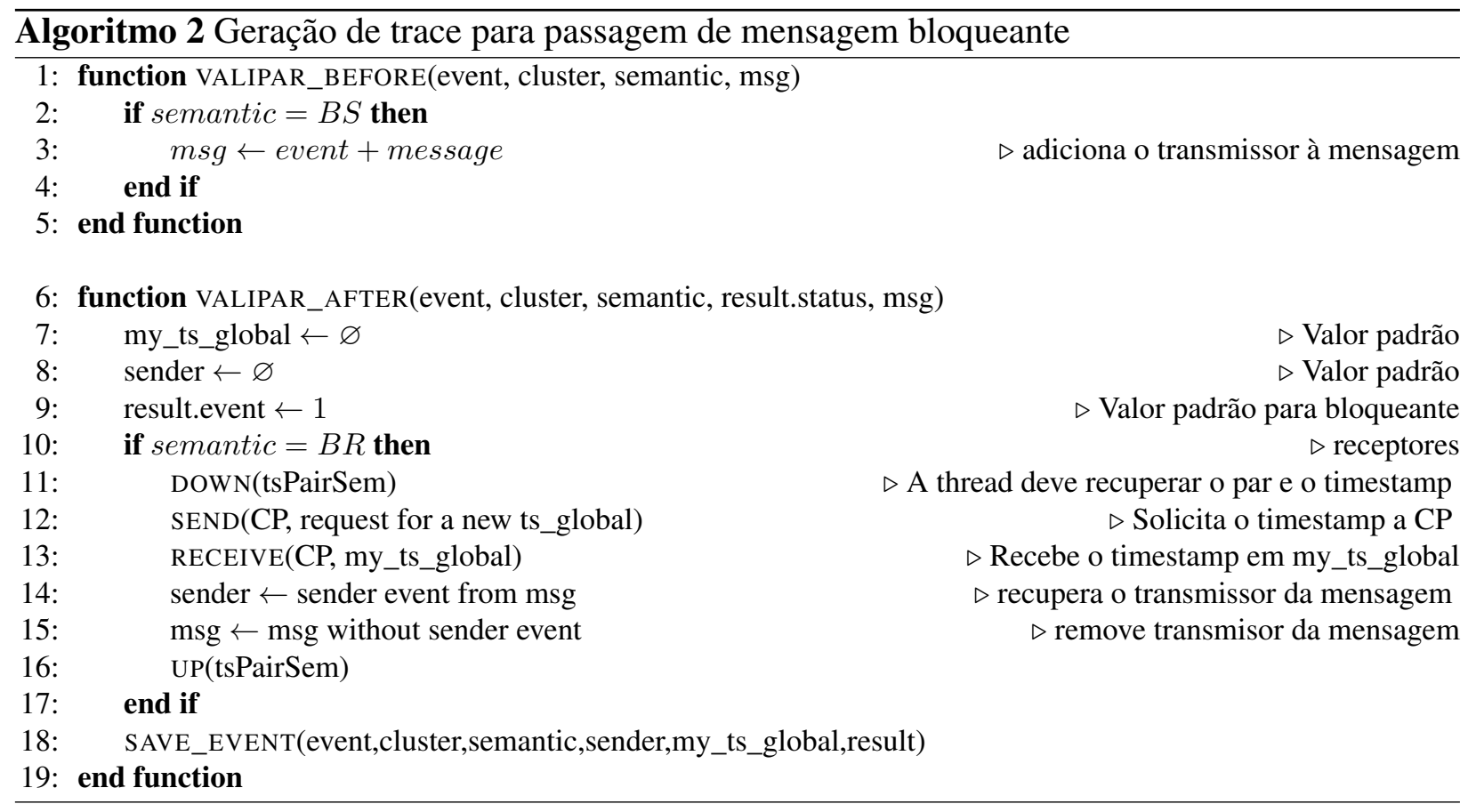

\begin{tabular}{|c|}
\hline p0t0 \\
\hline$\left\langle 0^{0,0}, 0\right\rangle$, PASSAGEM-MENSAGEM, BS, $\varnothing, \varnothing, 1$ \\
\hline p1t0 \\
\hline$\left\langle 0^{1,0}, 0\right\rangle$, PASSAGEM-MENSAGEM, BR, $\left\langle 0^{0,0}, 0\right\rangle, 0,1$ \\
$\left\langle 1^{1,0}, 1\right\rangle$, PASSAGEM-MENSAGEM, BR, $\left\langle 0^{2,0}, 0\right\rangle, 0,1$ \\
\hline p2t0 \\
\hline$\left\langle 0^{2,0}, 0\right\rangle$, PASSAGEM-MENSAGEM, BS, $\varnothing, \varnothing, 1$ \\
\hline
\end{tabular}

Tabela 4.2: Exemplo de rastro gerado para o programa representado na figura 4.2. 


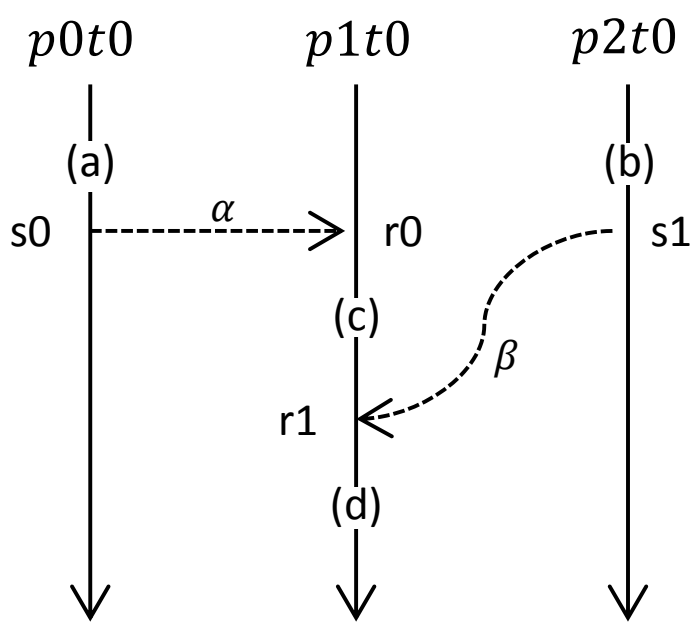

Figura 4.2: Diagrama espaço-tempo de um programa de passagem de mensagem bloqueante.

O Algoritmo 3 representa a geração de rastro para memória compartilhada com semáforos. A diferença para o algoritmo de passagem de mensagem bloqueante é que ao invés do transmissor inserir sua identificação na mensagem ela será adicionada à uma fila protegida por um semáforo (queиeSem). O mesmo ocorre com o receptor ao obter a informação do transmissor, ao invés de retirá-la da mensagem a identificação é recuperada da fila.

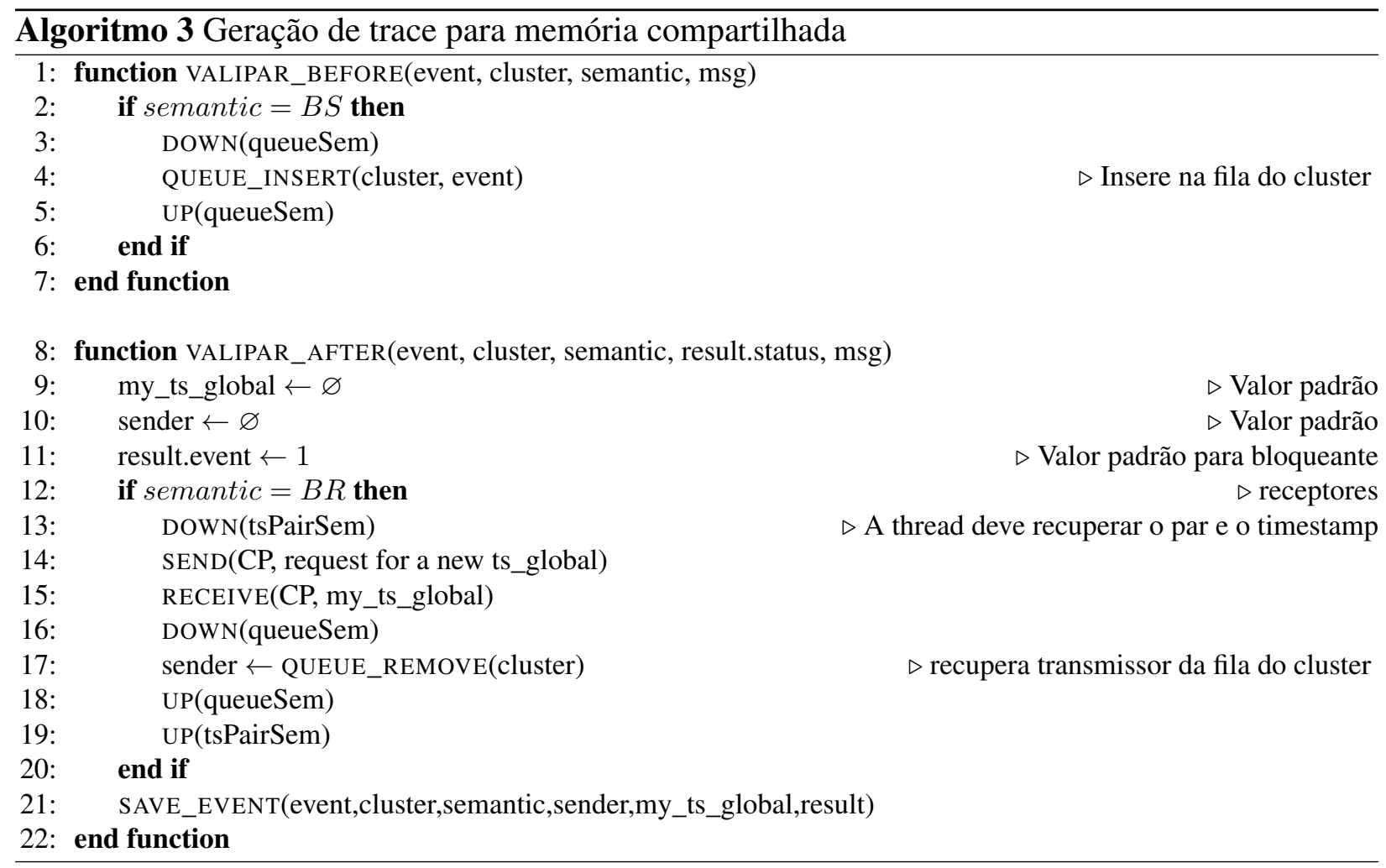

Em geral, as primitivas passagem de mensagem não bloqueantes podem funcionar de duas maneiras: (a) elas são executadas em segundo plano e retornam um identificador para que seja 
possível consultar o estado da operação (caso do MPI (Pacheco, 1996)); ou (b) duram apenas o tempo da chamada e retornam a quantidade de bytes enviados/recebidos, caso a mensagem não tenha sido totalmente transmitida ou recebida é necessário chamar a primitiva novamente (caso dos SocketChannels em Java e da primitiva pvm_nrecv() do PVM). O algoritmo proposto para passagem de mensagem não-bloqueante contempla os dois tipos de eventos não bloqueantes (Algoritmo 4). Para o primeiro caso (a) além do cluster de passagem de mensagem são introduzidos mais dois novos clusters: wait e test. Tais clusters representam as primitivas que verificam o estado de uma primitiva não bloqueante com base no identificador retornado. A primitiva wait tem um comportamento bloqueante, enquanto a primitiva test tem um comportamento não bloqueante.

O ts_global e o par de sincronização são atribuídos apenas para eventos receptores (inclusive test e wait de primitivas de recebimento) que efetivamente receberam uma mensagem (Algoritmo $\left.4.14^{1}\right)$.

Assim como no algoritmo de passagem de mensagem bloqueante, a geração de rastro para primitivas não-bloqueantes utiliza a própria mensagem para inserir a identificação do transmissor. A diferença ocorre durante a função valipar_after, onde é necessário utilizar o identificador retornado pela primitiva não-bloqueante é inserido em uma tabela hash, onde o identificador é a chave e o valor é uma tupla com a identificação e a semântica da primitiva original (Algoritmo 4.23). Quando uma primitiva test ou wait for executada estas informações serão recuperadas da hash para que sejam salvas no rastro (Algoritmo 4.10-13). Para este caso, o estado do arquivo de rastro é uma tupla do identificador do evento de origem e do estado da primitiva.

As sincronizações feitas com primitivas coletivas foram organizadas nos seguintes clusters: one-to-all, all-to-one e all-to-all. Uma fila é utilizada para registrar os pares de sincronização que participam dessas sincronizações. Essa fila precisa ser acessível a todos os processos/threads concorrentes que participam de alguma sincronização e, dessa forma, a mesma foi alocada no PC. A troca de mensagens permite a inserção e a recuperação de dados na fila. O Algoritmo 5 mostra o método valipar_before para as primitivas coletivas onde ocorre a inserção do transmissor na fila do cluster. Um comunicador (communicator) foi criado para para identificar subgrupos dentro de um mesmo cluster. Esse subgrupo separa, por exemplo, duas barreiras ou grupos distintos de broadcast que, apesar de pertencem ao mesmo cluster, não interagem. A criação desses subgrupos é dinâmica e não estática, por meio do código fonte, porque a necessidade dos mesmos é determinada em tempo de execução, em função do fluxo de execução das threads.

O PC mantém uma fila para cada (cluster) de primitivas coletivas. Ao receber uma requisição de inserção, uma estrutura de dados é adicionada à fila do cluster contendo a identificação do evento transmissor e o comunicador (communicator).

O Algoritmo 6 exibe a função valipar_after de geração de rastro para primitivas coletivas allto-all. Neste tipo de operação cada evento participante sincroniza com todos os outros eventos. Portanto não é necessário que os eventos sejam re-executados em uma ordem específica durante

\footnotetext{
${ }^{1}$ Algoritmo $x . y$ indica a linha $y$ do algoritmo $x$.
} 

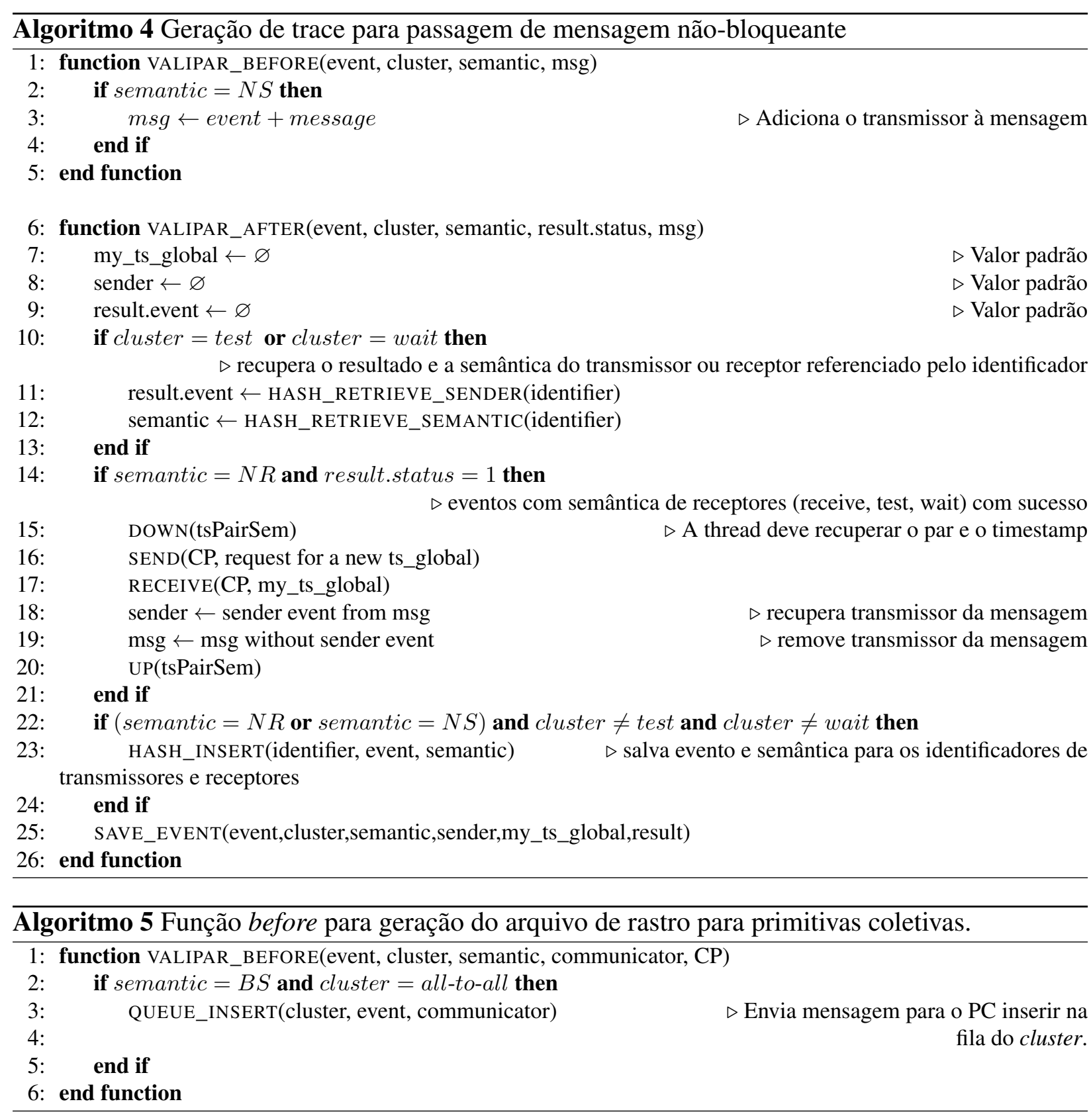

a execução determinística e dessa forma tais eventos não necessitam receber um $t s \_g l o b a l$. Após a execução de uma primitiva coletiva cada evento envia uma mensagem para o PC solicitando os eventos que fizeram parte desta sincronização (Algoritmo 6.6). Como resposta, o PC retorna uma mensagem contendo a lista de eventos participantes desta sincronização.

O Algoritmo 7 exibe a busca realizada pelo PC para resgatar os eventos que fizeram parte de uma sincronização coletiva. Este algoritmo retorna todos os eventos que pertençam ao mesmo cluster, tenham o mesmo comunicador (communicator) e que sejam diferentes e ainda não tenham sido selecionados ao evento que está buscando pelos transmissores.

O Algoritmo 8 apresenta a função valipar_after da geração de rastro para primitivas coletivas todos-para-um. Nestas primitivas exitem $n$ transmissores para apenas um receptor e um exemplo das mesmas é a função MPI_Gather do MPI. Após a execução da primitiva, os eventos transmis- 

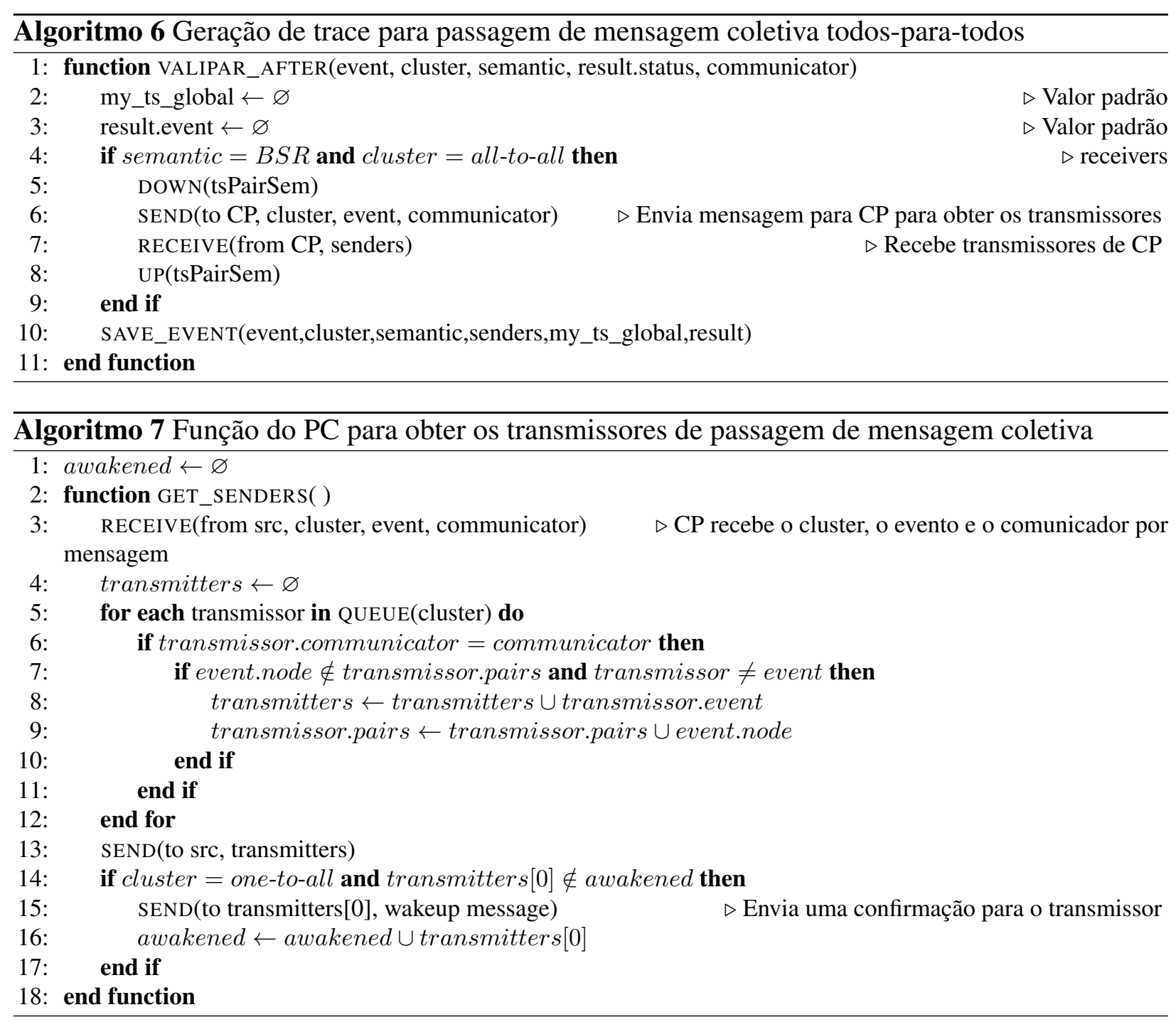

sores aguardam uma mensagem do receptor para poderem prosseguir. $\mathrm{O}$ evento receptor solicita $\mathrm{o}$ $t s \_g l o b a l$ e a lista de transmissores para o PC. Ao recebê-los, o evento receptor envia uma mensagem para cada um dos transmissores liberando-os. Após esta sincronização os eventos são salvos no rastro.

A função valipar_after para primitivas coletivas um-para-todos é exibida no Algoritmo 9. Este tipo de primitiva possui apenas um transmissor e $n$ receptores. Exemplos deste tipo de primitiva seriam o MPI_Bcast em MPI e o MulticastSocket em Java. Após a execução da primitiva de envio, o transmissor irá aguardar uma confirmação do PC que ao menos um receptor recebeu a mensagem (Algoritmo 9.6). Cada receptor ao receber a mensagem solicita o $t s \_g l o b a l$ e o transmissor ao PC. Após retornar o transmissor para o primeiro evento que solicitar, PC irá enviar uma mensagem para liberar o evento transmissor (Algoritmo 7.15). 

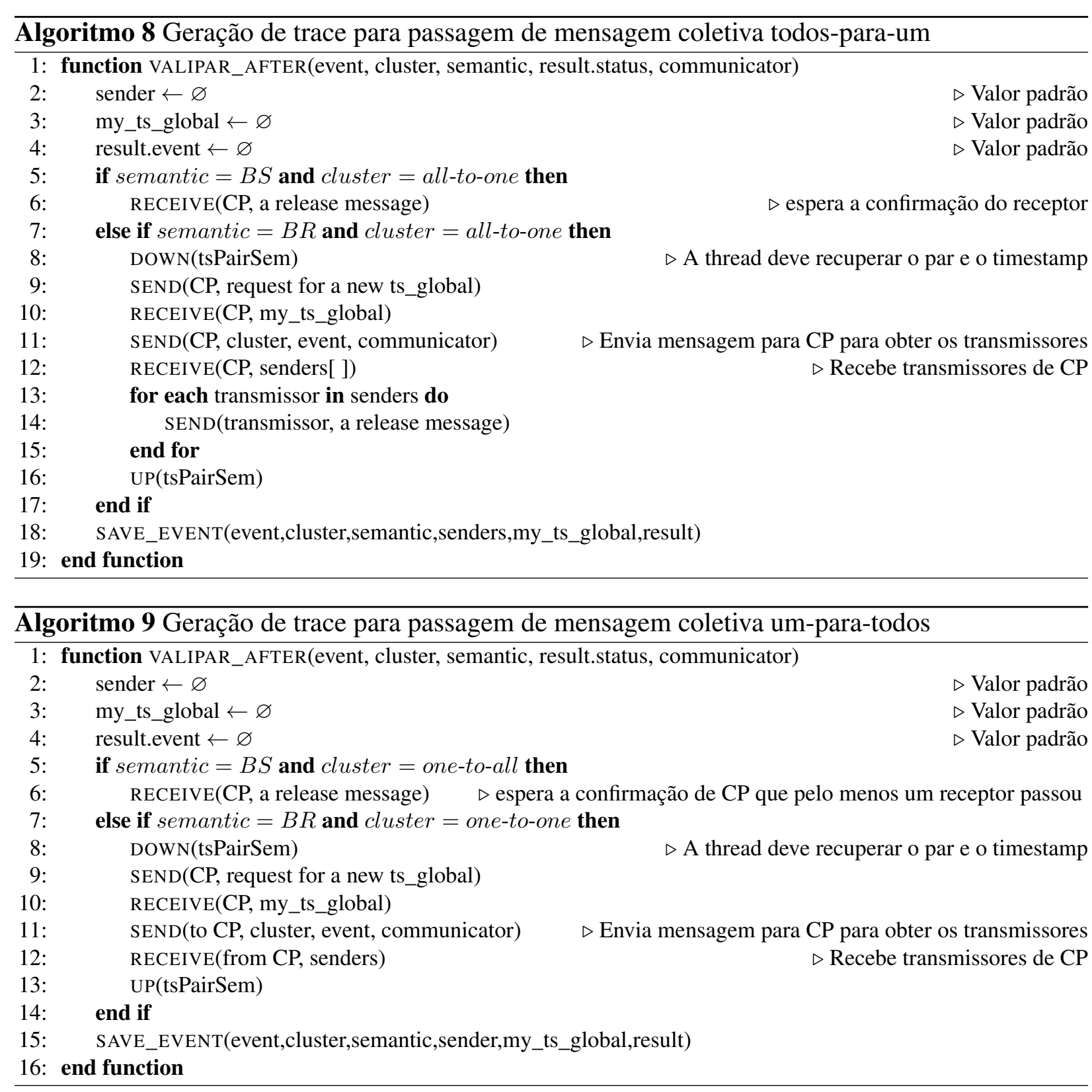

\subsubsection{Execução determinística}

Para reexecutar uma sequência de sincronização de um programa concorrente o modo determinístico deve ser ativado no início da execução para que as funções de controle sejam invocadas antes e depois de cada primitiva (Algoritmo 1). Durante a inicialização, cada thread carrega o conteúdo dos respectivos arquivos de rastro da execução original e inicializa uma variável local que representa o ts_global com valor zero. Esta variável controla o progresso dos eventos receptores.

Antes de um evento receptor ser executado ele verifica se o $t s \_g l o b a l$ correspondente no rastro é maior ou igual ao valor do ts_global da thread. A primitiva de recepção só pode ser executada caso esta condição seja satisfeita; caso contrário a thread irá aguardar até receber uma notificação que o valor do $t s \_g l o b a l$ foi atualizado. Ao receber esta mensagem a thread atualiza o seu $t s \_g l o b a l$ e verifica novamente se a primitiva pode ser executada. 
A função valipar_after, invocada logo após a execução da primitiva de recepção, incrementa o valor do $t s \_g l o b a l$ e o propaga por um broadcasting para todas as threads que estão aguardando, liberando assim o próximo receptor.

Os eventos transmissores têm a sua execução controlada de duas formas: (a) aguardam uma liberação do evento receptor em um receive bloqueante ou (b) são executados conforme uma fila ordenada que representa a ordem em que os eventos ocorreram em um determinado cluster da execução original. O primeiro caso é utilizado para controlar eventos ponto-a-ponto de passagem de mensagem, pois estes eventos podem ser liberados apenas quando o evento receptor estiver pronto, evitando a concorrência; e o segundo caso é utilizado para memória compartilhada e para as primitivas coletivas.

A seguir são discutidos os algoritmos de execução determinística para cada uma das primitivas abordadas.

O Algoritmo 10 apresenta a solução de execução determinística para passagem de mensagem ponto-a-ponto bloqueante. Antes dos eventos transmissores efetuarem a execução da primitiva eles aguardam uma mensagem de confirmação do seu receptor original (Algoritmo 10.5), permitindo que o receptor decida de quem irá receber a mensagem, evitando assim o não-determinismo. Quando o receptor está pronto para executar ( $t s \_g l o b a l$ do evento receptor obtido do rastro original é igual ao $t s \_g l o b a l$ ) uma mensagem é enviada para o transmissor recuperado do rastro (Algoritmo 10.10), liberando-o para executar a primitiva de transmissão. O receptor aguarda uma confirmação do transmissor que a mensagem foi enviada para poder executar a primitiva de recebimento (Algoritmo 10.11), a qual é enviada logo após a execução da primitiva (Algoritmo 10.16).

Além do rastro original, o algoritmo de memória compartilhada bloqueante carrega uma fila para cada cluster, contendo todos os eventos transmissores que ocorreram no mesmo e na mesma ordem em que eles foram executados na execução original. Antes de uma primitiva de transmissão de memória compartilhada ser executada, o evento carregado do rastro será comparado ao topo da fila, se o evento não for igual ao evento do topo, ele irá dormir em uma variável de condição (Algoritmo 11.10); caso ele seja, duas ações serão realizadas após a execução da primitiva: o topo da fila do cluster é movido (Algoritmo 11.23) e todos os eventos transmissores que estiverem aguardando são acordados (Algoritmo 11.24). O processo para os receptores ocorre de forma semelhante ao de passagem de mensagem bloqueante exceto pela liberação do transmissor e pela mensagem de confirmação.

Durante a execução determinística dos eventos de passagem de mensagem não-bloqueantes, os eventos transmissores aguardam a liberação dos receptores originais (Algoritmo 12.6), da mesma forma da passagem de mensagem bloqueante. As primitivas de recepção que não estabeleceram um par de sincronização (estado $=0$ ) são livres para executar, e como os eventos transmissores aguardam liberação, todos os eventos receptores (receive, test e wait) apresentam o mesmo comportamento da execução original. Antes da execução de um evento receptor que estabeleceu a sincronização (estado = 1), uma mensagem é enviada ao transmissor para liberá-lo (Algoritmo 12.12) e uma confirmação é aguardada antes da primitiva de recepção executar (Algoritmo 12.13). 


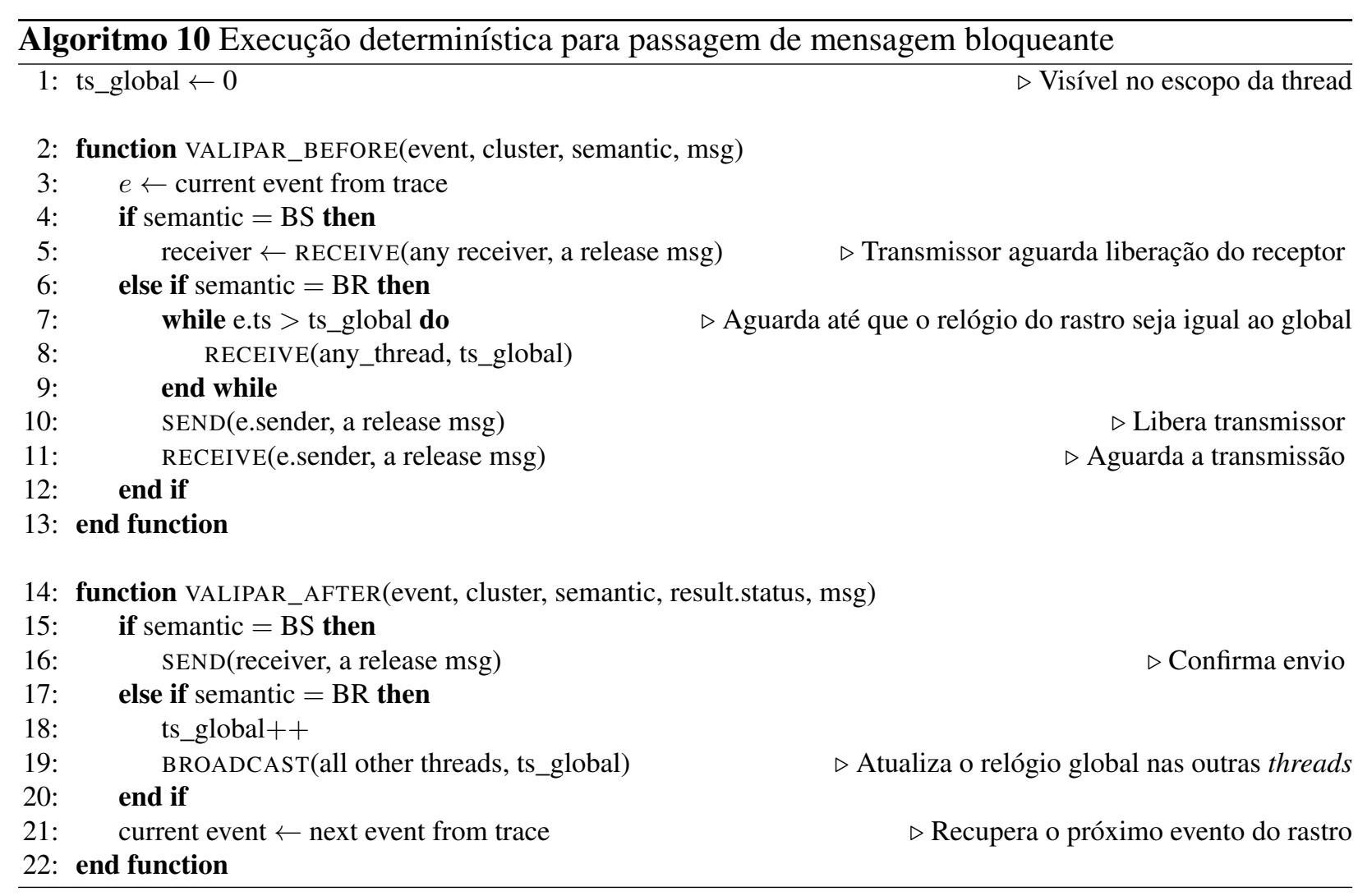

Quando o transmissor é liberado, a primitiva de transmissão é executada e uma confirmação é enviada ao evento receptor (Algoritmo 12.19) que então executa a primitiva de recepção. Esta confirmação é utilizada para que a primitiva de recepção seja executada somente após a transmissão da mensagem, fazendo que ela seja recebida pelo mesmo receptor da execução original. Um evento receptor de passagem de mensagem não bloqueante aguarda o $t s \_g l o b a l$ apenas se ele for o primeiro evento em sua thread.

A execução determinística para primitivas coletivas todos-para-todos (all-to-all) (Algoritmo 13) baseia-se na ordem em que os eventos foram executados dentro do cluster (os eventos não possuem $\left.t s \_g l o b a l\right)$. Portanto, uma fila contendo a ordem dos eventos é carregada em cada thread durante o início da re-execução. Antes de um evento executar ele verifica o topo da fila, caso ele não seja o evento do topo, uma mensagem é enviada para o PC para notificá-lo que este evento aguarda uma alteração no topo da fila (Algoritmo 13.12). Antes do evento que está no topo da fila executar, o topo da fila é movido (Algoritmo 13.9) e uma mensagem é enviada para o PC (Algoritmo 13.16). Ao receber esta mensagem, o PC envia uma mensagem para cada thread que estiver aguardando para que estes eventos tentem executar novamente (Algoritmo 13.13).

A execução determinística para primitivas coletivas um-para-todos e todos-para-um é apresentada no Algoritmo 14. Nestes casos a execução dos eventos transmissores é controlada com o auxílio de PC por meio de uma fila. Cada cluster possui uma fila dos eventos transmissores na mesma ordem em que foram salvos no rastro. Um evento transmissor só pode ser executado se ele estiver no topo desta fila, caso contrário ele aguarda uma notificação de PC que o topo foi movido e que pode tentar novamente. Após a execução de um evento transmissor a fila é movida 


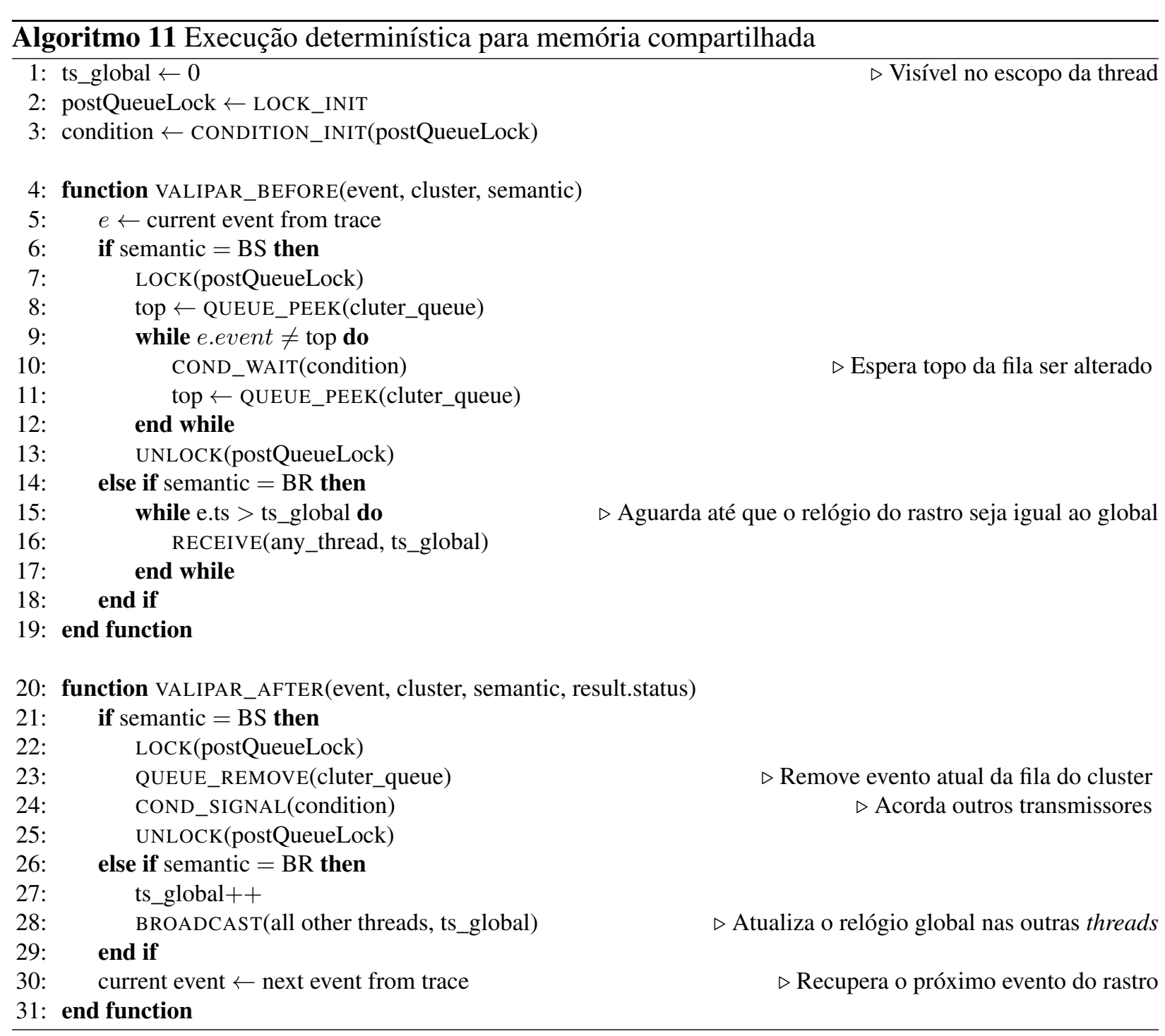

e uma notificação é enviada para PC para que ele libere as threads que estiverem aguardando. Os eventos receptores são controlados pelo $t s \_g l o b a l$ de forma semelhante ao algoritmo de passagem de mensagem bloqueante.

\subsection{Avaliação e análise dos resultados}

Um protótipo dos algoritmos apresentados foi desenvolvido em Java para avaliar: (a) se os algoritmos são capazes de reexecutar um programa concorrente deterministicamente; (b) o custo (overhead) adicionado pela execução determinística; e (c) o tamanho dos arquivos de rastros gerados.

Cinco microbenchmarks foram utilizados durante o desenvolvimento e a avaliação dos algoritmos. Estes possuem características pontuais e validam o comportamento dos algoritmos para cada primitiva específica, sendo que cada microbenchmark possui apenas um tipo de primitiva. A Tabela 4.3 apresenta os seguintes dados dos microbenchmarks utilizados: paradigma (PM - 


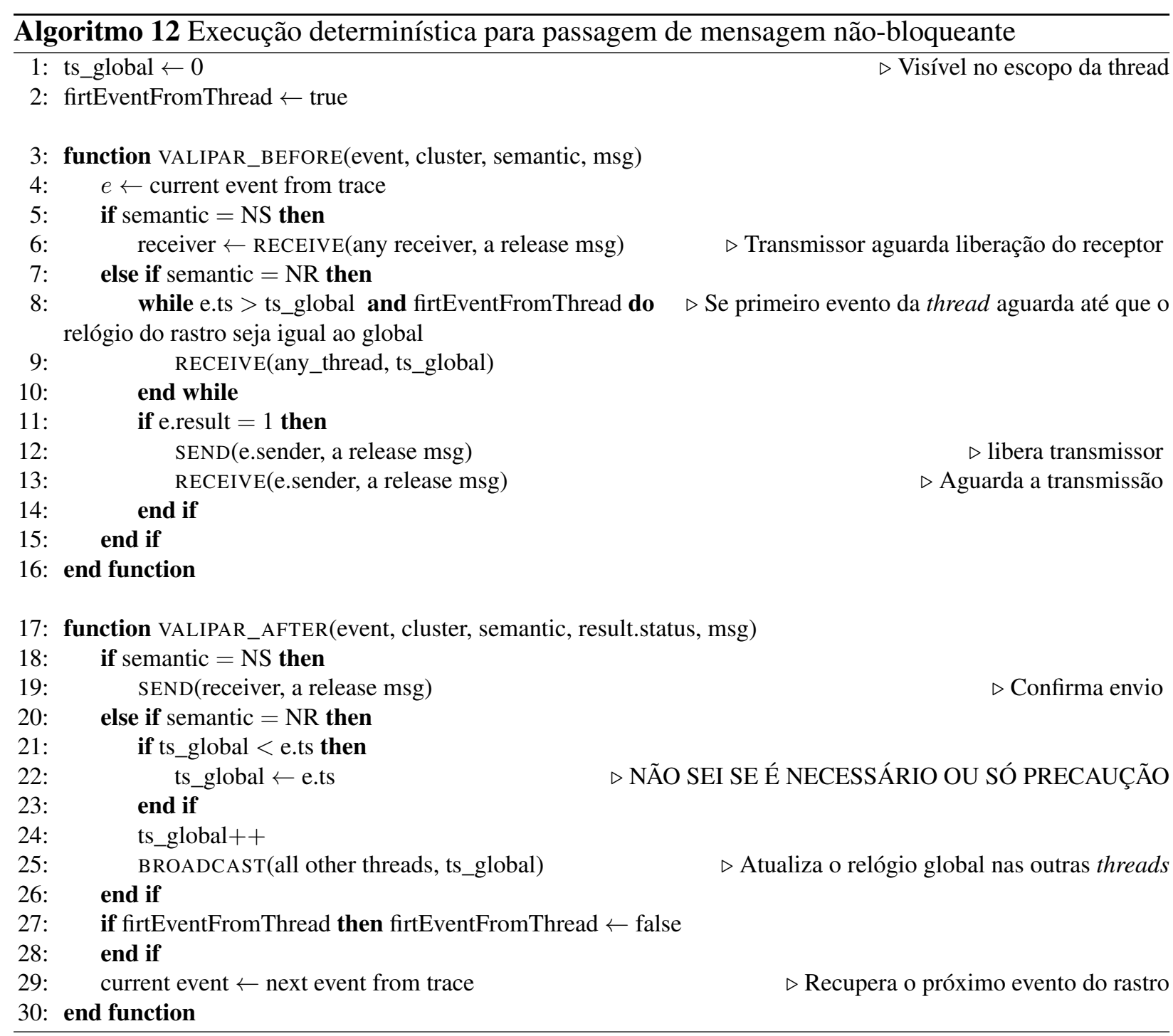

Passagem de mensagem; MC - Memória compartilhada), semântica (P2P - ponto-a-ponto; COL - coletiva; BQ - Bloqueante; NBQ - Não-Bloqueante; ATA - Todos-para-todos; OTA - Um-paratodos), número de processos, número de threads, eventos de transmissão, eventos de recepção, eventos transmissor-receptor, linhas de código e complexidade ciclomática. No caso de Java não foram encontradas primitivas de sincronização que utilizem a semântica todos-para-um.

Tabela 4.3: Microbenchmarks utilizados durante a implementação e validação dos algoritmos.

\begin{tabular}{lclccccccc}
\hline & Paradig. & Semântica & Proc. & Thr. & Trans. & Recept. & Trans-Recept & Loc & CC \\
\hline BMP & PM & P2P/BQ & 3 & 3 & 4 & 4 & 0 & 66 & 1,2 \\
SM & MC & P2P/BQ & 1 & 3 & 9 & 8 & 0 & 42 & 1,0 \\
NMP & PM & P2P/NBQ & 3 & 3 & 3 & 3 & 0 & 99 & 2,8 \\
ATA & MC & COL/ATA & 1 & 4 & 0 & 0 & 6 & 65 & 1,5 \\
OTA & PM & COL/OTA & 4 & 4 & 2 & 4 & 0 & 47 & 2,5 \\
\hline
\end{tabular}



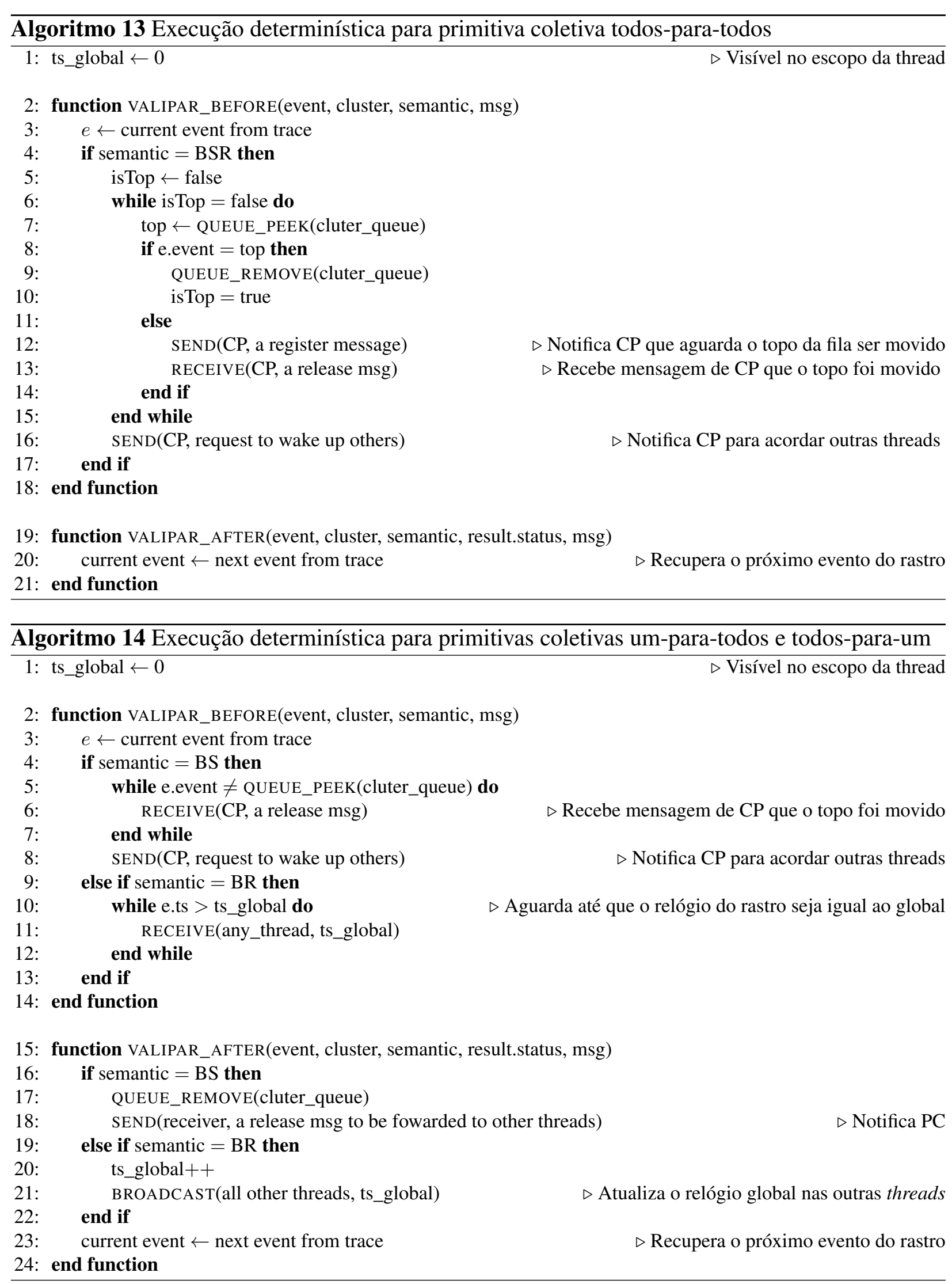

Outros quatro benchmarks maiores e com uma combinação de primitivas também foram utilizados. Foram eles: produtor-consumidor (PC), prime-server (PS), multiplicação de matrizes $2 \times 2$ 
(MT) e Token-Ring (TR), sendo que PC possui apenas primitivas de memória compartilhada e os outros três possuem ambos os paradigmas (passagem de mensagem e memória compartilhada); PS e TR possuem primitivas ponto-a-ponto bloqueante e não-bloqueante e o restante utiliza primitivas bloqueantes. O benchmark TR, em particular, utiliza as seguintes primitivas: passagem de mensagem bloqueante e não-bloqueante, memória compartilhada (semáforos), barreira (all-toall) e broadcast (one-to-all). A Tabela 4.4 apresenta as principais características destes quatro benchmarks.

Tabela 4.4: Características dos quatro benchmarks utilizados para avaliar a geração de rastro e execução determinística. São apresentadas as quantidades de: processos, threads, nós transmissores, nós receptores, nós transmissores/receptores (Transm/Recpt), linhas de código (LOC) e complexidade ciclomática (CC).

\begin{tabular}{cccccccc}
\hline & Processos & Threads & Transmissores & Receptores & Transm/Recpt & Loc & CC \\
\hline PC & 1 & 5 & 19 & 16 & 0 & 140 & 1,2 \\
PS & 4 & 7 & 29 & 18 & 0 & 210 & 1,5 \\
MT & 5 & 13 & 37 & 30 & 0 & 227 & 1,4 \\
TR & 3 & 7 & 25 & 17 & 20 & 296 & 2,6 \\
\hline
\end{tabular}

Os benchmarks foram executados em um computador com um processador Intel Core i7 36100M 2.3GHz com 8GB de memória em um sistema Ubuntu Server 14.04 utilizando uma Máquina Virtual Java OpenJDK 1.7.0_55. Cada benchmark foi executado 30 vezes não-deterministicamente (livre) e 30 vezes deterministicamente. Em cada execução foram coletados o tempo de resposta do benchmark, a quantidade de arquivos de rastro gerados e o tamanho dos arquivos de rastro (em bytes).

Todas as execuções determinísticas geraram arquivos de rastro equivalentes aos respectivos arquivos de rastro gerados pelas execuções livres.

A Tabela 4.5 apresenta os resultados obtidos destacando o custo adicionado pela execução determinística. Como pode ser observado nos dados apresentados, o custo adicional ao tempo de resposta pela execução determinística ficou entre 154\% e 307\% em relação à execução livre. Para microbenchmarks o overhead ficou abaixo de $173 \%$ e para os benchmarks o custo foi um pouco mais alto, entre $244 \%$ e $307 \%$. Estes resultados eram esperados e demonstram que o custo sobre o tempo de resposta se torna alto conforme a quantidade de primitivas aumenta. Apesar desse aumento no tempo de resposta, a geração de arquivos de rastro e as execuções determinísticas cumpriram ambas o seu objetivo que é descrever o comportamento da execução concorrente de uma aplicação e permitir que a mesma possa ser repetida, com vistas ao teste estrutural de programas concorrentes. Ressalta-se aqui que essa sobrecarga considera rastros com informações sobre todos os nós executados e as definições e usos de variáveis. Sem tais informações a sobrecarga seria menor. 
Tabela 4.5: Overhead da execução determinística e tamanho dos rastros para os benchmarks utilizados.

\begin{tabular}{lccccc}
\hline & Ex. livre (ms) & Ex. determ. $(\mathbf{m s})$ & Overhead & Rastro (quantidade) & Rastro (bytes) \\
\hline BMP & 149,63 & 249,87 & $166,99 \%$ & 6 & 12198 \\
SM & 117,73 & 240,63 & $204,39 \%$ & 7 & 9418 \\
NMP & 173,10 & 358,30 & $206,99 \%$ & 6 & 20631 \\
ATA & 108,80 & 167,93 & $154,35 \%$ & 2 & 1839 \\
OTA & 182,60 & 315,03 & $172,53 \%$ & 9 & 22526 \\
\hline PC & 147,20 & 360,57 & $244,95 \%$ & 13 & 24622,8 \\
PS & 219,70 & 642,30 & $292,35 \%$ & 17 & 71499 \\
MT & 296,00 & 887,37 & $299,79 \%$ & 30 & 113671 \\
TR & 237,67 & 729,83 & $307,08 \%$ & 21 & 87384 \\
\hline
\end{tabular}

A Figura 4.3 apresenta uma comparação entre os tempos de resposta médios para a execução não-deterministica (livre) e a execução determinística com um intervalo de confiança de 95\%, este calculado com base em uma distribuição normal.

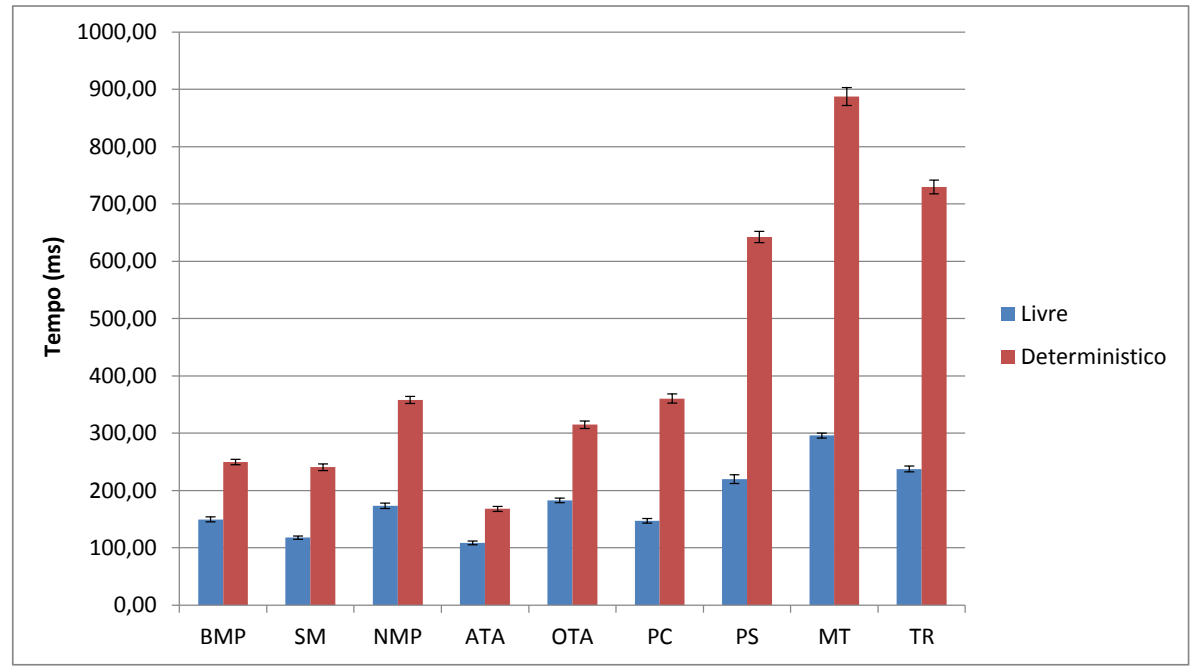

Figura 4.3: Tempo médio de resposta das execuções livre e determinística para os benchmarks.

Como pode ser visto na Figura 4.4(a), o tamanho do arquivo de rastro está fortemente relacionado à quantidade de primitivas contidas nos benchmarks. Um segundo fator que influencia no tamanho do rastro é a quantidade de linhas de código do benchmark. Esta comparação pode ser visualizada na Figura 4.4(b). Isto ocorre pois outros eventos como o início de um nó, definições e uso de variáveis também são fornecidos pelo instrumentador da ValiPar (ValiInst) e também são contabilizados. 


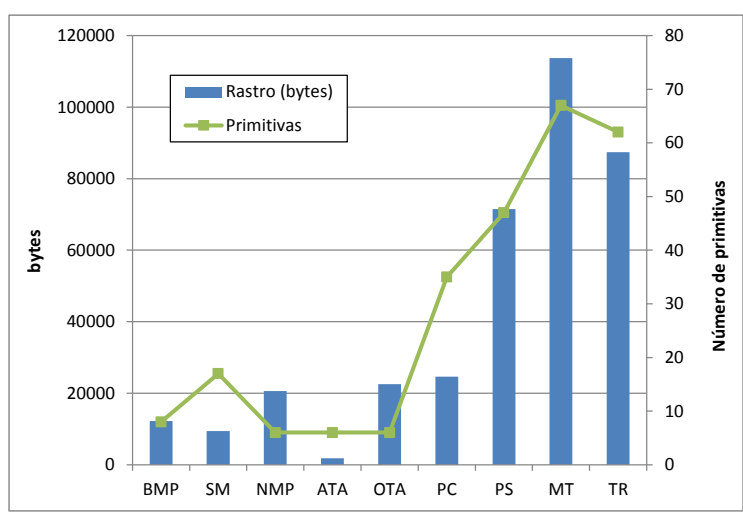

(a)

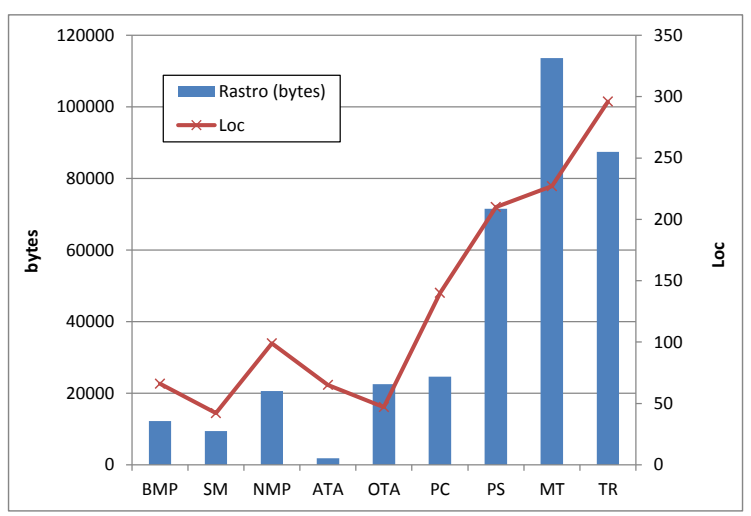

(b)

Figura 4.4: Tamanho do rastro em relação a (a) quantidade de primitivas e (b) quantidade de linhas de código.

\subsection{Considerações finais}

Neste capítulo foram apresentados algoritmos para a geração de arquivo de rastro e para execução determinística para seis tipos de primitivas de sincronização: passagem de mensagem pontoa-ponto bloqueante e não-bloqueante, memória compartilhada bloqueante (semáforo), primitivas coletivas um-para-todos, todos-para-um e todos-para-todos. Além disto, os algoritmos podem ser utilizados quando estes diferentes paradigmas são usados em programas concorrentes ao mesmo tempo.

Para todos os experimentos realizados os algoritmos cumpriram seu objetivo de reexecutar um programa concorrente de forma determinística. Além disto, informações como os pares de sincronização e a ordenação dos eventos são fornecidos nos arquivos de rastro. Tais informações são importantes para o teste estrutural de programas concorrente durante a avaliação da cobertura das arestas de sincronização e para determinar a definição e o uso de variáveis compartilhadas.

Os experimentos realizados demonstram que o overhead da execução determinística e o tamanho dos arquivos de rastro crescem proporcionalmente à quantidade de primitivas utilizadas no programa concorrente. Embora ainda custosas, tanto a geração dos arquivos de rastro quanto a execução determinística agregam uma série de benefícios. A execução determinística será aplicada diretamente no teste estrutural de programas concorrentes, permitindo a re-execução de um defeito revelado e ajudando na atividade de depuração. Ainda no contexto do teste estrutural de programas concorrentes, a execução determinística também será utilizada pela geração automática de novas sequências de sincronização (ou variantes), permitindo que novas sincronizações de um programa concorrente sejam cobertas a partir de um arquivo de rastro. 



\section{Geração Automática de Pares de Sincronização}

\subsection{Considerações iniciais}

Este capítulo apresenta a geração automática de pares de sincronização em programas concorrentes para aumentar a taxa de cobertura dos mesmos. Aumentando a taxa de cobertura com foco nos pares de sincronização, espera-se revelar defeitos difíceis de serem revelados em programas concorrentes. O capítulo apresenta uma visão geral desse tema, descrevendo os principais trabalhos relacionados encontrados na literatura. Na sequência é apresentada a proposta de um novo algoritmo para geração automática de pares de sincronização em programas concorrentes com passagem de mensagem e memória compartilhada. Este novo algoritmo é baseado em teste de prefixo e combina o teste determinístico com o não-determinístico, na qual a seleção dos pares é guiada por um modelo estático. A avaliação feita por meio de experimentos considerou sete diferentes benchmarks, na qual duas políticas para a geração dos pares de sincronização foram analisadas. Os resultados obtidos mostram que os algoritmos propostos foram capazes de obter $100 \%$ da cobertura de arestas de sincronização para os benchmarks utilizados.

\subsection{A geração automática de pares de sincronização}

O teste estrutural visa à cobertura de elementos requeridos gerados a partir de critérios de teste. Acredita-se que quanto maior for a cobertura de um programa, maiores são as chances deste 
programa conter menos defeitos. No contexto de programas sequenciais, o teste estrutural tem por objetivo melhorar a qualidade do conjunto de casos de teste propondo critérios que aumentem a cobertura de instruções, desvios condicionais e definição/uso de variáveis do programa em teste, aumentando assim a probabilidade de revelar defeitos.

O teste estrutural de programas concorrentes acrescenta critérios específicos à cobertura das primitivas de sincronização entre processos e, para tanto, deve considerar igualmente o não determinismo associado a este contexto. Souza et al. (2013) propõem o critério all-sync-edges (todasarestas-sincronização) cujo objetivo é cobrir todas as arestas de sincronização de um programa concorrente. Os elementos requeridos para este critério são gerados a partir de um produto cartesiano dos eventos transmissores pelos eventos receptores, dentro de um mesmo cluster de sincronização.

A Figura 5.1 apresenta um diagrama espaço-tempo da execução de um programa concorrente composto de quatro processos $(p 0, p 1, p 2 e p 3)$ e suas possíveis sincronizações. Ele se comunica por passagem de mensagem contendo quatro transmissores ( $t 0, t 1, t 2$ e $t 3)$ e quatro receptores $(r 0, r 1, r 2$ e $r 3)$. As arestas tracejadas representam as sincronizações estabelecidas para um transmissor e um receptor. As setas sólidas verticais indicam o tempo decorrido na execução. Outras possíveis sincronizações seriam $t 0 \rightarrow r 1, t 1 \rightarrow r 0, t 2 \rightarrow r 3$ e $t 3 \rightarrow r 2$. Uma boa ferramenta de testes para programas concorrentes deveria exercitar (testar) cada um destes pares de sincronização, no mínimo uma vez, maximizando as chances de se revelar um defeito.

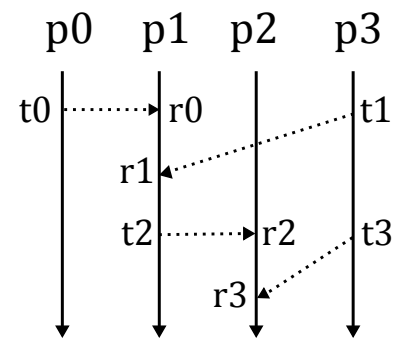

(a)

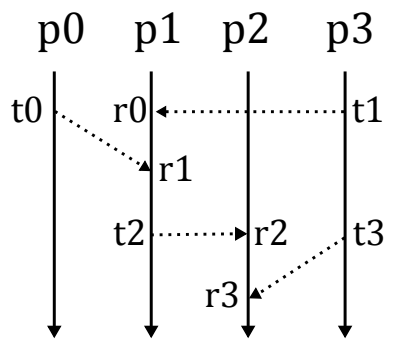

(b)

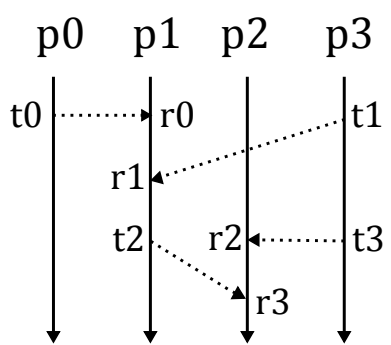

(c)

Figura 5.1: Diagrama espaço-tempo (setas sólidas verticais) de um programa concorrente com passagem de mensagem e suas possíveis sincronizações (setas tracejadas). Adaptado de Lei e Carver (2006).

Sabe-se que explorar o conjunto de todos os possíveis pares de sincronização (all interleavings) é impraticável, exceto para pequenos programas (Eytani et al., 2003). Por isso diversas técnicas de se explorar diferentes sequências de sincronização de um programa concorrente são propostas, a fim de relevar defeitos com a atividade de teste.

Umas das maneiras de se abordar o comportamento não-determinístico durante o teste de programas concorrentes é executar o programa com as mesmas entradas durantes várias vezes e esperar que os defeitos sejam expostos no mínimo em uma execução. Este tipo de teste não-controlado é chamado de teste não-determinístico (non-deterministic testing). 
Há diversas técnicas que podem ser utilizadas para aumentar a probabilidade de se exercitar diferentes pares de sincronizações durante o teste não-determinístico. Uma delas é alterar o algoritmo de escalonamento do sistema operacional (SO), como por exemplo, alterar o quantum utilizado por um escalonamento round-robin ou alterar a ordem em que os processos na fila de prontos são selecionados para execução. Esta abordagem pode aumentar a probabilidade de cobrir diferentes sincronizações (Hwang et al., 1995), contudo, é uma solução inviável em sistemas operacionais comerciais pela dificuldade de se alterar códigos do SO.

Uma segunda técnica para aumentar a probabilidade de se gerar diferentes interleavings é a inserção de ruídos em pontos estratégicos do programa concorrente, tais como a inserção de sleeps com o tempo escolhido aleatoriamente ou chamadas ao escalonador da Máquina Virtual Java (JVM) para tomada de decisões (Edelstein et al., 2001; Stoller, 2002; Musuvathi et al., 2008). Esta técnica força a troca de contexto e adota o escalonamento das threads indiretamente. O objetivo é garantir uma probabilidade não-zero para exercitar uma sequência de sincronização arbitrária enquanto se adiciona ou remove atrasos na execução do programa.

O teste não-determinístico de programas concorrentes é simples de ser implantado, porém pode ser ineficiente, uma vez que, a execução de um mesmo conjunto de sincronizações pode ocorrer diversas vezes enquanto outras nunca sejam exercitadas.

Uma segunda maneira de lidar com o não-determinismo é o teste determinístico. Este tipo de teste permite a re-execução determinística (replay) de um programa concorrente dado um caso de teste e uma sequência de sincronização. Por se tratar de uma execução determinística, comparamse os resultados esperados com a saída obtida do programa e caso eles sejam diferentes, um defeito pode ter sido detectado. Este tipo de teste também permite que o testador selecione um caminho de sincronização de acordo com a implementação e especificação do programa concorrente (Taylor et al., 1992), a fim de aumentar a cobertura das sincronizações.

A execução determinística de programas concorrentes pode ocorrer pela disponibilização de bibliotecas que suportem a geração de rastro e a re-execução determinística, substituindo as primitivas originais da linguagem (Carver e Lei, 2010a). Também podem ocorrer automaticamente pela transformação do programa concorrente, permitindo sua re-execução (Tai et al., 1991) como descrito na Seção 4.4; além das abordagens baseadas em implementação que alteram o compilador, as bibliotecas de execução e máquinas virtuais (Choi e Srinivasan, 1998; Konuru et al., 2000).

O teste determinístico possui um problema adicional que é a seleção da sequência de sincronização a ser utilizada nos testes (Hwang et al., 1995). Uma das possíveis soluções é gerar caminhos de sincronização a partir de um grafo de fluxo (extraído estaticamente do programa concorrente) e um grafo de sincronizações (Rendezvous Graph - extraído dinamicamente). Heurísticas são aplicadas com base nestes grafos para a seleção de caminhos factíveis baseados em critérios de cobertura de nós e arestas de sincronização (Hsu e Chung, 1992; Yang e Chung, 1990). As soluções para o teste determinístico exigem um esforço considerável para derivar sequências de sincronizações e para determinar sua factibilidade. 
O custo do teste determinístico pode ser reduzido por meio da combinação da abordagem não-determinística com o mesmo (Carver e Tai, 2005). Três estratégias destacam-se aqui: (a) aplicar o teste não determinístico até alcançar um determinado nível de cobertura e então aplicar o teste determinístico para alcançar um nível de cobertura maior; (b) as sequências de sincronização coletadas durante o teste não-determinístico podem ser modificadas para produzir novas sequências para o teste determinístico (esta abordagem é mais simples do que gerar sequências do zero); e (c) permitir que o teste não-determinístico inicie a partir de um estado específico do programa, diferente do inicial, esta técnica é chamada de teste baseado em prefixo (prefix-based testing).

O teste baseado em prefixo utiliza uma sequência de sincronização inicial que força a execução do programa concorrente até um determinado ponto do programa e o restante do teste é executado não-deterministicamente. Esta estratégia é uma parte importante do teste de alcançabilidade (reachability testing) (Lei e Carver, 2006). O teste de alcançabilidade é uma forma sistemática de exercitar todas as possíveis sincronizações de um programa concorrente para um dado caso de teste.

Lei e Carver (2006) derivam sequências de sincronização dinamicamente durante o tempo de execução (on-the-fly). Durante a execução do teste, os eventos são rastreados e analisados para derivar um prefixo de uma sequência de sincronização que são variantes de disputa (race variants), ou apenas variantes, do rastro gerado. As execuções das variantes também são rastreadas e analisadas para gerar novas variantes e assim por diante até que todas as possíveis variantes tenham sido executadas (considerando que o conjunto de sincronizações do programa concorrente é finito, tendo-se como base um dado de teste). A derivação realizada durante tempo de execução gera apenas sequências executáveis.

Ferramentas de teste de software devem apoiar esta atividade, permitindo três atividades fundamentais: registrar quais foram os pares de sincronização exercitados em uma execução qualquer, i.e., gerar arquivos de rastro para uma variante dos pares de sincronização; permitir a execução determinística de um programa concorrente, de modo a forçar que novas variantes sejam exercitadas e, finalmente, determinar quais seriam estes possíveis pares de sincronização em um dado programa concorrente. As duas primeiras atividades, geração de arquivos de rastro e execução determinística, foram descritas no Capítulo 4. Com o suporte destas duas atividades, este capítulo propõe algoritmos para a geração automática de variantes, i.e., para a execução de programas concorrentes que exercitam automaticamente diferentes pares de sincronização com um mesmo dado de teste.

Não foram encontradas na literatura propostas que considerem a geração automática de pares de sincronização para o teste estrutural de programas concorrentes, estes desenvolvidos sob os paradigmas de passagem de mensagem e memória compartilhada simultaneamente. 


\subsection{Algoritmos para a geração de variantes}

A técnica proposta neste trabalho deriva os pares de sincronização baseando-se em um modelo estático do programa concorrente em teste. Esta técnica foi utilizada para guiar um teste estrutural baseado em prefixo e inspirado em Lei e Carver (2006). A execução determinística proposta neste trabalho (Capítulo 4) foi adaptada para controlar parcialmente alguns eventos da execução concorrente e, além disso, também foram criados algoritmos de geração de variantes para exercitar novos pares de sincronizações. Os algoritmos desenvolvidos consideram o uso isolado ou concomitante de primitivas de memória compartilhada (semáforos) e de passagem de mensagens ponto-a-ponto.

A execução determinística parcial faz-se necessária porque ao exercitar uma nova sincronização, os eventos posteriores também poderão ter seus pares alterados e, dessa forma, o restante do programa deve executar livremente.

Esta nova execução recebe um arquivo de rastro contendo apenas os eventos que devem ser executados deterministicamente. Cada thread deve carregar os eventos que lhe compete, controlando sua execução conforme os algoritmos descritos no Capítulo 4. A partir do momento que não há mais eventos no arquivo de rastro a serem executados deterministicamente, as threads do programa concorrente devem sincronizar em uma barreira e prosseguir não deterministicamente. Esta sincronização é necessária para que eventos livres não afetem eventos que ainda devem ser controlados mas que não foram executados. O rastro parcial deve organizar os eventos de maneira a cobrir a nova sincronização desejada e determinar o ponto de sincronização de cada thread na barreira.

Os arquivos de rastros parciais são derivados do rastro de uma execução livre e estas derivações são chamadas de variantes. Cada variante visa a troca de apenas um par de sincronização por vez, selecionando um novo transmissor para cobrir uma sincronização ainda não realizada. A escolha de um novo transmissor é realizada com base em duas políticas distintas.

Os elementos requeridos do critério all-sync-edge são gerados com base em um conjunto de informações extraídas do programa concorrente em teste, por meio de uma análise estática. Eles são resultados do plano cartesiano de todos os eventos transmissores com todos os eventos receptores obedecendo as restrições dos clusters citados na Seção 4.4. Os módulos ValiInst e ValiElem da ferramenta Valipar foram utilizados para obter o modelo estático do programa concorrente e os elementos requeridos, respectivamente.

As variantes são geradas para cada receptor na ordem cronológica da execução base, i.e., considerando os arquivos de rastro de uma execução inicial. Para tanto os eventos de sincronização vindos de todas as threads devem ser ordenados e adicionados em uma única fila. O Algoritmo 15 apresenta o método utilizado para realizar a ordenação de tais eventos. Este algoritmo assume que o parâmetro receivers possui todos os eventos receptores da execução base, ordenados pelo relógio lógico e que o parâmetro transmitters possui todos eventos transmissores sequencialmente ordenados por threads $\left(p_{0} t_{0} e_{0}, p_{0} t_{0} e_{1}, p_{0} t_{1} e_{0}, p_{0} t_{1} e_{1}, p_{1} t_{0} e_{0}, \ldots\right)$. Para cada evento da lista de receptores 
ordenados, o algoritmo insere na lista sorted_events todos os eventos transmissores que antecedem seu transmissor original, pertencentes à mesma thread, inclusive o transmissor (Algoritmo 15.11). Posteriormente são inseridos todos os transmissores que antecedem o evento receptor (Algoritmo 15.25) e então, finalmente, o evento receptor é inserido na nova lista (Algoritmo 15.32). Após a inserção de todos os eventos receptores na nova lista, buscam-se na execução base eventuais transmissores sem seus respectivos receptores. Se existirem, tais transmissores são adicionados ao final da lista ordenada (Algoritmo 15.34).

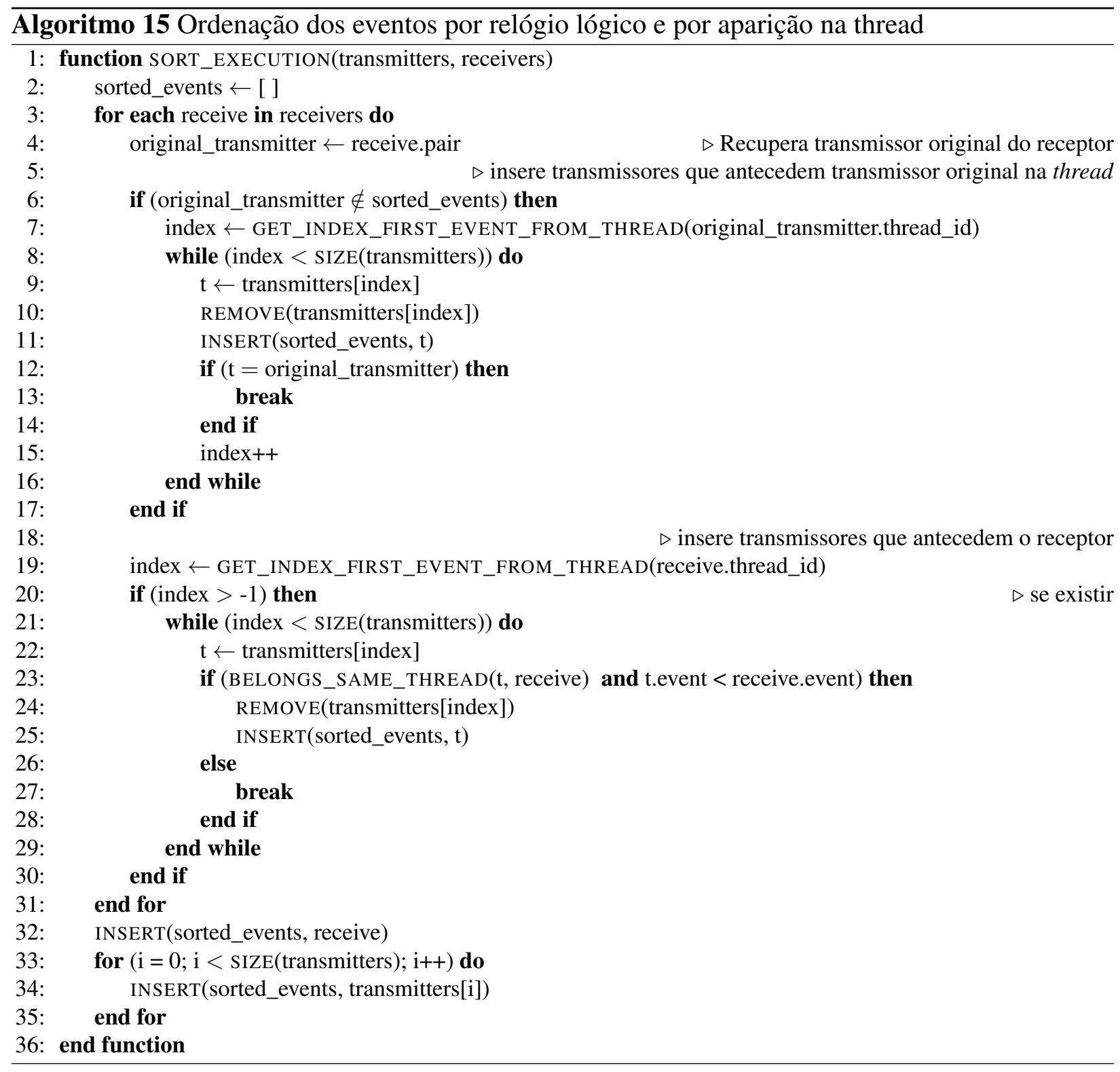

Considerando uma fila contendo todos os eventos de sincronização ordenados de uma execução, o Algoritmo 16 verifica todos os pares ainda não cobertos nos elementos requiridos para cada evento receptor. O Algoritmo 16 apresenta a busca de novos transmissores para um dado evento receptor e a posição inicial da busca. A partir da posição inicial da busca (start_search_position), este algoritmo procura na lista de eventos ordenados um evento transmissor que seja futuro 
ao evento receptor; que não pertença à mesma thread do receptor e que seja um possível par de sincronização (exista nos elementos requeridos e pertença ao mesmo cluster).

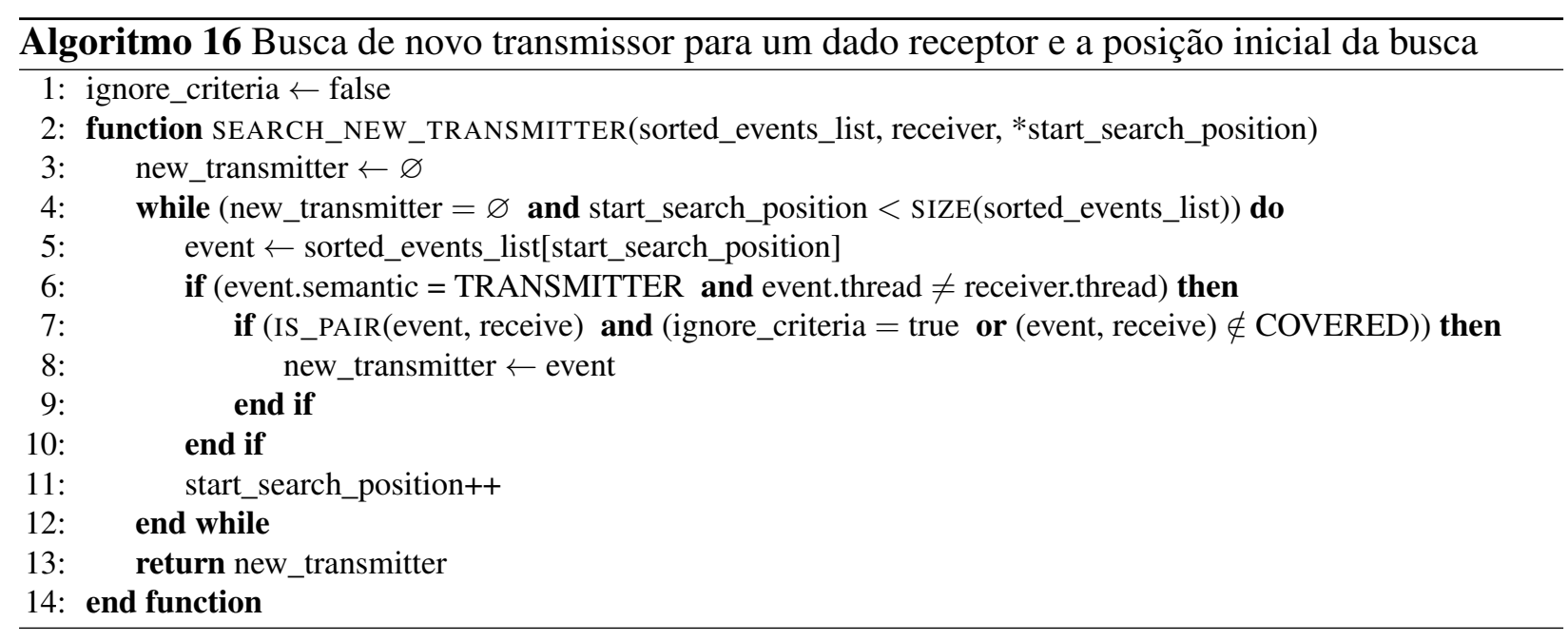

Conforme citado antes, duas políticas de seleção de novos transmissores foram desenvolvidas: a primeira delas descarta um novo transmissor caso a aresta de sincronização já tenha sido coberta; a segunda política gera todos os pares possíveis, independente de sua cobertura (Algoritmo 16.7). A primeira abordagem gera um número menor de variantes reduzindo o custo de execução, porém pode impedir que outros pares sejam cobertos ao derivar uma próxima execução. O custo da segunda abordagem é maior, mas não impede que eventos futuros em uma próxima geração de variantes sejam cobertos.

Um exemplo da limitação da primeira abordagem ocorre quando existem semáforos dentro de laços de repetição e alguns elementos requeridos necessitam seguir um caminho de pares de sincronização específico para ser executável. Por exemplo, considerando um programa produtor consumidor representado pela Figura 5.2 (algumas sincronizações foram omitidas para reduzir o espaço), deseja-se cobrir o par $s 3 \rightarrow r 4$ representado pela aresta tracejada. Para que esta sincronização seja coberta é necessário que o semáforo full tenha no mínimo dois tokens ( $s 1$ e $s 2$ ); que o semáforo $m t$ (mutex) tenha 1 token; e que a thread consumidora ( $t 1)$ execute a repetição duas vezes consecutivas. Uma avaliação da influência das políticas será apresentada na Seção 5.4.

O Algoritmo 17 apresenta a geração de variantes. Para um dado receptor e novo transmissor selecionado (17.11) uma fila (variant) é criada (17.10). Nesta fila são adicionados todos os eventos da fila de eventos ordenados (sorted_events) até encontrar o receptor (ainda não-incluso na fila) (17.17). O primeiro evento da thread do transmissor é buscado e a partir dele os eventos são adicionados até que o novo transmissor seja encontrado (inclusive) (17.23). Por fim, o receptor é adicionado na fila (17.30).

Após estes passos, algumas verificações e possíveis correções são necessárias. A primeira delas é apresentada no Algoritmo 17.32. A função fix_transmitters procura por dois transmissores consecutivos que pertençam ao mesmo cluster, p.e. $[t 1, t 2, r 1]$ ( $\mathrm{t}$ - transmissor, $\mathrm{r}$ - receptor). Se a execução original já apresentava este padrão, nenhuma correção é realizada; caso contrário, (a) 


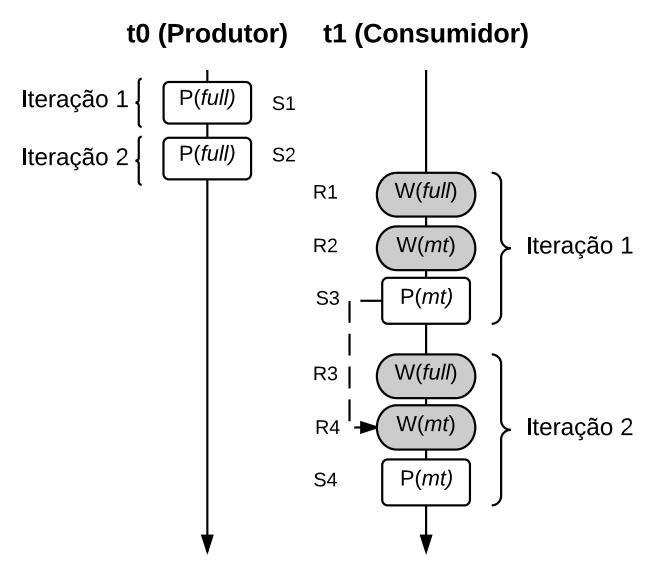

Figura 5.2: Exemplo da limitação da política de escolha de novos transmissores, considerando apenas pares ainda não cobertos.

se os transmissores $t 1$ e $t 2$ pertencem à mesma thread significa que o evento $t 2$ depende de $t 1 \mathrm{e}$ $t 2 \rightarrow r 1$ não poderá formar um par de sincronização, portanto esta variante é descartada; ou (b) se os transmissores $t 1$ e $t 2$ pertencem a threads distintas significa que o evento $t 1$ ficará sem um par de sincronização que o libere e esta variante causaria um deadlock supondo que ela seja uma possível sincronização, portanto o evento $t 1$ é removido.

A segunda verificação procura pelo padrão receptor seguido de receptor $[t 1, r 1, r 2]$ (Algoritmo 17.33). Isto significa que o evento $r 2$ não possui um par e portanto essa situação causaria um deadlock. Neste caso o transmissor original de $r 2$ é obtido e inserido entre os receptores. Caso este transmissor já tenha sido adicionado $r 2$ ficará sem um par de sincronização e portanto a variante será descartada.

Caso o evento receptor que teve seu transmissor trocado seja uma passagem de mensagem, o transmissor original deve ser removido da fila variant (Algoritmo 17.38). Isto deve acontecer pois o transmissor original ocorreu antes no novo transmissor (que é um evento futuro do receptor) na execução base, dessa forma, o transmissor original é removido para que o novo transmissor tenha a chance de formar um par de sincronização com o receptor.

A última verificação procura por eventos receptores que não possuem um evento transmissor e adicionam o par original destes receptores e todos os eventos que os antecedem na thread. Isto se faz necessário porque eventos receptores sem um par de sincronização irão bloquear a execução causando um deadlock na variante. Assim, o objetivo do Algoritmo 18 é resolver as dependências dos pares originais de sincronização destes receptores. Para isto, uma tabela hash é utilizada (transmitters_cluster), na qual cada cluster possui uma lista de eventos transmissores. Conforme a fila variant é percorrida, os transmissores são adicionados à fila do cluster (18.11) e os receptores os removem da fila do cluster (18.15). Caso seja encontrado um receptor sem um evento transmissor (fila de seu cluster esteja vazia), o par original deste receptor e todos os eventos que o antecedem na thread são adicionados na posição do receptor (18.29). Caso ainda não tenham 


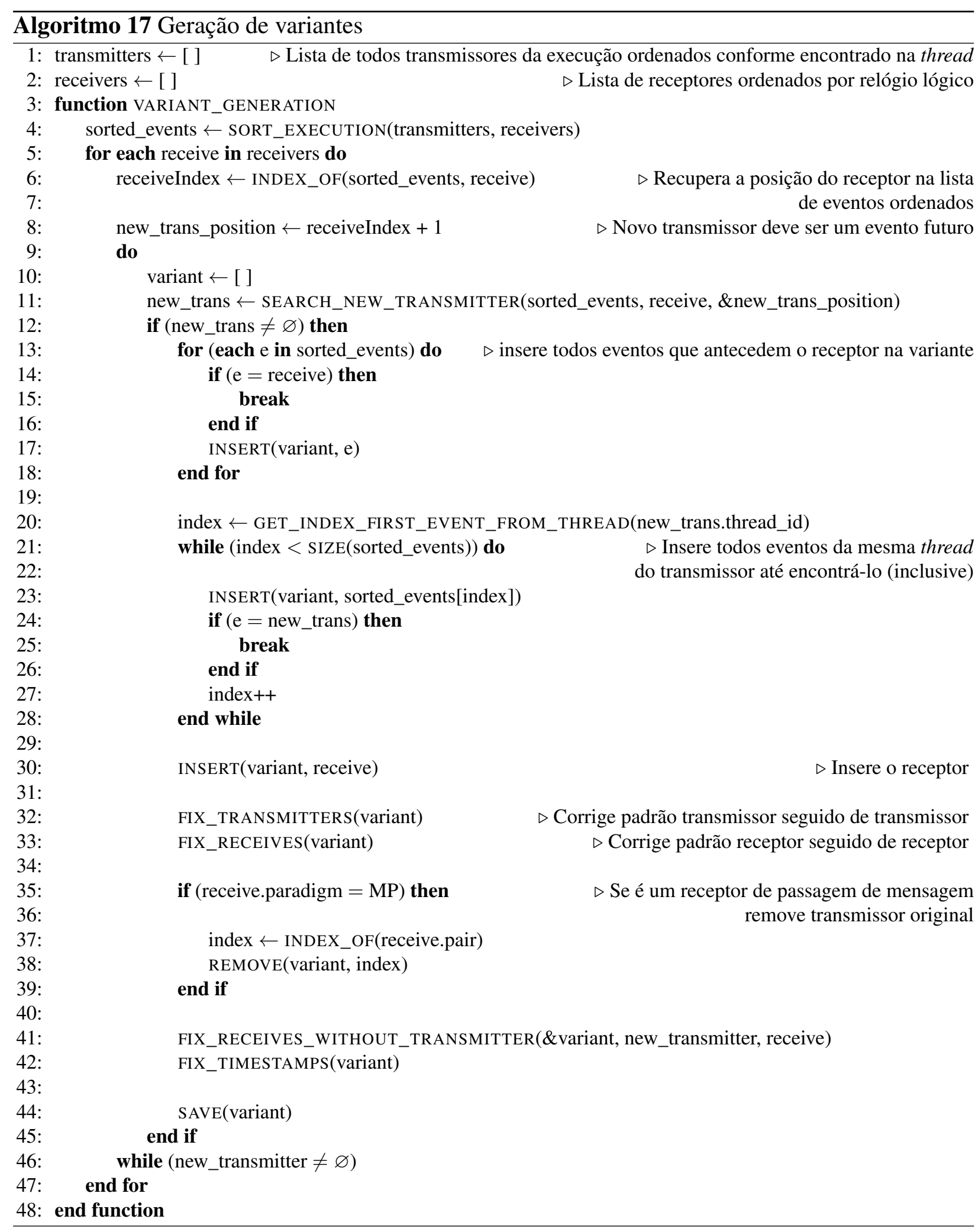

sido, o ponteiro é decrementado para verificar os novos eventos adicionados (18.31). Caso estas dependências já tenham sido adicionadas, a variante é descartada (18.26). Se o transmissor a ser buscado pertencer à mesma thread do novo transmissor ou do receptor que teve o par trocado a variante é descartada. Isto é necessário pois uma dependência cíclica é criada. 


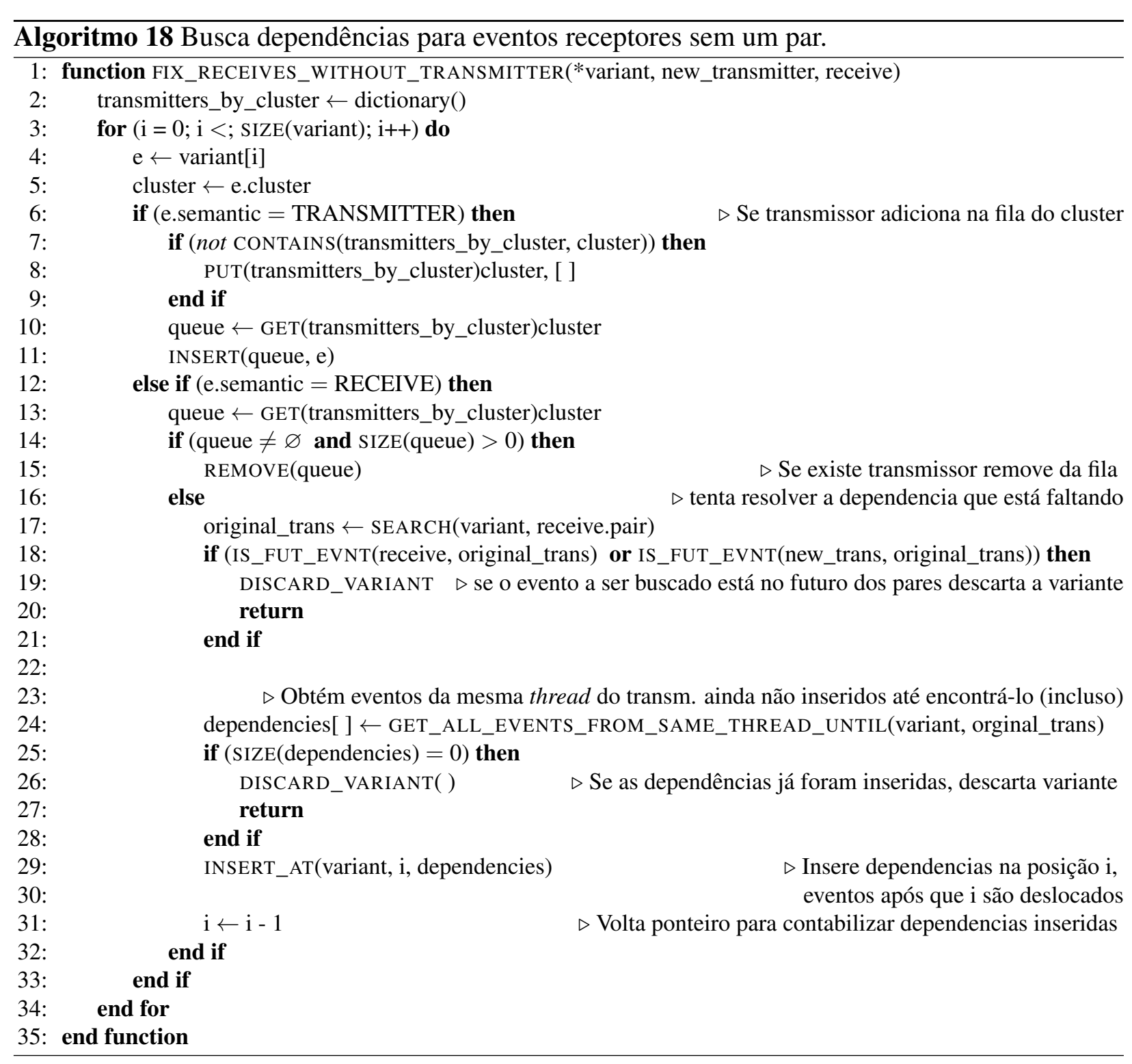

A Figura 5.3 ilustra o processo de geração de variantes como um todo. A partir de uma execução inicial que é executada livremente são coletados os arquivos de rastro que alimentam o algoritmo de geração de variantes. As variantes geradas (rastros parciais) são executadas pela execução parcialmente determinística, gerando novos arquivos de rastros. Como as variantes são derivadas a partir de informações estáticas, nem todas elas serão factíveis e, dessa forma, é definido um tempo limite parametrizado para as execuções. Este tempo é definido pelo testador. Existem três situações nas quais uma execução ultrapassa o tempo limite: (a) a variante é não executável; (b) o tempo definido não foi o suficiente para que a execução finalizasse; ou (c) um defeito foi encontrado. Os algoritmos propostos neste trabalho para a geração automática de variantes não automatizam essa análise do estouro do tempo limite. Cabe ao testador identificar estas situações.

A Figura 5.3 ilustra o processo de geração de variantes organizado em forma de árvore, na qual a partir da execução inicial (execução base ou execução zero - 0) são geradas $n$ variantes que serão executadas. Cada execução com sucesso pode gerar novas variantes até que um limite de 
cobertura estipulado seja atingido ou o número de gerações definido seja alcançado. Sempre que as execuções de uma geração são finalizadas, a cobertura das execuções que obtiveram sucesso são avaliadas e o critério de parada é verificado.

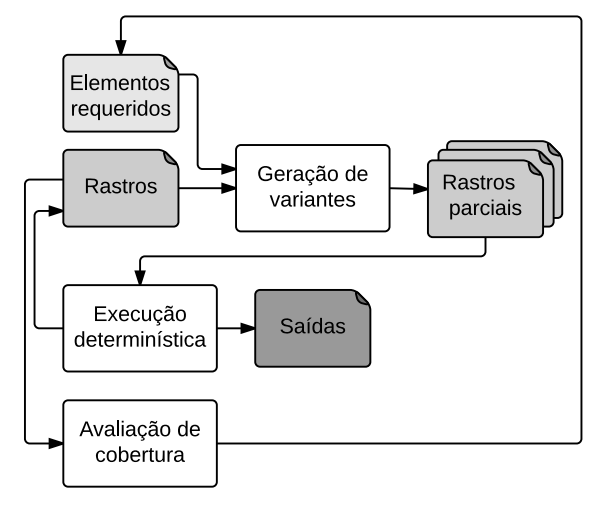

(a)

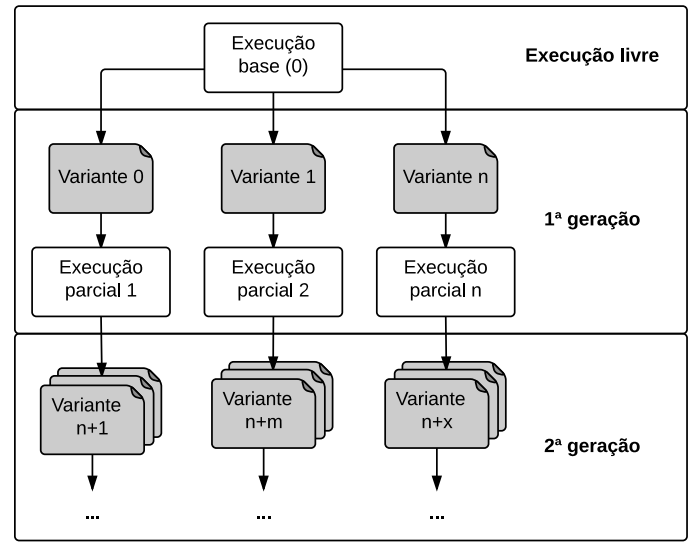

(b)

Figura 5.3: (a) Processo de geração de variantes; (b) organização das variantes.

\subsection{Avaliação e análise dos resultados}

A avaliação da geração automática de variantes foi realizada com experimentos baseados na execução de benchmarks. Os objetivos dos experimentos foram: avaliar a eficácia do algoritmo de geração de variante em aumentar o nível de cobertura do critério all-sync-edges (todas-arestassincronização) (Souza et al., 2013) e avaliar o custo/benefício das duas políticas de seleção de transmissores.

Foram selecionados sete dos nove benchmarks utilizados na avaliação do algoritmo de geração de rastro e execução determinística (Seção 4.5). São eles: passagem de mensagem bloqueante (BMP), memória compartilhada (SM), passagem de mensagem não bloqueante (NMP), produtor consumidor (PC), gerador de números primos cliente-servidor (PS), multiplicação de matrizes (MT) e token ring (TR).

Os benchmarks de primitivas coletivas todos-para-todos (ATA) e um-para-todos OTA foram desconsiderados, pois o algoritmo de geração de variantes não contempla primitivas coletivas. Estes benchmarks foram escolhidos porque possuem primitivas de passagem de mensagem bloqueante/não bloqueante e memória compartilhada. Além disto, eles apresentam um conjunto de elementos requeridos não muito extenso, o que facilita a validação dos resultados obtidos. 
Todos os benchmarks foram implementados em Java e a execução ocorreu em um computador com um processador Intel Core i - 36100M 2.3GHz com 8GB de memória em um sistema Ubuntu Server 14.04 utilizando uma Máquina Virtual Java OpenJDK 1.7.0_55.

A Tabela 5.1 apresenta a relação de elementos requeridos do critério all-sync-edges para cada um dos sete benchmarks.

Tabela 5.1: Número de elementos requeridos do critério all-sync-edges para os benchmarks utilizados.

\begin{tabular}{lcc}
\hline & Total & Factíveis \\
\hline BMP & 16 & 12 \\
SM & 20 & 12 \\
NMP & 6 & 4 \\
PC & 32 & 30 \\
PS & 79 & 70 \\
MT & 68 & 28 \\
TR & 96 & 42 \\
\hline
\end{tabular}

Os experimentos consideraram as duas políticas em relação à busca de novos transmissores: descartar um novo transmissor caso o par já tenha sido coberto; e gerar todos os pares possíveis independentemente de sua cobertura. Para cada combinação entre benchmark e política foram realizadas 60 replicações.

Este número de 60 replicações foi escolhido em função da grande variância observada nas execuções determinísticas parciais. Em cada replicação uma execução livre é realizada, na qual o algoritmo de geração de variantes irá basear-se, ou seja, uma carga aleatória é gerada para cada replicação. Portanto, dependendo da execução inicial e do progresso de cada execução, o número de variantes geradas e o nível de gerações percorridas (descida na árvore de execuções - Imagem 5.3) podem variar.

As métricas analisadas são a taxa de cobertura dos elementos all-sync-edges para avaliar a eficácia do algoritmo; o tempo da sessão de teste e a quantidade de variantes geradas para avaliar a relação custo/benefício das duas políticas para seleção de transmissores.

A Tabela 5.2 apresenta os dados dos sete benchmarks considerando a política de seleção de transmissores apenas para pares ainda não cobertos. Os dados apresentados são: tempo médio da sessão de teste, taxa média de cobertura do critério all-sync-edges (elementos cobertos / elementos factíveis), número médio de variantes executadas com sucesso (executadas com sucesso / variantes geradas) e número médio de gerações de variantes.

Cinco dos benchmarks utilizados alcançaram 100\% da taxa de cobertura em todas as execuções realizadas. Para o benchmark PC, nenhuma execução conseguiu cobrir todas as arestas de sincronização e a cobertura máxima para este benchmark foi de 90\% (27/30) sob esta política. No caso do benchmark PS, seis execuções conseguiram cobrir todas as arestas, o restante das execuções 
ficaram entre 67 e 69 arestas. No geral, a taxa de cobertura média de todos os benchmarks atingiu $97,8 \%$ das arestas de sincronização. Com exceção do benchmark MT, a quantidade de variantes geradas e que foram executadas com sucesso obteve uma taxa maior que 93\%. Nenhuma variante foi gerada para o benchmark NMP, pois com apenas a execução livre, a taxa de cobertura já chegou aos $100 \%$ das executáveis. Os benchmarks PC e PS não alcançaram 100\% de cobertura devido à limitação da política de seleção de novos transmissores discutida na Seção 5.3.

Tabela 5.2: Taxa média de cobertura e de variantes executadas com sucesso considerando a política de novos transmissores apenas para pares ainda não cobertos.

\begin{tabular}{lcccc}
\hline & Tempo da sessão $(\mathbf{m s})$ & Cobertura & Variantes com sucesso & Gerações \\
\hline BMP & 3288,50 & $12,0 / 12(100,0 \%)$ & $3,6 / 3,6(100 \%)$ & 2,00 \\
SM & 2827,92 & $12,0 / 12(100,0 \%)$ & $4,0 / 4,0(100 \%)$ & 1,00 \\
NMP & 1510,47 & $4,0 / 4(100,0 \%)$ & $0,0 / 0,0(0 \%)$ & 0,00 \\
PC & 5242,97 & $26,0 / 30(86,8 \%)$ & $5,1 / 5,2(98,1 \%)$ & 2,17 \\
PS & 89881,03 & $68,7 / 70(98,1 \%)$ & $68,5 / 73,7(93,0 \%)$ & 2,70 \\
MT & 51797,70 & $28,0 / 28(100,0 \%)$ & $4,0 / 22,0(18,2 \%)$ & 1,00 \\
TR & 16352,42 & $42,0 / 42(100,0 \%)$ & $11,8 / 11,8(100 \%)$ & 1,00 \\
\hline Média & $\mathbf{2 4 4 1 4 , 4 3}$ & $\mathbf{9 7 , 8 \%}$ & $\mathbf{7 2 , 7 6} \%$ & 1,40 \\
\hline
\end{tabular}

A Tabela 5.3 apresenta os resultados dos experimentos considerando a escolha de novos transmissores independentemente da cobertura dos elementos requeridos. Para este caso, todos os benchmarks obtiveram $100 \%$ de cobertura dos elementos requeridos executáveis all-sync-edges. A quantidade de variantes geradas para os benchmarks BMP, SM, NMP, MT e TR aumentou, porém não foi expressivo (Figura 5.4). Já os benchmarks PC e PS tiveram um grande aumento na quantidade de variantes geradas, aumentando significativamente o custo da execução das variantes. Isto ocorre pois não há um critério de seleção de caminho de pares de sincronização que considere as iterações para guiar a cobertura dos elementos requeridos.

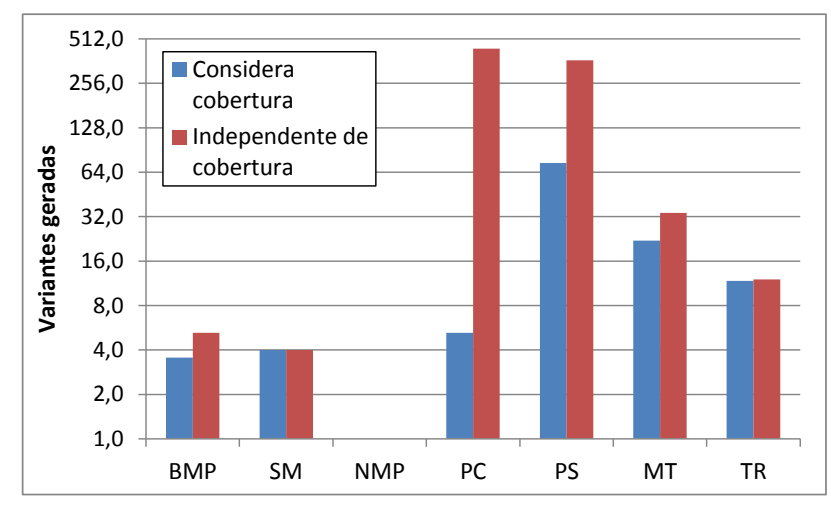

Figura 5.4: Gráfico comparativo do número de variantes geradas em relação à política de seleção de transmissores. 
Tabela 5.3: Taxa média de cobertura e de variantes executadas com sucesso considerando a política de novos transmissores independente de cobertura.

\begin{tabular}{lcccc}
\hline & Tempo da sessão $(\mathbf{m s})$ & Cobertura & Variantes com sucesso & Gerações \\
\hline BMP & 4030,03 & $12,0 / 12(100,0 \%)$ & $5,2 / 5,2(100 \%)$ & 2,00 \\
SM & 2857,20 & $12,0 / 12(100,0 \%)$ & $4,0 / 4,0(100 \%)$ & 1,00 \\
NMP & 1503,58 & $4,0 / 4(100,0 \%)$ & $0,0 / 0,0(0 \%)$ & 0,00 \\
PC & 246854,93 & $30,0 / 30(100,0 \%)$ & $419,4 / 439,6(95,4 \%)$ & 2,82 \\
PS & 421729,85 & $70 / 70(100,0 \%)$ & $335,0 / 366,3(91,5 \%)$ & 1,98 \\
MT & 75064,48 & $28,0 / 28(100,0 \%)$ & $11,2 / 34,0(32,9 \%)$ & 1,00 \\
TR & 16080,68 & $42,0 / 42(100,0 \%)$ & $12 / 12,0(100 \%)$ & 1,00 \\
\hline Média & $\mathbf{1 0 9 7 3 1 , 5 4}$ & $\mathbf{1 0 0 , 0 \%}$ & $\mathbf{7 4 , 2 6} \%$ & 2,80 \\
\hline
\end{tabular}

\subsection{Considerações finais}

Este capítulo apresentou algoritmos para a geração automática de pares de sincronização para programas concorrente com paradigmas de passagem de mensagem e memória compartilhada. Os algoritmos geram pares de sincronização a partir de uma execução não-determinística. Para cada possível par de sincronização extraído de um modelo estático são geradas novas variantes, que são prefixos a serem executados deterministicamente. Posteriormente a execução prossegue livremente, combinando assim o teste determinístico e o não-determinístico. Os algoritmos propostos são simplistas em relação à identificação de variantes infactíveis, de maneira que um tempo limite é dado para a execução de variantes.

Duas políticas para seleção de novos transmissores para formação de novos pares de sincronização foram utilizadas. Uma delas considera apenas pares cujas arestas de sincronização ainda não tenham sido cobertas, tendo como base o critério de teste estrutural all-sync-edges (Souza et al., 2013). O objetivo de usar este critério de teste como base é evitar a replicação da cobertura dos mesmos pares de sincronização. No entanto, este critério considera apenas informações estáticas do código fonte e não considera caminhos percorridos durante uma execução. Esta característica acaba por limitar a escolha de determinados pares de sincronização, os quais dependem de um caminho de execução prévio envolvendo interações específicas. Para não impor esta limitação à geração das variantes, uma segunda política de escolha de novos transmissores foi proposta, na qual são gerados pares de sincronização independentemente da cobertura. Esta última tem um custo mais elevado, porém não impede que eventos futuros sejam cobertos em uma próxima geração. Esta segunda política não força a cobertura de pares de sincronização em caminhos específicos de uma execução, porém, não impede que eles executem. Esta situação evidencia a necessidade de novos critérios de teste estrutural que permitam a geração de elementos requeridos com foco nos pares de sincronização existentes em diferentes caminhos da execução de programas concorrentes.

Os experimentos mostraram que, para os sete benchmarks utilizados, a política que não depende do critério de teste conseguiu atingir $100 \%$ de cobertura das arestas de sincronizações fac- 
tíveis e que a outra política, dependente do critério de teste estrutural all-sync-edges, obteve uma média de $97,8 \%$ de cobertura.

Estes algoritmos são importantes para garantir maior qualidade nos programas concorrentes, de forma que, quanto maior for a cobertura das arestas de sincronização maior será a probabilidade de que o programa concorrente esteja livre de defeitos de sincronização. Os algoritmos propostos automatizam um problema crônico e essencial para o teste estrutural de programas concorrentes: a execução automática de diferentes pares de sincronização com um mesmo caso de teste. Estes algoritmos são fundamentais para o testador de tais programas, tanto para simplificar a atividade de teste, quanto para aumentar a cobertura do código de uma maneira viável. Nesse sentido, uma das limitações dessa proposta é o grande número de variantes geradas que necessitam ser executadas. Tais execuções podem consumir um grande tempo de execução e, com isso, comprometer a atividade de teste. Para minimizar este problema, o próximo capítulo aborda a execução paralela das variantes. 

CAPÍTULO

\section{6}

\section{Execução Paralela da Geração} Automática de Pares de Sincronização

\subsection{Consideracões iniciais}

O teste estrutural de programas concorrentes pode facilmente tornar-se altamente custoso devido à grande quantidade de sequências de sincronização que devem ser executadas. Este capítulo apresenta uma proposta para paralelizar estas execuções, a fim de reduzir seu tempo de resposta. Uma arquitetura de software distribuída também foi desenvolvida para encapsular e modularizar os aspectos de sincronização necessários à execução paralela da ferramenta paralela de teste. Esta arquitetura é um subproduto deste trabalho e está descrita neste capítulo. A avaliação da paralelização proposta foi realizada por meio de experimentos, os quais demostram o speedup e a eficiência do algoritmo proposto. Na avaliação foram usados três benchmarks capazes que gerar uma alta demanda computacional e representar diferentes aspectos relacionados a programas concorrentes reais. Os resultados indicam que no melhor caso o algoritmo distribuído atingiu uma eficiência de $97,6 \%$ e no pior caso $66 \%$. A análise dos resultados descreve os motivos para esta variação e o impacto dos programas concorrentes testados na paralelização proposta.

\subsection{O custo do teste de programas concorrentes}

O teste de programas concorrentes tende a se tornar uma tarefa custosa conforme a complexidade e quantidade das sincronizações são agregadas a estes programas. Neste contexto, o alto custo 
está relacionado à grande quantidade de sequências de sincronizações que devem ser exercitadas para realizar a validação.

Várias técnicas vêm sendo propostas para reduzir o custo da atividade de teste, sendo que algumas reduzem também a qualidade do teste realizado. Alguns exemplos de tais propostas são: a definição de critérios de cobertura para limitar a quantidade de elementos requeridos a serem cobertos (Taylor et al., 1992; Chung et al., 1996; Yang e Pollock, 2003), a derivação de sincronizações durante tempo de execução (on-the-fly) para testar apenas sincronizações factíveis com base em um dado de teste (Hwang et al., 1995; Lei e Carver, 2006), a combinação de técnicas de análise estática do código fonte e dinâmica de arquivos de rastro (Chen et al., 2009; Souza et al., 2015), entre outras.

Apesar dos esforços em reduzir o custo do teste de programas concorrentes, quando aplicado a programas grandes e complexos, o teste pode levar muitas horas para ser realizado. Um exemplo dessa situação é apresentado durante a avaliação realizada na Seção 6.5 deste trabalho, no qual um benchmark contendo 21 threads necessita aumentar o nível de cobertura das suas arestas de sincronização. O teste sequencial para este benchmark requer em média mais de 12 horas para executar 1624 variantes de disputa (race variants) contidas apenas no primeiro nível da árvore de geração de variantes.

A computação paralela é atrativa para reduzir o tempo de resposta deste tipo de teste (Carver e Lei, 2010b). Dois trabalhos que utilizam a computação paralela para o teste de programas concorrentes são descritos em Yang et al. (Yang et al., 2007) e Carver e Lei (Carver e Lei, 2010b).

O trabalho proposto por Yang et al. (Yang et al., 2007) apresenta resultados de desempenho para uma versão distribuída da ferramenta Inspect. Inspect é uma ferramenta de verificação de modelo dinâmico (runtime model checking) capaz de exercitar todos caminhos de sincronização de programas $\mathrm{C} / \mathrm{C}++$ com $P$ Threads. Uma técnica de balanceamento dinâmico de carga é utilizada, de modo que quando um processo que está realizando as execuções (worker) se sente sobrecarregado ele envia uma mensagem para o balanceador de carga, para que a carga seja remanejada. Se o balanceador de carga encontrar um worker, seu identificador é retornado e assim a carga excedente pode ser transferida. $\mathrm{O}$ trabalho apresenta resultados próximos ao speedup linear.

Carver e Lei (Carver e Lei, 2010b) propõem uma versão distribuída da ferramenta RichTest. Ela é uma ferramenta de teste de alcançabilidade (Reachability testing) capaz de exercitar todas as sequências de sincronizações de programas concorrentes em Java e $\mathrm{C}++$, derivadas de um dado de teste e em tempo de execução. Eles utilizam uma técnica de balanceamento de carga, na qual workers ociosos solicitam mais carga ao processo mestre que são recuperadas da fila ou remanejadas de um outro worker. Um bom speedup foi alcançado pela ferramenta ficando próximo ao linear.

Não foram encontrados trabalhos que utilizem técnicas de programação concorrente para reduzir o tempo de resposta da atividade de teste estrutural para programas concorrentes. O algoritmo de distribuição apresentado neste trabalho reduz o tempo de execução para o algoritmo de geração automática de variantes apresentado no Capítulo 5. Além da paralelização, este capítulo apre- 
senta uma arquitetura de software distribuída destinada a facilitar o desenvolvimento de aplicações concorrentes em Java.

\subsection{Darch - uma arquitetura distribuída para o teste de programas concorrentes}

A Darch (Distributed ARCHtechture) é uma arquitetura de software distribuída e multiprocessada que atua como um middleware entre aplicações que interagem por passagem de mensagens na linguagem Java. A Darch representa um subproduto da paralelização da geração automática de pares de sincronização proposta neste trabalho.

A Darch encapsula as primitivas de sincronização por meio da abstração da API (Application Programming Interface) de Datagram Sockets. A Darch também fornece gerenciamento de localização possibilitando a comunicação entre duas aplicações sem a necessidade de conhecer o endereço ou a porta do host à qual a aplicação de destino está conectada. Um terceiro objetivo é a instanciação remota de aplicações com escalonamento por prioridades. O escalonamento por prioridades visa balancear a alocação das aplicações entre os hosts disponíveis onde a arquitetura é executada. O termo host está sendo usado neste trabalho como sinônimo de processador, nó ou elemento de processamento. Existem três níveis de prioridade: baixo $(L O W)$, médio (MEDIUM) e alto $(H I G H)$. Quanto maior for o nível de prioridade maior será a probabilidade da aplicação ser alocada exclusivamente em um host.

A Darch é dividida em dois módulos: aplicação e distribuição. O módulo de aplicação é uma biblioteca que facilita a comunicação com outras aplicações, tais como os módulos da ferramenta ValiPar: a ValiExec, ValiEval e ValiSync. O módulo de distribuição atua como um daemon, i.e., um processo em background responsável por gerenciar a comunicação entre as aplicações locais e aplicações remotas. Para executar uma aplicação que utiliza a arquitetura é necessário um processo do módulo de distribuição executando no host desejado e que as aplicações utilizem o módulo de aplicação para interagirem.

Ao iniciar a arquitetura, o módulo de distribuição é automaticamente criado em todos os hosts onde a aplicação será executada. A instanciação dos módulos de distribuição ocorre baseada em um arquivo de configuração.

Cada módulo é dividido em camadas que encapsulam responsabilidades e tornam a arquitetura facilmente extensível. O módulo de aplicação é dividido em duas camadas: interface de dados e comunicação.

A interface de dados permite que as mensagens enviadas sejam implicitamente transformadas para um formato que possa ser facilmente transportado de uma aplicação para outra. A este processo dá-se o nome de serialização de dados (Serialization).

A camada de comunicação é responsável pelo envio e o recebimento de mensagens. A camada possui duas filas: uma para entrada (incoming) e outra para saída (outgoing) de mensagens. Esta 
camada possui dois pools de threads, o primeiro deles é responsável pelo recebimento das mensagens e por adicioná-las à fila de entrada e o segundo é responsável por retirar as mensagens da fila de saída e enviá-las ao destinatário.

O módulo de distribuição é responsável por gerenciar a comunicação entre as aplicações locais e as aplicações remotas e também pela criação de novas aplicações locais. Este módulo é dividido em quatro camadas: comunicação, interface de dados, serviço de localização de nomes (SLN) e broker. As camadas de comunicação e de interface de dados no módulo distribuidor possuem as mesmas responsabilidades que as respectivas camadas no módulo de aplicação.

O SLN é responsável por identificar quais aplicações estão disponíveis on-line e armazenar as informações sobre suas localizações. Isto ocorre durante a inicialização do módulo de aplicação, onde uma mensagem de registro é enviada ao módulo de distribuição e os dados de identificação e localização são armazenados no SLN. Uma tabela hash distribuída (DHT - Distributed Hash Table) foi utilizada para implementar o SLN; assim, todos os endereços inseridos nesta tabela estarão disponíveis para outros módulos de distribuição. A DHT utilizada foi a OpenChord (Stoica et al., 2003), que utiliza um protocolo de busca peer-to-peer escalável, no qual a resolução de nomes é armazenada localmente em memória para agilizar as consultas.

Todas as mensagens enviadas pelas aplicações são enviadas para o módulo de distribuição local contendo o identificador da aplicação de destino. O broker é responsável pelo escalonamento destas mensagens, sendo que o mesmo possui uma fila onde são inseridas as mensagens recebidas. Conforme esta fila é consumida, o endereço de destino é resolvido por meio da consulta do identificador no SLN. As mensagens já resolvidas são enfileiradas na camada de comunicação com o endereço do destinatário.

A Figura 6.1 apresenta o fluxo do envio de uma mensagem entre duas aplicações localizadas em nós distintos, ilustrando o caminho percorrido entre os módulos da arquitetura e cada uma de suas camadas. As setas claras indicam chamadas internas do programa (métodos) e as setas escuras significam passagem de mensagens.

O processo é iniciado quando a Aplicação $\alpha$ realiza a chamada à uma primitiva de transmissão informando os dados a serem enviados e a identificação de destino (Aplicação $\beta$ ). Tais informações são encapsuladas na interface de dados e a identificação do transmissor é adicionada à mensagem, que por sua vez é enfileirada na camada de comunicação. A camada de comunicação retira a mensagem da fila e a envia para o módulo de distribuição local por meio de passagem de mensagens.

A mensagem é recebida pela camada de comunicação do módulo de distribuição, desempacotada na interface de dados e inserida na fila do broker. O broker recupera o identificador da Aplicação $\beta$ e busca seu endereço no SLN, este conhecido desde que ele recebeu informações de registro durante a inicialização da Aplicação $\beta$. O broker adiciona o endereço real da Aplicação $\beta$ na mensagem que é encapsulada novamente (interface de dados), enfileirada na camada de comunicação e posteriormente enviada para a aplicação de destino em uma passagem de mensagem. 


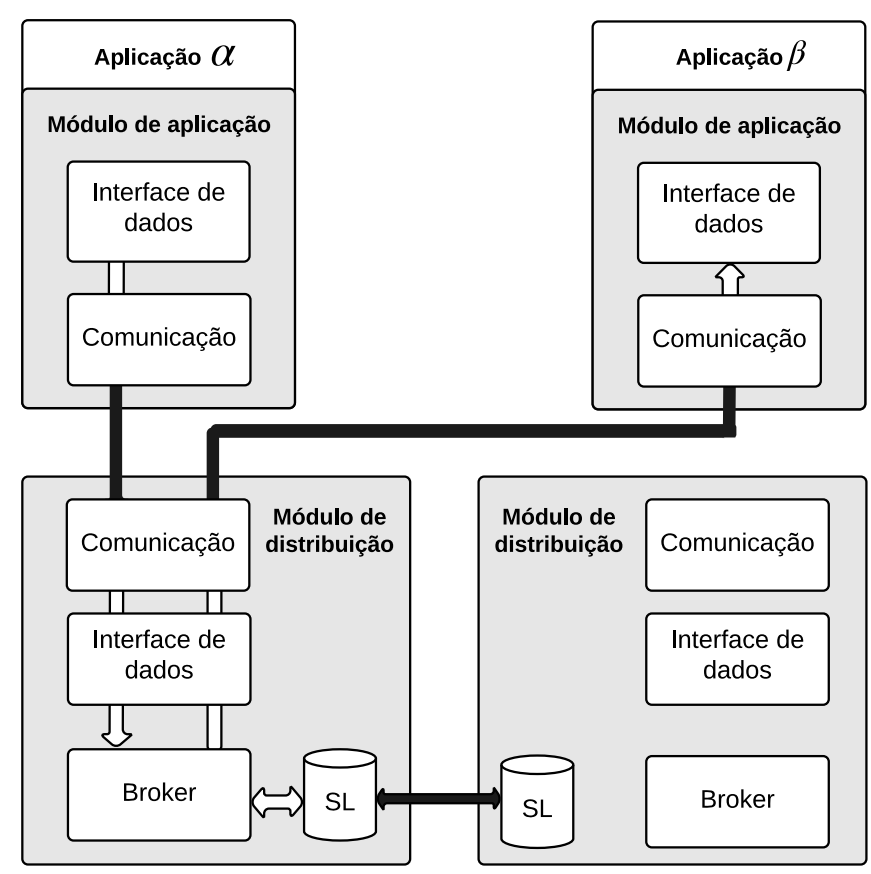

Figura 6.1: Fluxo da arquitetura durante a transmissão de uma mensagem considerando dois hosts. Cada host é delimitado nesta figura por um módulo de distribuição.

A mensagem é recebida na camada de comunicação localizada na Aplicação $\beta$, desencapsulada na interface de dados e finalmente entregue à aplicação.

Esta arquitetura encapsula os detalhes de comunicação para as aplicações, de modo que o desenvolvimento das aplicações paralelas/distribuídas (neste contexto ambas necessitam comunicar e sincronizar) possa ser facilitado. De fato, as aplicações $\alpha$ e $\beta$ podem enviar e receber informações pela arquitetura sem ter um forte acoplamento com detalhes menores dos protocolos de comunicação.

\subsection{Paralelização da geração de pares de sincronização}

O tempo de resposta da geração e da execução de todos os pares de sincronização de um programa concorrente em teste, com um dado de teste, consiste do tempo de geração das variantes, somado aos tempos de execução dessas variantes e da avaliação de cobertura de cada execução. $\mathrm{O}$ tempo para gerar as variantes consome apenas uma fração do tempo total, a avaliação de cobertura é realizada apenas para as as variantes executadas com sucesso e, no caso geral, consome um tempo menor do que a própria execução do programa. A execução do programa, contudo, é relativamente lenta, comparativamente às demais atividades e por isto ela é o foco desta paralelização. 
O algoritmo de geração e execução das variantes possui pouca ou nenhuma dependência entre as tarefas realizadas. Primeiramente, as variantes são geradas com base em uma execução não-determinística e cada uma das variantes pode ser executada em paralelo sem necessidade de nenhuma interação entre elas. Após cada execução, caso ela obtenha sucesso, é necessário avaliar as arestas de sincronização que foram cobertas. Cada execução com sucesso retroalimenta a geração de variantes até que a cobertura ou a distância limite seja alcançada (esta distância refere-se à descida na árvore, em relação à execução base inicial - execução 0). Ao final de cada nível de geração é necessário sincronizar todas as execuções para verificar estes critérios de parada.

De modo geral, a paralelização proposta distribui as variantes geradas para cada worker da ValiExec utilizado por meio de um algoritmo de escalonamento round-robin. Assim que uma execução com sucesso é finalizada a sua avaliação de cobertura é disparada para a ValiEval.

Além destas, nenhuma outra modificação é necessária nos algoritmos de geração de variantes, execução ou avaliação de cobertura. Dessa forma, foram criados wrappers para estes módulos de maneira que eles pudessem receber tarefas por meio de passagem de mensagem utilizando a Darch. Os Wrappers encapsulam os módulos e permitem que a camada envolvendo a comunicação seja adicionada sem alterar o comportamento interno de cada um deles.

Um novo módulo para orquestrar a execução paralela foi adicionado à ValiPar. Este módulo é responsável por criar remotamente os workers da ValiExec, a ValiEval e a ValiSync; por distribuir as variantes geradas pela ValiSync entre os workers da ValiExec; e por encaminhar as variantes executadas com sucesso para a ValiEval. A verificação do critério de parada também ocorre neste módulo. A descida na árvore de geração de variantes é realizada utilizando um algoritmo de busca em largura, tal como a geração de variantes sequencial. O Algoritmo 19 apresenta o pseudo-código do módulo de orquestração.

Inicialmente, as instâncias dos módulos ValiExec, ValiEval e ValiSync são criadas nos hosts remotos (Algoritmo 19.3-5). As prioridades atribuídas durante a alocação determinam que os módulos ValiSync e ValiEval devem ser alocadas no mesmo host por terem um menor peso na execução. Como as execuções das variantes consome a maior parte do tempo, múltiplas instâncias da ValiExec são criadas.

Após a criação das instâncias, todos os casos de teste são executados não-deterministicamente e a sua cobertura é avaliada (Algoritmo 19.9). Cada execução dos casos de teste é adicionada em uma fila. Esta fila possui todas as execuções que devem ser consumidas para gerar novas variantes. A retroalimentação do algoritmo ocorre inserindo novas execuções com sucesso nesta fila.

O algoritmo de geração de variantes será executado até que não haja mais execuções na fila para gerar novas variantes ou até que a cobertura ou a distância limite (em relação ao nível da árvore) seja atingida.

A primeira execução é removida da fila (Algoritmo 19.15) e uma mensagem é enviada para a ValiSync gerar as variantes para esta execução (19.16). Ao receber as variantes geradas, elas são 


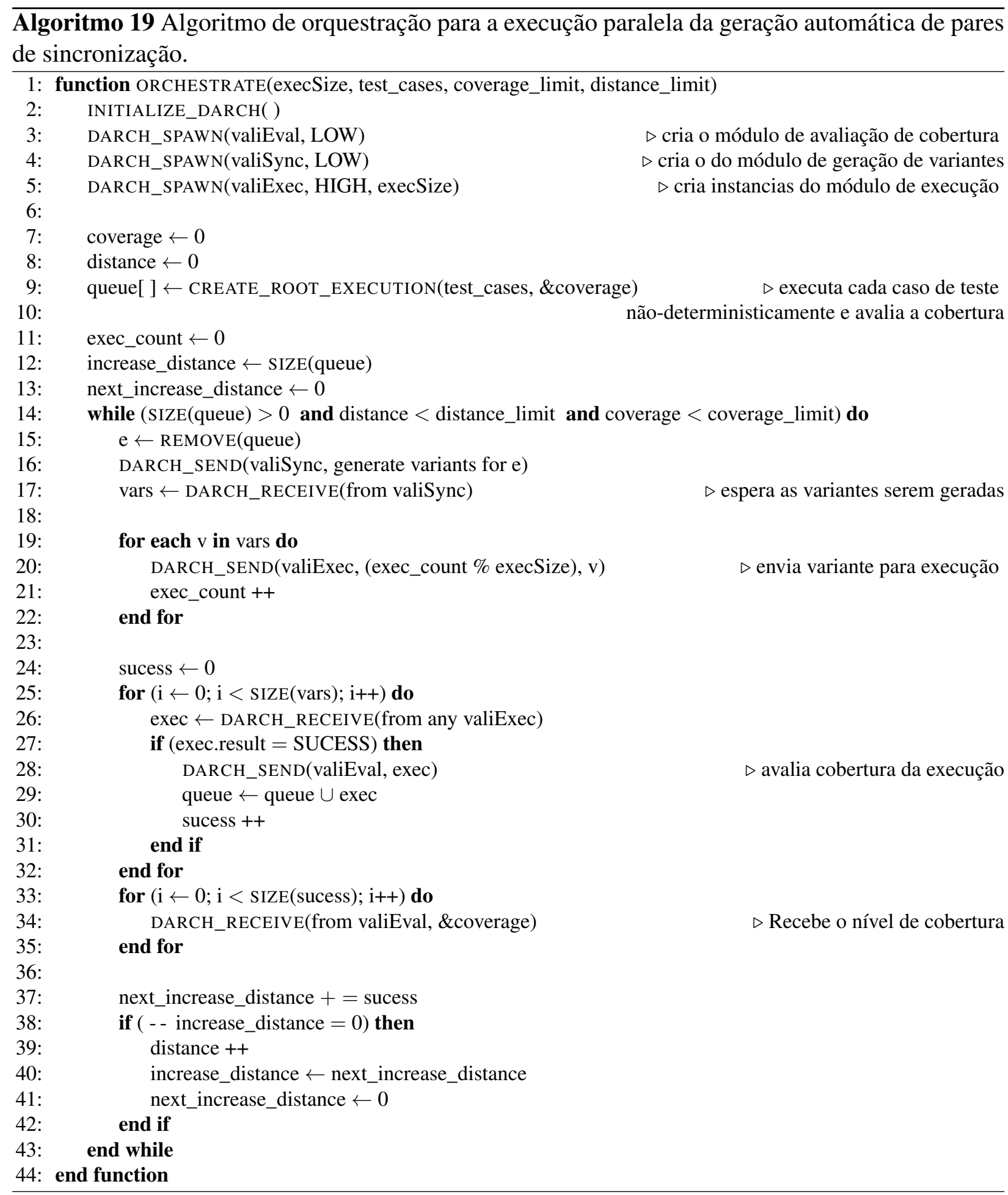

distribuídas entre os módulos de execução (ValiExec) disponíveis. A distribuição das execuções ocorre por meio do algoritmo round-robin (Algoritmo 19.20).

Para cada execução finalizada uma mensagem é enviada ao processo de orquestração contendo o resultado da execução. Caso a execução tenha ocorrido com sucesso, a execução é enviada para avaliação de cobertura e é inserida na fila para realimentar a geração de variantes (Algoritmo 19.29). 
Por fim, se não houver mais nenhuma execução no nível atual para gerar variantes a distância é incrementada.

O tempo de resposta da execução paralela das variantes apresentada neste capítulo é beneficiado em dois momentos: durante a execução simultânea das variantes do mesmo nível; e pelo pipeline gerado com a sobreposição temporal das execuções das variantes e da avaliação de cobertura. A Seção 6.5 apresenta a avaliação e os resultados obtidos da paralelização realizada.

\subsection{Experimentos e resultados}

A execução paralela das variantes proposta neste trabalho foi avaliada por meio de experimentos conduzidos no Laboratório de Sistemas Distribuídos e Programação Concorrente do ICMC/USP. O primeiro objetivo destes experimentos foi verificar se os resultados obtidos com a versão paralela estão corretos. Para esta análise foram usadas como métricas (ou variáveis de resposta) as execuções de todas as variantes esperadas e se a a taxa de cobertura da versão paralela é igual à mesma taxa da versão sequencial. O segundo objetivo dos experimentos foi verificar o comportamento do desempenho da versão paralela em relação à versão sequencial. As métricas usadas neste caso foram o Speedup (Sp) e a Eficiência (E) (Grama, 2003). O Sp e a E foram calculados em duas situações diferentes. A primeira foi em relação à execução da sessão teste, a qual envolve tanto a execução das variantes pela ValiSync quanto a posterior avaliação da cobertura pela ValiEval. Na segunda situação o $S p$ e a $E$ consideraram apenas a execução das variantes, sem considerar a análise da cobertura. Estas análises permitem comparar os ganhos de desempenho da paralelização para o usuário final (quando analisada a sessão de teste) e os ganhos de j desempenhos para a execução das variantes, foco específico da paralelização. As variáveis de reposta utilizadas para o cálculo do $S p$ e da $E$ foram o tempo de reposta da sessão de teste e o tempo de resposta das execuções das variantes.

Para ambos os objetivos foram utilizados três benchmarks: produtor-consumidor, multiplicação de matrizes e token ring. Esses benchmarks fazem parte de um conjunto maior de benchmarks desenvolvidos exclusivamente para avaliar o teste de programas concorrentes (Dourado e Souza, qualificação, 2014). Eles foram escolhidos porque apresentam as seguintes características quanto à sincronização: ponto-a-ponto, passagem de mensagem e/ou memória compartilhada e bloqueante e/ou não bloqueante. Eles também apresentam uma interação maior e são representativos no contexto de aplicações numéricas e de aplicações distribuídas que solicitam a servidores recursos/serviços os quais serão consumidos por clientes. A seguir uma breve descrição dos benchmarks é realizada:

(a) Produtor-consumidor: problema clássico da literatura que realiza 20 inserções e 20 remoções de um valor inteiro em um buffer circular de tamanho 2 protegido por 3 semáforos.

(b) Multiplicação de Matrizes $n^{3}$ multiplicações de matrizes com $n^{2}$ processos e $n^{3}$ threads. As matrizes utilizadas possuem tamanho $4 \mathrm{x} 4$ e têm os valores fixos. Cada um dos 16 processos 
escravos envia uma mensagem de registro para o processo mestre que envia uma linha da matriz A e uma coluna da matriz B que devem ser multiplicadas. Ao receber a mensagem cada processo escravo cria 4 threads que realizam as multiplicações e colocam as informações em um vetor compartilhado e protegido por um semáforo. Após as multiplicações, os processos escravos enviam uma mensagem contendo o vetor resultante para o processo mestre que monta a matriz resultante $\mathrm{C}$.

(c) Token Ring com fibonnaci: este benchmark simula uma topologia em anel, onde cada processo deve esperar sua vez para realizar a transmissão de um token (um valor inteiro qualquer) ao processo adjacente. Um processo mestre envia uma mensagem para o primeiro processo escravo que cria 4 threads. Cada thread ao ganhar acesso em um semáforo compartilhado, realiza o cálculo do fibonnaci de 39. Cada thread deve realizar a operação 9 vezes antes de passar o token para o próximo processo no anel. Este processamento repetitivo do Fibonnaci foi definido empiricamente e fornece um peso computacional às threads. O último processo escravo envia o token para o processo mestre que aguarda em um receive não-bloqueante. São realizadas 3 voltas completas no anel.

De modo a validar o número de variantes geradas/executadas, a taxa de cobertura obtida e também realizar uma comparação justa para o $S p$ e a $E$ entre a versão sequencial e a versão paralela, optou-se por fixar a execução inicial utilizada como ponto de partida para o algoritmo de geração de variantes de cada benchmark. Em outras palavras, o arquivo de rastro usado para gerar as variantes foi o mesmo tanto na versão sequencial quanto na versão paralela. Isto foi necessário, pois a execução inicial é livre e diferentes sincronizações acarretam em quantidades distintas de variantes, as quais afetam o desempenho final do teste.

A distância percorrida pelo algoritmo também foi fixada para que sejam geradas variantes somente da execução base inicial (execução 0), pois a execução de uma variante é parcialmente determinística e o restante das sincronizações podem exercitar diferentes arestas de sincronização, novamente, impactando no desempenho das execuções.

Ressalta-se também que a geração de variantes utilizada é a mesma apresentada no Capítulo 5 e que para todos os experimentos foi utilizada a política que não considera o critério de cobertura para limitar a quantidade de variantes geradas, pois esta gera um número maior de variantes e consequentemente tem um custo mais elevado.

A Tabela 6.1 contém as características resumidas dos três benchmarks. Ela apresenta para cada benchmark: a quantidade de processos, a quantidade total de threads, o número de arestas de sincronização obtidas do modelo estático, o número de variantes geradas fixando a execução inicial e o primeiro nível, quantidade de dados de teste e o tempo médio de resposta de uma execução parcialmente determinística.

Em relação ao primeiro objetivo dos experimentos, os resultados apresentados na Tabela 6.2 demonstram que a versão paralela da geração de pares de sincronização foi capaz de gerar todas as 
Tabela 6.1: Características dos benchmarks selecionados

\begin{tabular}{lcccccc}
\hline Benchmark & Proc. & Thr. & Arestas de sinc. & Var. geradas & DT & Tempo de resposta (s) \\
\hline Prod-cons & 1 & 7 & 66 & 664 & 1 & 2,66 \\
Mult. matrizes & 17 & 81 & 880 & 696 & 1 & 4,08 \\
Token Ring & 5 & 21 & 392 & 1624 & 4 & 23,17 \\
\hline
\end{tabular}

variantes geradas sequencialmente e que as taxas de cobertura foram iguais às respectivas taxas da versão sequencial. As taxas de cobertura não atingiram 100\% porque foram geradas e executadas apenas as variantes para a execução base inicial.

Tabela 6.2: Taxa de cobertura dos elementos requeridos de aresta de sincronização.

\begin{tabular}{l|cc|cc|cc}
\hline \multicolumn{4}{c}{ Prod-cons } & \multicolumn{2}{c}{ Mult.Matrizes } & \multicolumn{2}{c}{ TokenRing } \\
\hline & variantes & cobertura & variantes & cobertura & variantes & cobertura \\
\hline seq & $619 / 664$ & $62 / 66(93,9 \%)$ & $336 / 696$ & $304 / 880(34,5 \%)$ & $1396 / 1624$ & $234 / 392(59,7 \%)$ \\
$\mathbf{3}$ & $619 / 664$ & $62 / 66(93,9 \%)$ & $336 / 696$ & $304 / 880(34,5 \%)$ & $1396 / 1624$ & $234 / 392(59,7 \%)$ \\
$\mathbf{6}$ & $619 / 664$ & $62 / 66(93,9 \%)$ & $336 / 696$ & $304 / 880(34,5 \%)$ & $1396 / 1624$ & $234 / 392(59,7 \%)$ \\
$\mathbf{9}$ & $619 / 664$ & $62 / 66(93,9 \%)$ & $336 / 696$ & $304 / 880(34,5 \%)$ & $1396 / 1624$ & $234 / 392(59,7 \%)$ \\
$\mathbf{1 2}$ & $619 / 664$ & $62 / 66(93,9 \%)$ & $336 / 696$ & $304 / 880(34,5 \%)$ & $1396 / 1624$ & $234 / 392(59,7 \%)$ \\
\hline
\end{tabular}

A avaliação de desempenho feita em relação ao segundo objetivo dos experimentos segue a metodologia descrita em (Jain, 1991). Nesse contexto, os experimentos consideraram dois fatores variáveis: carga de trabalho (benchmark em teste) e a quantidade de nós.

O segundo fator, número de nós, está dividido em 5 níveis e tem por objetivo analisar o $S p$ e a $E$ da versão paralela quando diferentes nós são utilizados. Os três benchmarks foram executados sequencialmente e com 3, 6, 9 e 12 nós.

O modelo de projeto de experimentos realizado foi fatorial completo. Este modelo realiza a combinação entre todos os níveis e fatores, totalizando assim 15 experimentos.

Cada execução foi replicada dez vezes, e os resultados apresentados nesta seção representam a média aritmética destas execuções. O cálculo do intervalo de confiança realizado sobre essas medias foi baseado em uma distribuição $t$-student considerando um grau de confiança de $95 \%$. $\mathrm{O}$ intervalo de confiança se manteve pequeno para a amostra com dez repetições, ficando entre $0,88 \%$ e 4, 46\% em relação à média e sem sobreposições.

Os experimentos foram realizados em um cluster $^{1}$ do LASDPC com treze nós, e a Tabela 6.3 apresenta as suas características de hardware e software básico.

A Tabela 6.4 e a Figura 6.2 apresentam os tempos médios de resposta (em minutos) da sessão de teste para os benchmarks (a) produtor-consumidor, (b) multiplicação de matrizes e (c) token

\footnotetext{
${ }^{1}$ Não confundir o termo cluster usado aqui para determinar uma arquitetura paralela MIMD de memória distribuída, com o termo cluster usado anteriormente neste trabalho para determinar um grupo afim de primitivas de sincronização.
} 
Tabela 6.3: Características de hardware e software básico do cluster com treze nós utilizado nos experimentos.

\begin{tabular}{ll}
\hline \multicolumn{1}{c}{ Fator } & \multicolumn{1}{c}{ Valor } \\
\hline Processador host físico & Intel(R) Core(TM) i7-4790 3.60GHz \\
Memória host físico & 32 GB RAM \\
Processador host virtual & 4 Núcleos \\
Memória host virtual & 8 GB RAM \\
Virtualizador & KVM \\
Sistema Operacional & Ubuntu 14.04.1 LTS (GNU/Linux 3.13.0-44-generic x86 64) \\
Rede & Gigabit Ethernet \\
Java Runtime Edition & build 1.7.0 71b14 \\
Java Virtual Machine & Java HotSpot(TM) 64-Bit Server VM (build 24.71-b01, mixed mode) \\
\hline
\end{tabular}

ring; considerando execuções com a versão sequencial e com 3, 6, 9 e 12 nós. O intervalo de confiança também é apresentado para cada um dos experimentos.

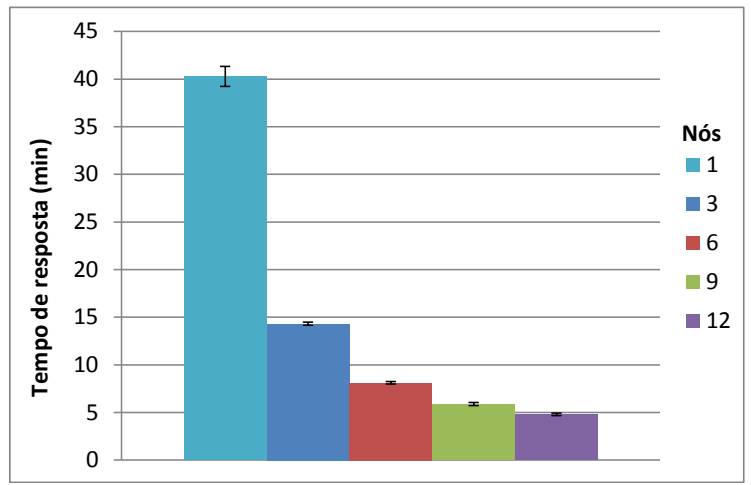

(a)

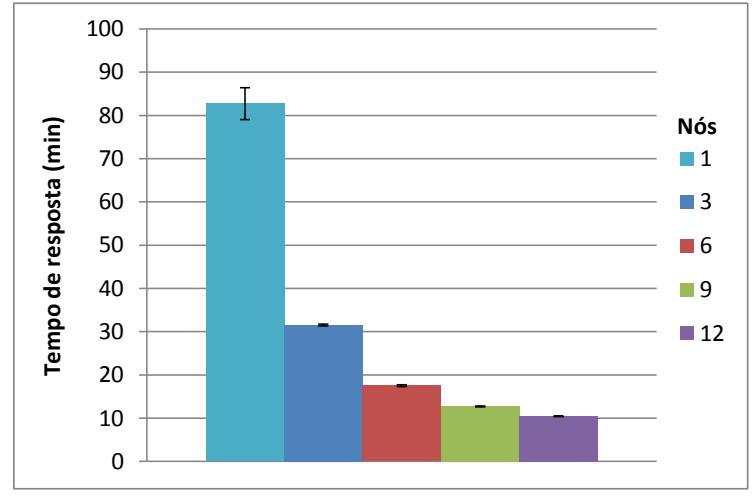

(b)

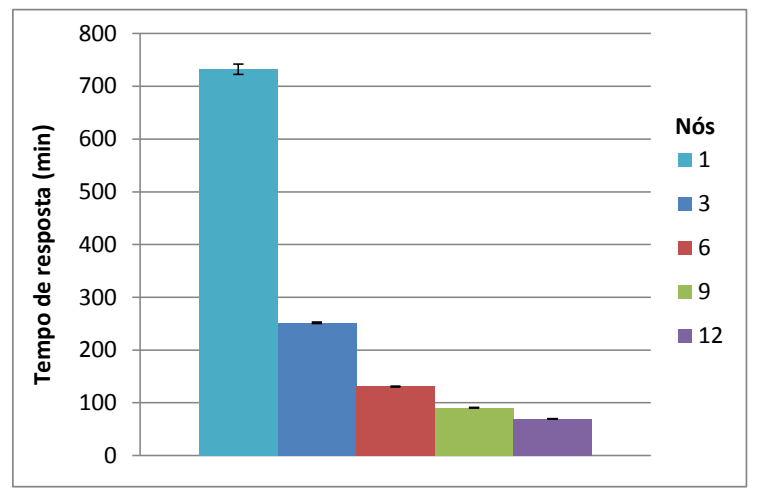

(c)

Figura 6.2: Tempo de resposta médio da sessão de teste em relação à quantidade de nós para os benchmarks: (a) produtor-consumidor; (b) multiplicação de matrizes; e (c) token ring. 
É possível observar na Tabela 6.4 e nas Figuras 6.2(a), 6.2(b) e 6.2(c) que as médias dos tempos de resposta das sessões de teste tiveram uma redução significativa. Considerando 12 hosts, quando os tempos de resposta foram menores devido ao maior número de elementos de processamento, no pior caso, a redução do tempo de resposta foi de $87,4 \%$ para a multiplicação de matrizes $(82,74$ min para 10,44 min) e, no melhor caso, essa mesma redução foi de 90,5\% para o token ring (de $732,41 \mathrm{~min}$ para $69,97 \mathrm{~min})$.

Também é possível verificar que o intervalo de confiança é pequeno e que não há sobreposições dos mesmos.

As Figuras 6.3(a) e 6.3(b) apresentam o $S p$ dos três benchmarks tanto para a sessão de teste quanto para a execução das variantes. O benchmark token ring obteve os melhores resultados ficando mais próximo ao $S p$ linear (Grama, 2003). Este $S p$ para o token ring está relacionado à grande quantidade de variantes geradas (1624), associada ao maior tempo de processamento de cada execução do benchmark (Tabela 6.1). As execuções de muitas variantes com um maior peso de processamento demoram para serem executadas sequencialmente e a versão paralela proposta neste trabalho pode otimizar esta situação.

O benchmark produtor-consumidor, apesar de ter um tempo de processamento menor (6.1), também obteve bons resultados devido à sua grande quantidade de variantes (664) e aos poucos elementos requeridos de arestas de sincronização (66), que para o token ring eram de 392 arestas. Esta quantidade menor de elementos requeridos para o produtor consumidor reduz o custo da avaliação da cobertura. A $E$ do produtor-consumidor, quando comparada à $E$ do token-ring, foi um pouco menor (uma diferença de 17,74\% no pior caso, com 12 elementos de processamento), pois o tempo de processamento das threads no produtor-consumidor é cerca de 8,7 vezes menor. Por esse motivo a paralelização para o produtor-consumidor é menos eficiente (Tabela 6.4).

Como pode ser observado na Figura 6.3(d) a $E$ da paralelização da execução das variantes para o benchmark multiplicação de matrizes foi superior a $82 \%$ até para 12 hosts, porém devido à grande quantidade de elementos requeridos de arestas de sincronização (880), neste caso a maior dentre os três benchmarks, o custo da avaliação de cobertura torna-se um fator limitante para obter um melhor $S p$, fazendo a $E$ cair para $66,03 \%$.

De uma forma geral, pode-se observar nos resultados obtidos, que o desempenho da versão paralela é melhor (quando comparada à versão sequencial) quando: (1) a aplicação concorrente apresenta um tempo de processamento maior para cada thread em relação à quantidade de interações realizadas por esta thread; (2) há uma grande quantidade de variantes geradas e que necessitam ser exercitadas; (3) há uma quantidade reduzida de elementos requeridos que precisam ser avaliados pela ValiEval ao final de cada execução.

Observando-se o $S p$ e a $E$ para a sessão de teste e para a execução das variantes de todos os benchmarks, percebe-se, como esperado, que o impacto da avaliação da cobertura feita pela ValiEval aumenta conforme o número de nós também aumenta, pois isto diminui apenas o tempo da execução das variantes. 
Observa-se também que os benchmarks produtor-consumidor e multiplicação de matrizes tiveram uma inversão na $E$ quando comparadas às execuções das variantes para 3 e 6 nós com 9 e 12 nós (vide Figura 6.3(d) e Tabelas 6.4 e 6.5). Este resultado também se deve ao peso da avaliação de cobertura que no benchmark multiplicação de matrizes é maior (880 arestas de sincronização). Assim, quando analisada apenas a $E$ da execução das variantes, esta não foi prejudicada pela porção não paralelizada da ValiEval (vide Lei de Amdahl em (Grama, 2003)).

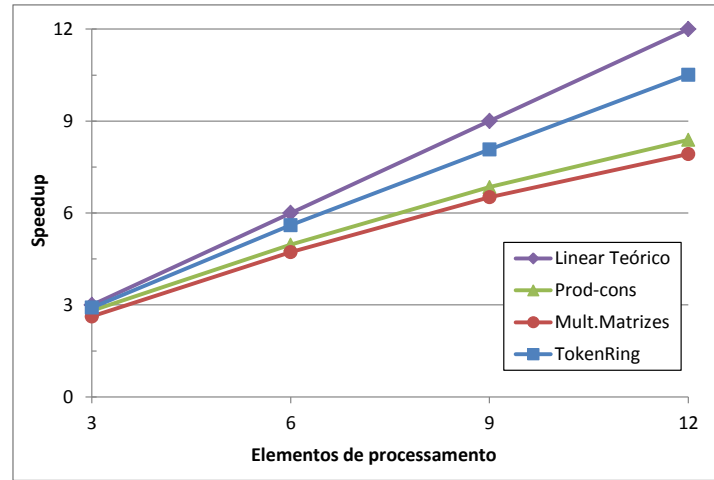

(a)

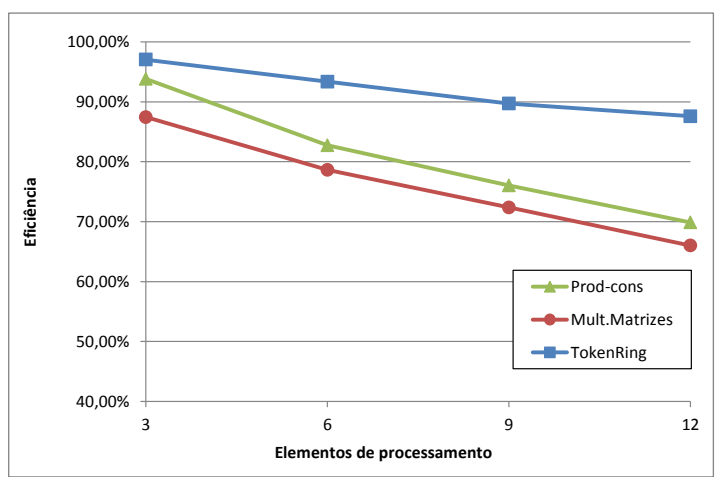

(c)

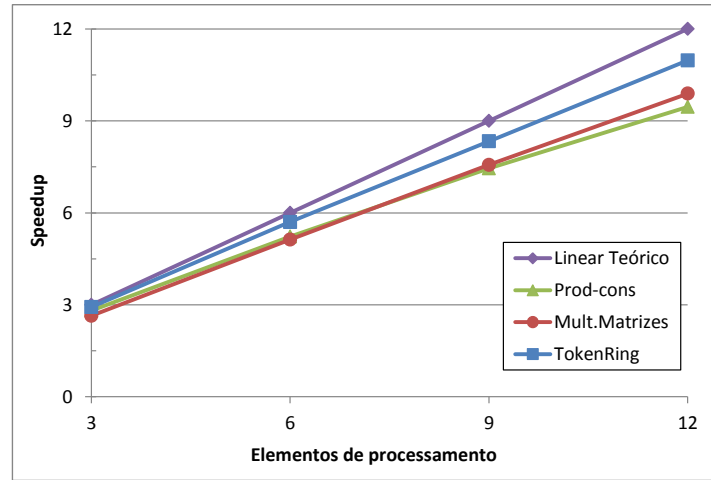

(b)

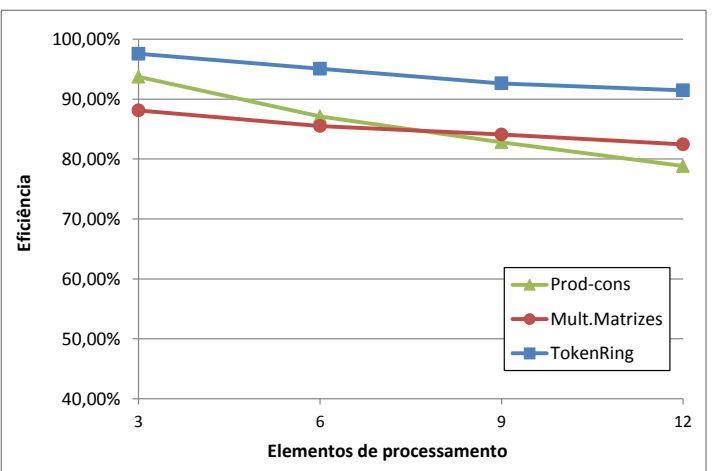

(d)

Figura 6.3: (a) $S p$ da sessão de teste; (b) $S p$ da execução das variantes; (c) $E$ da sessão de teste; (d) $E$ da execução das variantes.

Tabela 6.4: Tempo médio, speedup e $E$ da sessão de teste para os três benchmarks utilizados.

Prod-cons Mult.Matrizes

TokenRing

\begin{tabular}{c|ccc|ccc|ccc}
\hline $\mathbf{E P}$ & Média (min) & $S_{p}$ & $E_{p}$ & Média (min) & $S_{p}$ & $E_{p}$ & Média (min) & $S_{p}$ & $E_{p}$ \\
\hline $\mathbf{1}$ & 40,29 & & & 82,74 & & & 732,41 & & \\
$\mathbf{3}$ & 14,32 & 2,81 & $93,80 \%$ & 31,55 & 2,62 & $87,43 \%$ & 251,58 & 2,91 & $97,04 \%$ \\
$\mathbf{6}$ & 8,12 & 4,96 & $82,72 \%$ & 17,54 & 4,72 & $78,64 \%$ & 130,76 & 5,60 & $93,35 \%$ \\
$\mathbf{9}$ & 5,89 & 6,84 & $76,04 \%$ & 12,70 & 6,51 & $72,38 \%$ & 90,72 & 8,07 & $89,70 \%$ \\
$\mathbf{1 2}$ & 4,81 & 8,38 & $69,87 \%$ & 10,44 & 7,92 & $66,03 \%$ & 69,67 & 10,51 & $87,61 \%$ \\
\hline
\end{tabular}


Tabela 6.5: Tempo médio, speedup e $E$ da execução das variantes para os três benchmarks utilizados.

\begin{tabular}{c|ccc|ccc|ccc}
\hline & \multicolumn{3}{c}{ Prod-cons } & \multicolumn{3}{c}{ Mult.Matrizes } & \multicolumn{3}{c}{ TokenRing } \\
\hline $\mathbf{E P}$ & Média (min) & $S_{p}$ & $E_{p}$ & Média (min) & $S_{p}$ & $E_{p}$ & Média (min) & $S_{p}$ & $E_{p}$ \\
\hline $\mathbf{1}$ & 38,40 & & & 76,20 & & & 726,18 & & \\
$\mathbf{3}$ & 13,66 & 2,81 & $93,71 \%$ & 28,82 & 2,64 & $88,12 \%$ & 248,08 & 2,93 & $97,57 \%$ \\
$\mathbf{6}$ & 7,35 & 5,23 & $87,11 \%$ & 14,86 & 5,13 & $85,49 \%$ & 127,32 & 5,70 & $95,06 \%$ \\
$\mathbf{9}$ & 5,15 & 7,45 & $82,81 \%$ & 10,07 & 7,57 & $84,07 \%$ & 87,11 & 8,34 & $92,62 \%$ \\
$\mathbf{1 2}$ & 4,06 & 9,46 & $78,83 \%$ & 7,70 & 9,89 & $82,44 \%$ & 66,16 & 10,98 & $91,47 \%$ \\
\hline
\end{tabular}

\subsection{Considerações finais}

Este capítulo apresentou uma proposta de paralelização da geração e execução de pares de sincronização de programas concorrentes. Este algoritmo tem foco principal na execução das variantes que dominam majoritariamente o tempo de resposta desta atividade.

Como um subproduto desta paralelização, obteve-se a Darch, uma arquitetura de software distribuída para facilitar o desenvolvimento de aplicações Java. Tal arquitetura encapsula complexidades como localização de aplicações remotas, facilita o uso de primitivas de comunicação, realiza uma interface comum de dados entre aplicações e instancia aplicações remotamente.

Uma avaliação de desempenho foi realizada apresentando o speedup e a eficiência para três benchmarks utilizados em diferentes experimentos. A paralelização proposta apresenta excelentes resultados, principalmente para programas concorrentes com tempo de processamento alto, que gerem uma grande quantidade de variantes e que tenham um número reduzido de elementos requeridos. Para estes casos, o speedup fica bem próximo ao linear e uma eficiência superior a 97\% foi obtida no melhor caso, reduzindo o tempo de resposta de $12 \mathrm{~h}$ e $12 \mathrm{~min}$ para $1 \mathrm{~h}$ e $9 \mathrm{~min}$, aproximadamente (Token-Ring com 3 hosts). Para o pior caso a $E$ da paralelização da sessão de teste ficou em 66\% (Multiplicação de Matrizes com 12 hosts). Considerando apenas as execuções das variantes, i.e., sem considerar a avaliação da cobertura, a $E$ melhorou um pouco e foi $97,6 \%$ no melhor caso (novamente Token-Ring com 3 hosts) e 78,8\% no pior (Produtor-Consumidor com 12 hosts).

Considerando todos os experimentos, percebe-se que a pior eficiência obtida foi na paralelização da sessão de teste, para o benchmark de multiplicação de matrizes e com 12 hosts (66\%). Este resultado deve-se à grande quantidade de elementos requeridos que devem ser avaliados sequencialmente pela ValiEval para este benchmark.

Com base nessas características, propõe-se a paralelização futura do módulo de avaliação de cobertura para reduzir o tempo de resposta em programas que apresentem uma grande quantidade de elementos requeridos. Além disto, é interessante avaliar futuramente alternativas à distribuição da carga de trabalho da paralelização proposta, de modo a aplicar técnicas de balanceamento de carga dinâmicas que melhor se adaptem à realidade do programa concorrente a ser testado. 


\section{Conclusões}

\subsection{Considerações iniciais}

Este capítulo destaca as conclusões e as principais contribuições obtidas, frente aos objetivos propostos no início deste trabalho. As limitações das propostas também são discutidas e possíveis extensões para o trabalho são elencadas.

\subsection{Discussão dos resultados}

Programas concorrentes se apresentam como uma possível forma de otimização de grandes problemas computacionais permitindo soluções mais eficientes. Para isto, os desenvolvedores devem fazer uso de primitivas de sincronização, decompondo a resolução do problema em tarefas menores que possam ser executadas concorrentemente.

Apesar dos benefícios oferecidos pelos programas concorrentes, a validação, o teste e a depuração de tais programas é uma atividade difícil de ser realizada. Existem três grandes desafios da área de teste de programas concorrentes que são investigados neste trabalho.

O primeiro deles está relacionado ao não-determinismo inerente às primitivas de sincronização e ao progresso imprevisível de processos e threads. Este comportamento dificulta o processo de validação, uma vez que diferentes execuções do mesmo programa, considerando os mesmos dados de entrada, podem prosseguir por diferentes sequências de sincronização e gerar saídas corretas ou incorretas. 
Quando um defeito em uma primitiva sincronização é revelado, dificilmente ele pode ser simulado e sua correção dificilmente poderá ser validada. Isto acontece pois não há garantias que o mesmo caminho de sincronização da execução que revelou o defeito ocorrerá novamente.

Neste sentido, este trabalho apresentou no Capítulo 4 algoritmos capazes de reexecutar um programa concorrente garantindo que a mesma sequência de sincronização do programa original seja reexecutada. Durante a execução não-determinística do programa arquivos de rastro são gerados contendo informações sobre pares de sincronização e sobre a ordenação dos eventos. Estes rastros podem ser utilizados como entradas para o que o algoritmo de execução determinística fixe a ordem em que os eventos de sincronização devem ocorrer.

A execução determinística é um assunto já estudado por outros autores. No entanto, a nossa proposta diferencia-se dos demais trabalhos por permitir a reexecução de programas contendo passagem de mensagem bloqueante e não-bloqueante, memória compartilhada (semáforos) e primitivas coletivas: todos-para-todos, um-para-todos e todos-para-um. Os algoritmos também são baseados na semântica das operações proposta por Souza et al. (2008), permitindo que sejam aplicados independente de linguagem, e.g. C com PThreads/MPI ou Java. Por fim, os algoritmos aqui propostos funcionam no nível de linguagem de programação, utilizando recursos de sincronização disponíveis a qualquer desenvolvedor.

Os algoritmos propostos à execução determinística foram submetidos sistematicamente a uma avaliação contendo nove benchmarks com diversos tipos de primitivas e tamanhos. Para todos os casos os algoritmos cumpriram seus objetivos e as execuções puderam ser reexecutadas a partir dos rastros gerados. Como um fator limitador, os algoritmos para a geração de arquivo de rastro e execução determinística mostraram-se custosos em relação ao tamanho dos rastros gerados e ao aumento no tempo de resposta do programa re-executado, respectivamente. Essas sobrecargas eram esperadas e são características inerentes à atividade de teste neste contexto.

O segundo desafio que tange ao teste de programas concorrentes é executar todas as sequências de sincronização de um programa executado com um dado de teste, a fim de revelar os defeitos que podem ser omitidos pelo não determinismo. Isto é necessário, pois uma validação que não considera todos os caminhos de sincronização pode levar à falsa conclusão que o programa está livre de defeitos.

Contribuindo para a resolução deste desafio, o Capítulo 5 apresentou algoritmos capazes de explorar as diferentes sequências de sincronização de um programa concorrente. A proposta é realizada com base no teste de prefixo, utilizando uma técnica híbrida de teste determinístico e não-determinístico. O processo inicia-se com a execução não-determinística para um caso de teste e a partir do rastro desta execução, novos pares de sincronização são derivados. A execução é realizada deterministicamente até o novo par selecionado e posteriormente a execução prossegue livremente.

Para isto, a execução determinística precisou ser estendida para receber como entrada um rastro parcial e sincronizar todas as threads exatamente após o último evento controlado ter sido executado. 
Os algoritmos de seleção de pares de sincronização utilizados para explorar novas sincronizações foram projetados com base no critério all-sync-edges proposto por (Souza et al., 2013). Duas políticas de seleção de pares são apresentadas. A primeira delas gera pares apenas para arestas que ainda não tenham sido cobertas. A segunda política exercita todas as possível sincronizações independente da cobertura da aresta. Como a seleção de novos pares é baseada em um modelo estático, foi atribuído um tempo limite ajustável para a execução de cada variante. Cabe ao testador identificar variantes infactíveis.

Sete benchmarks com diferentes tamanhos e complexidades foram utilizados para avaliar o desempenho dos algoritmos de geração de variantes. A partir dos resultados obtidos, conclui-se que a primeira política de seleção gera um número menor de variantes a serem testadas, porém não garante a cobertura de todas as arestas de sincronização, alcançando em média 97,8\% de cobertura de arestas de sincronização. A segunda política, apesar de gerar quase 14 vezes mais variantes, obteve $100 \%$ de cobertura de arestas de sincronização para todos os benchmarks.

Os algoritmos para geração de variantes se diferem dos demais apresentados na literatura, pois abrangem os paradigmas de passagem de mensagem bloqueante e não bloqueante e memória compartilhada (semáforos) em um mesmo programa, no entanto, são mais simplistas no que se trata à identificação de variantes infactíveis. Apesar disto, os algoritmos demonstraram ótimos resultados cobrindo todas as arestas de sincronização executáveis.

O terceiro desafio do teste de programas concorrentes coberto neste trabalho se refere ao custo de se testar todas as sequências de sincronização. O benchmark token ring, por exemplo, leva mais de $12 \mathrm{~h}$ para executar as 1624 variantes geradas. Nesse sentido, o Capítulo 6 apresenta uma contribuição para a redução do tempo de resposta necessário para validar programas concorrentes por meio da computação paralela. $O$ foco da paralelização foi a execução das diferentes variantes geradas por meio dos algoritmos apresentados no Capítulo 5.

Três benchmarks de tamanhos distintos foram utilizados para avaliar a paralelização proposta. Os algoritmos apresentaram um desempenho próximo ao linear para um cluster com 12 hosts e para programas concorrentes com um tempo de processamento alto. Estes benchmarks tinham como principais característica a geração de uma grande quantidade de variantes e um número reduzido de elementos requeridos. No melhor caso, obteve-se uma eficiência de 97,6\% (token ring) e no pior caso a eficiência foi de $66 \%$ (multiplicação de matrizes).

Dessa forma, os algoritmos de paralelização cumprem seu objetivo em reduzir o tempo de resposta necessário para validar programas concorrentes que apresentem um tempo de processamento alto.

\subsection{Contribuições e limitações}

A seguir são apresentadas resumidamente as principais contribuições para o teste de programas concorrentes obtidas neste trabalho. 
Do ponto de vista do testador (usuário final deste trabalho), podem ser destacadas duas grandes contribuições. A primeira delas refere-se ao aumento automático da cobertura de programas concorrentes que consideram diferentes paradigmas de sincronização, esta requerida para o teste estrutural dos mesmos. Esta cobertura é usada como heurística para a revelação de defeitos ainda não descobertos no código fonte e caracteriza-se por ser uma atividade extremamente onerosa e que necessita de ferramentas de teste para ser conduzida. A segunda grande contribuição para o testador é a redução do tempo de resposta da atividade de teste estrutural de programas concorrentes utilizando a computação paralela para a execução dos diferentes pares de sincronização que necessitam ser exercitadas com um mesmo dado de teste. Esta contribuição vai ao encontro da viabilidade do teste estrutural neste contexto;

Considerando as pesquisas em teste de programas concorrentes, este trabalho contribuiu especificamente com: (1) algoritmos para a geração de arquivo de rastro e execução determinística para primitivas de passagem de mensagem ponto-a-ponto bloqueante e não-bloqueante, memória compartilhada (semáforo) e primitivas coletivas: todos-para-todos, um-para-todo e todos-para um; (2) algoritmos para a geração automática de variantes, estes capazes de alcançar uma cobertura de $100 \%$ das arestas de sincronização; (3) algoritmos paralelos para a execução de variantes no contexto do teste estrutural de programas concorrentes, os quais permitiram obter um speedup próximo ao linear e (4) a Darch, uma arquitetura distribuída e multiprocessada para facilitar o desenvolvimento de aplicações que se comunicam por passagem de mensagem na linguagem Java.

Algumas limitações foram encontradas nas propostas descritas neste trabalho. Elas são apontadas a seguir.

Os algoritmos propostos para a execução determinística possuem uma limitação relacionada à dependência cíclica de eventos reportados no rastro. A Figura 7.1 ilustra duas situações nas quais isto pode ocorrer. A primeira delas ilustrada para passagem de mensagem não-bloqueante (7.1(a)) e a segunda para a combinação entre eventos de passagem de mensagem bloquente e memória compartilhada (7.1(b)).

Os eventos representados por $t_{n}$ e $r_{n}$ simbolizam eventos de transmissão e recepção de passagem de mensagem (respectivamente) e os eventos representados por $p_{n}$ e $w_{n}$ simbolizam eventos de transmissão e recepção de memória compartilhada (respectivamente). Os números entre colchetes ao lado dos receptores $\left(r_{n}\right.$ e $\left.w_{n}\right)$ representam os relógios lógicos atribuídos aos respectivos eventos.

O diagrama espaço-tempo apresentado na Figura 7.1(a) ilustra uma situação na qual o evento transmissor $t 0$ é executado e antes que o par $t 0 \rightarrow r 0$ seja estabelecido, o receptor $r 1$ recebe a mensagem enviada por $t$. Uma situação semelhante ocorre na Figura 7.1(b), na qual o evento $w 0$ aguarda um token do evento de transmissão $p 1$, e logo após o transmissor $t 0$ enviar a mensagem e $p 1$ executar, $w 0$ adquire o relógio 0 antes que $r 0$ receba a mensagem.

A limitação referente à dependência cíclica ocorre pois o algoritmo de execução determinística assume que as mensagens são recebidas na ordem em que são enviadas (FIFO), o que para estes 
caso não é verdade. E dessa forma, os eventos $t 0$ (em ambas as figuras) seriam bloqueados esperando a liberação do seu par de sincronização ( $r 0$ - em ambas as figuras), porém os receptores $r 0$ (em ambas as figuras) devem aguardar a execução do evento $r 1$ na Figura 7.1(a) e $w 1$ na figura 7.1(b) que possuem o relógio lógico 0. Esta situação causa uma dependência cíclica dos eventos causando um deadlock.

Uma segunda limitação foi encontrada na política de seleção de transmissores que considera somente arestas ainda não cobertas durante a geração de variantes. O critério all-sync-edges não foi suficiente para guiar a seleção de algumas arestas para os benchmarks Produtor-Consumidor (PC) e Prime-Server (PS) apresentados no Capítulo 5, pois eventos de sincronização são localizados dentro de laços de repetição que não são considerados pelo critério all-sync-edges.

\subsection{Trabalhos futuros}

Com base nas conclusões obtidas deste projeto e com base nas limitações encontradas, sugerese considerar os seguintes tópicos de extensão deste projeto como trabalhos futuros:

- Estender os algoritimos de geração de rastro e execução determinística para programas C com PThreads/MPI, a fim de validar a hipótese de que os algoritmos apresentados são independentes da linguagem que os implementa;

- Realizar um estudo e a proposta de algoritmos de geração de variantes que considerem primitivas coletivas, verificando se o tipo de concorrência apresentada entre este tipo de primitivas carece de um teste exploratório tal como o já realizado para primitivas ponto-a-ponto neste trabalho;

- Criar novos critérios de teste que considerem as iterações dentro de laços de repetição para guiar a geração de variantes de disputa, cobrindo assim 100\% das arestas de sincronização, mesmo quando se considera que a política não deve exercitar arestas já cobertas. Para este trabalho, seria interessante realizar experimentos comparativos entre os dois critérios a fim de identificar o custo acrescentado;

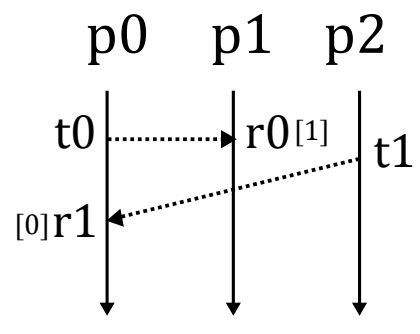

(a)

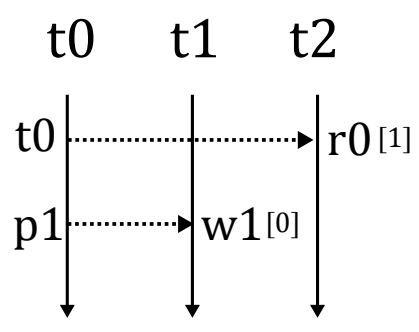

(b)

Figura 7.1: Exemplos de programas que apresentam eventos com dependência cíclica para: (a) passagem de mensagem não bloqueante; (b) combinação entre passagem de mensagem bloqueante e memória compartilhada 
- Realizar a paralelização do módulo de avaliação de cobertura a fim de otimizar ainda mais o tempo de resposta do teste estrutural e tornando o algoritmo de geração de variantes distribuído mais atrativo, mesmo para casos onde haja mais elementos requeridos do que variantes;

- Realizar estudos para a redução do tamanho dos arquivos de rastro para que programas grandes ou que contenham muitas iterações em laços de repetição possam ser testados sem comprometer a escalabilidade;

- Experimentar novas políticas de distribuição da carga de trabalho para o algoritmo paralelo de execução das variantes, tais como o modelo work-pool comentado no Capítulo 2, a fim de melhorar o balanceamento de carga entre os elementos de processamento e evitar que o processo orquestrador se torne um gargalo. 
Al-IADAn, M. A survey and a taxonomy of approaches for testing parallel and distributed programs. Proceedings ACS/IEEE International Conference on Computer Systems and Applications, p. 273-279, 2001.

Almasi, G.; Gottlieb, A. Highly parallel computing. The Benjamin/Cummings series in computer science and engineering. Benjamin/Cummings Pub. Co., 1994.

Alpern, B.; Ngo, T.; Choi, J.-D.; Sridharan, M. Dejavu: Deterministic java replay debugger for jalapeño java virtual machine. In: Addendum to the 2000 Proceedings of the Conference on Object-oriented Programming, Systems, Languages, and Applications (Addendum), OOPSLA '00, New York, NY, USA: ACM, 2000, p. 165-166 (OOPSLA '00, v.).

Ammann, P.; Offutt, J. Introduction to software testing. Cambridge University Press, 2008.

Arpaci-Dusseau, R. H.; Arpaci-Dusseau, A. C. Operating systems: Three easy pieces. 0.80 ed. Arpaci-Dusseau Books, 2014.

Bocchino, Jr., R. L.; Adve, V. S.; Dig, D.; Adve, S. V.; Heumann, S.; Komuravelli, R.; Overbey, J.; Simmons, P.; Sung, H.; Vakilian, M. A type and effect system for deterministic parallel java. SIGPLAN Not., v. 44, n. 10, p. 97-116, 2009.

CARVER, R.; LEI, Y. A class library for implementing, testing, and debugging concurrent programs. International Journal on Software Tools for Technology Transfer, v. 12, n. 1, p. 69-88, 2010a.

CARVER, R.; TAI, K. Modern multithreading: Implementing, testing, and debugging multithreaded java and $c++/$ pthreads/win32 programs. Wiley, 2005.

CARver, R.; TAI, K.-C. Replay and testing for concurrent programs. Software, IEEE, v. 8, n. 2, p. 66-74, 1991. 
CARVER, R. H.; LeI, Y. Distributed reachability testing of concurrent programs. Concurrency and Computation: Practice and Experience, v. 22, n. 18, p. 2445-2466, $2010 \mathrm{~b}$.

Chaim, M. L.; Araujo, R. P. A. An efficient bitwise algorithm for intra-procedural data-flow testing coverage. Information Processing Letters, v. 113, n. 8, p. 293 - 300, 2013.

Chen, Q.; Wang, L.; YAng, Z.; Stoller, S. D. Have: Detecting atomicity violations via integrated dynamic and static analysis. Lecture Notes in Computer Science (including subseries Lecture Notes in Artificial Intelligence and Lecture Notes in Bioinformatics), v. 5503, p. 425439, 2009.

ChOI, J.-D.; SRINIVASAN, H. Deterministic replay of java multithreaded applications. In: Proceedings of the SIGMETRICS Symposium on Parallel and Distributed Tools, SPDT '98, New York, NY, USA: ACM, 1998, p. 48-59 (SPDT'98, v.).

CHOw, T. Testing software design modeled by finite-state machines. Software Engineering, IEEE Transactions on, v. SE-4, n. 3, p. 178-187, 1978.

Christakis, M.; SAgOnAS, K. Detection of asynchronous message passing errors using static analysis. In: Proceedings of the 13th international conference on Practical aspects of declarative languages, PADL'11, Berlin, Heidelberg: Springer-Verlag, 2011, p. 5-18 (PADL'11, v.).

Chung, C.-M. C. C.-M.; Shin, T.; Wang, Y.-H. W. Y.-H.; Lin, W.-C. L. W.-C.; Kou, Y.-F. K. Y.-F. Task decomposition testing and metrics for concurrent programs. Proceedings of ISSRE '96: 7th International Symposium on Software Reliability Engineering, p. 122-130, 1996.

Cunha, J.; Kacsuk, P.; Winter, S.; Program), C. R. Parallel program development for cluster computing: Methodology, tools and integrated environments. Advances in the Theory of Computational Mathematics. Nova Science Publishers, 2001.

Delamaro, M.; Maldonado, J.; Jino, M. Introdução ao teste de software. Elsevier, 2007.

DELGAdo, S. Parallel testing techniques for optimizing test program execution and reducing test time. In: AUTOTESTCON, 2008 IEEE, 2008, p. $439-441$.

DeMillo, R.; Lipton, R.; SAYwARD, F. Hints on test data selection: Help for the practicing programmer. Computer, v. 11, n. 4, p. $34-41,1978$.

DongarRa, J.; LASTOVETSKy, A. High performance heterogeneous computing. Wiley Series on Parallel and Distributed Computing. Wiley, 2009.

Dourado, G. G. M.; SouzA, P. S. L. Contribuindo para a Avaliação do Teste de Programas Concorrentes: uma abordagem usando benchmarks. Dissertação de Mestrado, Universidade de Sao Paulo - ICMC, Sao Carlos - SP, Brasil, qualificação, 2014. 
Edelstein, O.; FArchi, E.; Nir, Y.; Ratsaby, G.; UR, S. Multithreaded java program test generation. In: Proceedings of the 2001 Joint ACM-ISCOPE Conference on Java Grande, JGI '01, New York, NY, USA: ACM, 2001, p. 181-(JGI '01, v.).

ElWAKIL, M.; YANG, Z. Deterministic replay for message-passing-based concurrent programs. ACM Trans. Des. Autom. Electron. Syst., v. 17, n. 3, p. 22:1-22:30, 2012.

Eytani, Y.; FARchi, E.; Ben-Asher, Y. Heuristics for finding concurrent bugs. In: Parallel and Distributed Processing Symposium, 2003. Proceedings. International, 2003, p. 8 pp.-.

FARChI, E.; NIR, Y.; UR, S. Concurrent bug patterns and how to test them. In: Parallel and Distributed Processing Symposium, 2003. Proceedings. International, 2003, p. 7 pp.-.

FLYNN, M. Very high-speed computing systems. Proceedings of the IEEE, v. 54, n. 12, p. 1901 $-1909,1966$.

GeBALI, F. Algorithms and parallel computing. Wiley Series on Parallel and Distributed Computing. Wiley, 2011.

Goldberg, A.; Wang, T. C.; Zimmerman, D. Applications of feasible path analysis to program testing. In: Proceedings of the 1994 ACM SIGSOFT International Symposium on Software Testing and Analysis, ISSTA '94, New York, NY, USA: ACM, 1994, p. 80-94 (ISSTA '94, v.).

GramA, A. Introduction to parallel computing. Pearson Education. Addison-Wesley, 2003.

Hausen, A. C. ValiMPI: Uma Ferramenta de Teste Estrutural para Programas Paralelos em Ambiente de Passagem de Mensagem. Masters, Universidade Federal do Paraná, Curitiba, PR, 2005.

Hsu, S.-Y.; Chung, C.-G. A heuristic approach to path selection problem in concurrent program testing. In: Distributed Computing Systems, 1992., Proceedings of the Third Workshop on Future Trends of, 1992, p. 86-92.

HuAng, J. C. An approach to program testing. ACM Comput. Surv., v. 7, n. 3, p. 113-128, 1975.

Hwang, G.-H.; TAI, K.-C.; HuAng, T.-L. Reachability Testing: An Approach to Testing Concurrent Software. International Journal of Software Engineering and Knowledge Engineering, v. 5, p. 493-510, 1995.

JAIN, R. The art of computer systems performance analysis: techniques for experimental design, measurement, simulation, and modeling. Wiley professional computing. Wiley, 1991. 
KNOLL, K. T. Risk management in fly-by-wire systems. National Aeronautics and Space Administration, Lyndon B. Johnson Space Center ; National Technical Information Service, distributor Houston, Texas : [Springfield, Va, 1 v. p., 1993.

Kojima, H.; KaKuda, Y.; TAKAhashi, J.; OHTA, T. A model for concurrent states and its coverage criteria. In: Autonomous Decentralized Systems, 2009. ISADS '09. International Symposium on, 2009, p. 1-6.

Konuru, R.; Srinivasan, H.; ChOI, J.-D. Deterministic replay of distributed java applications. In: Proceedings of the 14th International Symposium on Parallel and Distributed Processing, IPDPS '00, Washington, DC, USA: IEEE Computer Society, 2000, p. 219- (IPDPS 'O0, v.).

LAMPORT, L. Time, clocks, and the ordering of events in a distributed system. Commun. ACM, v. 21, n. 7, p. 558-565, 1978.

LEI, Y.; CARVER, R. H. Reachability testing of concurrent programs. Software Engineering, IEEE Transactions on, v. 32, n. 6, p. 382-403, 2006.

Lifflander, J.; Meneses, E.; Menon, H.; Miller, P.; Krishnamoorthy, S.; Kale, L. Scalable replay with partial-order dependencies for message-logging fault tolerance. In: Cluster Computing (CLUSTER), 2014 IEEE International Conference on, 2014, p. 19-28.

Maldonado, J. C. Critérios potenciais usos: Uma contribuição ao teste estrutural de software. Tese de Doutoramento, DCA/FEEC/UNICAMP, 1991.

McCormick, J.; Singhoff, F.; Hugues, J. Building parallel, embedded, and real-time applications with ada. Cambridge University Press, 2011.

Musuvathi, M.; QAdeer, S.; Ball, T.; Basler, G.; Nainar, P. A.; Neamtiu, I. Finding and reproducing heisenbugs in concurrent programs. In: Proceedings of the 8th USENIX Conference on Operating Systems Design and Implementation, OSDI'08, Berkeley, CA, USA: USENIX Association, 2008, p. 267-280 (OSDI'08, v.).

Olszewski, M.; Ansel, J.; Amarasinghe, S. Kendo: Efficient deterministic multithreading in software. SIGPLAN Not., v. 44, n. 3, p. 97-108, 2009.

Orso, A.; Sinha, S.; Harrold, M. Effects of pointers on data dependences. In: Program Comprehension, 2001. IWPC 2001. Proceedings. 9th International Workshop on, 2001, p. 3949.

PACHECO, P. An introduction to parallel programming. Morgan Kaufmann. Elsevier Science \& Technology, 2011. 
PACHECO, P. S. Parallel programming with mpi. San Francisco, CA, USA: Morgan Kaufmann Publishers Inc., 1996.

Prado, R. R.; Souza, P. S.; Dourado, G. G. M.; Senger, S. R. S.; Estrella, J. C.; BRUSCHI, S. M.; LOURENCO, J. Extracting static and dynamic structural information from java concurrent programs for coverage testing. Procedia Computer Science, 2015 International Conference on Computational Science, submetido, 2015.

RAPPS, S.; WeyUKer, E. J. Selecting software test data using data flow information. IEEE Trans. Softw. Eng., v. 11, n. 4, p. 367-375, 1985.

Rauber, T.; RÜnger, G.; Runger, G. Parallel programming: For multicore and cluster systems. Springer, 2010.

Sarmanho, F. S.; Souza, P. S.; SouzA, S. R.; Simão, A. S. Structural testing for semaphore-based multithread programs. In: Proceedings of the 8th international conference on Computational Science, Part I, ICCS '08, Berlin, Heidelberg: Springer-Verlag, 2008, p. 337346 (ICCS '08, v.).

SouZA, P. S.; SouZA, S. R.; ZALuskA, E. Structural testing for message-passing concurrent programs: an extended test model. Concurrency and Computation: Practice and Experience, v. 26, n. 1, p. 21-50, 2014.

Souza, P. S.; Souza, S. S.; Rocha, M. G.; Prado, R. R.; Batista, R. N. Data flow testing in concurrent programs with message passing and shared memory paradigms. Procedia Computer Science, v. 18, n. 0, p. 149 - 158, 2013 International Conference on Computational Science, 2013.

SouzA, S. R. S.; Brito, M. A. S.; Silva, R. A.; SouzA, P. S. L.; ZaluskA, E. Research in concurrent software testing: a systematic review. In: Proceedings of the Workshop on Parallel and Distributed Systems: Testing, Analysis, and Debugging, PADTAD '11, New York, NY, USA: ACM, 2011, p. 1-5 (PADTAD '11, v.).

Souza, S. R. S.; Souza, P. S. L.; Brito, M. A. S.; SimaO, A. S.; Zaluska, E. J. Empirical evaluation of a new composite approach to the coverage criteria and reachability testing of concurrent programs. Software Testing, Verification and Reliability, v. Volume 21, p. n/a-n/a, 2015.

SouzA, S. R. S.; Vergilio, S. R.; SouZA, P. S. L. Teste de programas concorrentes. In: DELAMARO, M. E.; MALDONADO, J. C.;JINO, M. Introdução ao teste de software, CAMPUS, 2007. cap.9, p. 230-250. 
Souza, S. R. S.; Vergilio, S. R.; Souza, P. S. L.; Simão, A. S.; Hausen, A. C. Structural testing criteria for message-passing parallel programs. Concurrency and Computation: Practice and Experience, v. 20, n. 16, p. 1893-1916, 2008.

Stallings, W. Computer organization and architecture: Designing for performance. Prentice Hall, 2010.

Stoica, I.; Morris, R.; Liben-nowell, D.; KARGer, D. R.; FransKaAshoek, M.; DABEK, F.; HARIBALAKRISHNAN Chord: a scalable peer-to-peer lookup protocol for internet applications. IEEE/ACM Transactions on Networking, v. 11, p. 17-32, 2003.

STOLLER, S. D. Testing concurrent java programs using randomized scheduling. Electronic Notes in Theoretical Computer Science, v. 70, n. 4, p. 142 - 157, rV'02, Runtime Verification 2002 (FLoC Satellite Event), 2002.

TAI, K.-C.; CARVER, R.; OBAID, E. Debugging concurrent ada programs by deterministic execution. Software Engineering, IEEE Transactions on, v. 17, n. 1, p. 45-63, 1991.

TAYlor, R.; LeVine, D.; Kelly, C. Structural testing of concurrent programs. Software Engineering, IEEE Transactions on, v. 18, n. 3, p. 206-215, 1992.

Trobec, R.; VAJTerŠIC, M.; Zinterhof, P. Parallel computing: Numerics, applications, and trends. Parallel Computing: Numerics, Applications, and Trends. Springer, 2009.

Weyuker, E. The cost of data flow testing: an empirical study. Software Engineering, IEEE Transactions on, v. 16, n. 2, p. 121-128, 1990.

WONG, W.; LEI, Y.; MA, X. Effective generation of test sequences for structural testing of concurrent programs. In: Engineering of Complex Computer Systems, 2005. ICECCS 2005. Proceedings. 10th IEEE International Conference on, 2005, p. 539-548.

YANG, C.-S. D.; Pollock, L. L. All-uses testing of shared memory parallel programs. Software Testing, Verification and Reliability, v. 13, n. 1, p. 3-24, 2003.

YANG, R.-D.; Chung, C.-G. A path analysis approach to concurrent program testing. In: Computers and Communications, 1990. Conference Proceedings., Ninth Annual International Phoenix Conference on, 1990, p. 425-432.

Yang, Y.; Chen, X.; Gopalakrishnan, G.; Kirby, R. Distributed dynamic partial order reduction based verification of threaded software. In: BOSNACKI, D.; EDELKAMP, S., eds. Model Checking Software, v. 4595 de Lecture Notes in Computer Science, Springer Berlin Heidelberg, p. 58-75, 2007. 